\title{
De Overijsselse arbeidsmarkt naar opleiding en beroep 2001-2006
}

Citation for published version (APA):

Borghans, L., Cörvers, F., Golsteyn, B. H. H., Hensen, M. M., \& Kriechel, B. (2003). De Overijsselse arbeidsmarkt naar opleiding en beroep 2001-2006: Statistische Bijlage. ROA. ROA Reports No. 10B https://doi.org/10.26481/umarep.200310B

Document status and date:

Published: 01/01/2003

DOI:

10.26481/umarep.200310B

Document Version:

Publisher's PDF, also known as Version of record

\section{Please check the document version of this publication:}

- A submitted manuscript is the version of the article upon submission and before peer-review. There can be important differences between the submitted version and the official published version of record.

People interested in the research are advised to contact the author for the final version of the publication, or visit the DOI to the publisher's website.

- The final author version and the galley proof are versions of the publication after peer review.

- The final published version features the final layout of the paper including the volume, issue and page numbers.

Link to publication

\footnotetext{
General rights rights.

- You may freely distribute the URL identifying the publication in the public portal. please follow below link for the End User Agreement:

www.umlib.nl/taverne-license

Take down policy

If you believe that this document breaches copyright please contact us at:

repository@maastrichtuniversity.nl

providing details and we will investigate your claim.
}

Copyright and moral rights for the publications made accessible in the public portal are retained by the authors and/or other copyright owners and it is a condition of accessing publications that users recognise and abide by the legal requirements associated with these

- Users may download and print one copy of any publication from the public portal for the purpose of private study or research.

- You may not further distribute the material or use it for any profit-making activity or commercial gain

If the publication is distributed under the terms of Article $25 \mathrm{fa}$ of the Dutch Copyright Act, indicated by the "Taverne" license above, 


\section{Statistische Bijlage \\ De Overijsselse arbeidsmarkt naar opleiding en beroep \\ 2001-2006}

ROA-R-2003/10B

Researchcentrum voor Onderwijs en Arbeidsmarkt

Faculteit der Economische Wetenschappen en Bedrijfskunde Universiteit Maastricht

Maastricht, september 2003 
Niets uit deze uitgave mag worden verveelvoudigd en/of openbaar gemaakt door middel van druk, fotokopie, microfilm, of op welke wijze ook, zonder voorafgaande schriftelijke toestemming van de directeur van het Researchcentrum voor Onderwijs en Arbeidsmarkt. In geval van overname van het datamateriaal moet telkens als bron worden vermeld: "Researchcentrum voor Onderwijs en Arbeidsmarkt" of "ROA". Van publicaties waarin gebruik wordt gemaakt van gegevens uit dit rapport ontvangen wij gaarne een exemplaar.

Hoewel de grootst mogelijke zorg is besteed aan de inhoud van dit rapport, kan het ROA in generlei opzicht verantwoordelijkheid op zich nemen voor eventuele onvolledigheden of onjuistheden.

ISBN 90-5321-374-0

Sec03.034 


\section{Inhoud}

1 De werkgelegenheidstructuur in Overijssel

Tabel 1.1 Aantal werkenden per bedrijfssector, Overijssel, gemiddelde 2000-2001

Tabel 1.2 Belangrijkste opleidingsniveaus van de werkenden per bedrijfssector, Overijssel, gemiddelde 2000-2001

Tabel 1.3 Percentage jongeren (15-29 jaar) per bedrijfssector, Overijssel, gemiddelde 2000-2001

Tabel 1.4 Percentage ouderen (50-64 jaar) per bedrijfssector, Overijssel, gemiddelde 2000-2001

Tabel 1.5 Percentage vrouwen per bedrijfssector, Overijssel, gemiddelde 2000-2001

Tabel 1.6 Percentage flexibel werk per bedrijfssector, Overijssel, gemiddelde 2000-2001

Tabel 1.7 Percentage deeltijdwerk per bedrijfssector, Overijssel, gemiddelde 2000-2001

Tabel 1.8 Percentage zelfstandigen per bedrijfssector, Overijssel, gemiddelde 2000-2001

Tabel 1.9 Aantal werkenden per beroepssegment, Overijssel, gemiddelde 2000-2001

Tabel 1.10 Percentage jongeren (15-29 jaar) per beroepssegment, Overijssel, gemiddelde 2000-2001

Tabel 1.11 Percentage ouderen (50-64 jaar) per beroepssegment, Overijssel, gemiddelde 2000-2001

Tabel 1.12 Percentage vrouwen per beroepssegment, Overijssel, gemiddelde 2000-2001

Tabel 1.13 Percentage flexibel werk per beroepssegment, Overijssel, gemiddelde 2000-2001

Tabel 1.14 Percentage deeltijdwerk per beroepssegment, Overijssel, gemiddelde 2000-2001

Tabel 1.15 Percentage zelfstandigen per beroepssegment, Overijssel, gemiddelde 2000-2001

Tabel 1.16 Aantal werkenden per opleidingstype, Overijssel, gemiddelde 2000-2001

Tabel 1.17 Arbeidsmarktpositie potentiële beroepsbevolking naar opleidingstype, Overijssel, gemiddelde 2000-2001

Tabel 1.18 Percentage jongeren (15-29 jaar) per opleidingssector, Overijssel, gemiddelde 2000-2001

Tabel 1.19 Percentage ouderen (50-64) per opleidingssector, Overijssel, gemiddelde 2000-2001

Tabel 1.20 Percentage vrouwen per opleidingssector, Overijssel, gemiddelde 2000-2001

Tabel 1.21 Percentage flexibel werk per opleidingssector, Overijssel, gemiddelde 2000-2001 
Tabel 1.22 Percentage deeltijdwerk per opleidingssector, Overijssel, gemiddelde 2000-2001

Tabel 1.23 Percentage zelfstandigen per opleidingssector, Overijssel, gemiddelde 2000-2001

2 Leerlingen en gediplomeerden in Overijssel

Tabel 2.1 Aantal leerlingen in het VMBO en MBO per opleidingstype, Overijssel, 2000 en 2001

Tabel 2.2 Aantal leerlingen (BBL) in het MBO per opleidingstype, Overijssel, 2000 en 2001

Tabel 2.3 Aantal leerlingen (BOL) in het MBO per opleidingstype, Overijssel, 2000 en 2001

Tabel 2.4 Percentage vrouwelijke leerlingen in het VMBO en MBO per opleidingstype, Overijssel, 2000 en 2001

Tabel 2.5 Aantal gediplomeerden in het VMBO en MBO per opleidingstype, Overijssel, 2000 en 2001

Tabel 2.6 Aantal gediplomeerden (BBL) in het MBO per opleidingstype, Overijssel 2000 en 2001

Tabel 2.7 Aantal gediplomeerden (BOL) in het MBO per opleidingstype, Overijssel 2000 en 2001

Tabel 2.8 Percentage vrouwelijke gediplomeerden in het VMBO en MBO per opleidingstype, Overijssel, 2000 en 2001

3 Actuele discrepanties op de Overijsselse arbeidsmarkt

Tabel 3.1 Openstaande vacatures per bedrijfssector, Overijssel, april 2003

Tabel 3.2 Openstaande vacatures per beroepssegment, Overijssel, april 2003

Tabel 3.3 Niet-werkende werkzoekenden per beroepssegment, Overijssel, april 2003

Tabel 3.4 Niet-werkende werkzoekenden per beroepssegment en bemiddelingsfase, Overijssel, april 2003

Tabel 3.5 Kenmerken niet-werkende werkzoekenden per beroepssegment, Overijssel, april 2003

Tabel 3.6 Discrepanties per bedrijfssector, Overijssel, april 2003

Tabel 3.7 Discrepanties per beroepssegment, Overijssel, april 2003

Tabel 3.8 Werkloosheid (in procenten) onder MBO-schoolverlaters per opleidingssector, Overijssel en Nederland, 2002

Tabel 3.9 Intredewerkloosheid (langer dan 4 maanden, in procenten) onder MBO-schoolverlaters per opleidingssector, Overijssel en Nederland, 2002

Tabel 3.10 Gemiddeld bruto maandloon (in euro's) onder MBOschoolverlaters per opleidingssector, Overijssel en Nederland, 2002

Tabel 3.11 Percentage MBO-schoolverlaters met een flexibele aanstelling per opleidingssector, Overijssel en Nederland, 2002

Tabel 3.12 Percentage MBO-schoolverlaters dat in deeltijd (12 tot 32 uur per week) werkt per opleidingssector, Overijssel en Nederland, 2002

Tabel 3.13 Onderbenutting van MBO-schoolverlaters per opleidingssector, Overijssel en Nederland, 2002 
Tabel 3.14 Percentage MBO-schoolverlaters dat buiten de eigen vakrichting werkzaam is, per opleidingssector, Overijssel en Nederland, 2002

4 De Overijsselse arbeidsmarkt in 2004

Tabel 4.1 Verwachte uitbreidingsvraag per bedrijfssector (als percentage van de werkgelegenheid), Overijssel, 2004

Tabel 4.2 Verwachte uitbreidingsvraag per beroepsgroep (als percentage van de werkgelegenheid), Overijssel, 2004

Tabel 4.3 Verwachte vervangingsvraag per beroepsgroep (als percentage van de werkgelegenheid), Overijssel, 2004

Tabel 4.4 Verwachte baanopeningen per beroepsgroep (als percentage van de werkgelegenheid), Overijssel, 2004

Tabel 4.5 Indicator Toekomstige Knelpunten in de personeelsvoorziening per Beroep (ITKB) per beroepsgroep, Overijssel, 2004 (alleen elementaire, lagere en middelbare beroepen)

Tabel 4.6 Verwachte uitbreidingsvraag per opleidingstype (als percentage van de werkgelegenheid), Overijssel, 2004

Tabel 4.7 Verwachte vervangingsvraag per opleidingstype (als percentage van de werkgelegenheid), Overijssel, 2004

Tabel 4.8 Verwachte baanopeningen per opleidingstype (als percentage van de werkgelegenheid), Overijssel, 2004

Tabel 4.9 Verwachte arbeidsmarktinstroom van schoolverlaters per opleidingstype (als percentage van de werkgelegenheid), Overijssel, 2004 (alleen lagere en middelbare opleidingen)

Tabel 4.10 Indicator Toekomstperspectieven op de Arbeidsmarkt voor schoolverlaters (ITA) en Indicator Toekomstige knelpunten in de Personeelsvoorziening (ITKP) per opleidingstype, Overijssel, 2004 (alleen lagere en middelbare opleidingen)

\section{De Overijsselse arbeidsmarkt tot 2006}

Tabel 5.1 Verwachte uitbreidingsvraag per bedrijfssector (als percentage van de werkgelegenheid), Overijssel, 2001-2006

Tabel 5.2 Verwachte uitbreidingsvraag per beroepsgroep (als percentage van de werkgelegenheid), Overijssel, 2001-2006

Tabel 5.3 Verwachte vervangingsvraag per beroepsgroep (als percentage van de werkgelegenheid), Overijssel, 2001-2006

Tabel 5.4 Verwachte baanopeningen per beroepsgroep (als percentage van de werkgelegenheid), Overijssel, 2001-2006

Tabel 5.5 Indicator Toekomstige knelpunten in de personeelsvoorziening per Beroep (ITKB) per beroepsgroep, Overijssel, 2001-2006 (alleen elementaire, lagere en middelbare beroepen)

Tabel 5.6 Verwachte uitbreidingsvraag per opleidingstype (als percentage van de werkgelegenheid), Overijssel, 2001-2006

Tabel 5.7 Verwachte vervangingsvraag per opleidingstype (als percentage van de werkgelegenheid), Overijssel, 2001-2006

Tabel 5.8 Verwachte baanopeningen per opleidingstype (als percentage van de werkgelegenheid), Overijssel, 2001-2006

Tabel 5.9 Verwachte arbeidsmarktinstroom van schoolverlaters per opleidingstype (als percentage van de werkgelegenheid), Overijssel, 2001-2006 (alleen lagere en middelbare opleidingen) 
Tabel 5.10 Indicator Toekomstperspectieven op de arbeidsmarkt voor schoolverlaters (ITA) en Indicator Toekomstige Knelpunten in de Personeelsvoorziening (ITKP) per opleidingstype, Overijssel, 2001-2006 (alleen lagere en middelbare opleidingen)

Tabel 5.11 Conjunctuurgevoeligheid per opleidingstype

Tabel 5.12 Uitwijkmogelijkheden naar verschillende beroepsgroepen per opleidingstype, Overijssel, gemiddelde 2000-2001

Tabel 5.13 Substitutiemogelijkheden tussen mensen met uiteenlopende opleidingsachtergronden per beroepsgroep, Overijssel, gemiddelde 2000-2001

\section{Classificaties}

Overzicht van opleidingstypen

Beroepsgroepen, volgorde ROA

Beroepsgroepen, volgens SBC '92

Beknopte Bedrijfsclassificatie SBI '93 


\section{Voorwoord}

Deze Statistische Bijlage bij het rapport De Overijsselse arbeidsmarkt 2001-2006 geeft een systematisch overzicht van de verwachte arbeidsmarktontwikkelingen en de actuele arbeidsmarktgegevens die ten grondslag liggen aan het hoofdrapport. Op basis van de in het kader van het project Regionale ArbeidsMarkT Informatiesysteem Overijssel (RATIO) gegenereerde en verzamelde kwantitatieve informatie wordt een zo volledig mogelijk beeld gegeven, verbijzonderd naar 13 bedrijfssectoren, 127 beroepsgroepen en 113 opleidingstypen. Het doel van RATIO is het ontwikkelen en actualiseren van een informatiesysteem dat een breed overzicht geeft van de huidige arbeidsmarktsituatie en de toekomstige arbeidsmarktontwikkelingen in de provincie Overijssel en de twee onderscheiden RPA-rayons (Regionale Platforms Arbeidsmarkt) IJssel Vecht en Twente. Uit dit overzicht komen de huidige en toekomstige discrepanties naar beroep en opleiding naar voren. Op basis van het informatiesysteem van RATIO kan door de provincie Overijssel en de verschillende arbeidsmarktparticipanten in de provincie beleid geformuleerd en uitgevoerd worden. Bovendien kan de informatie gebruikt worden in het kader van de studie- en beroepskeuzevoorlichting, bijvoorbeeld voor jongeren die hun opleidingskeuze moeten bepalen. Het hoofdrapport De Overijsselse arbeidsmarkt 2001-2006 geeft het kader aan waarin de tabellen in deze Statistische Bijlage moeten worden geplaatst. Voor de gebruikte terminologie wordt verwezen naar de Verklarende woordenlijst achter in het hoofdrapport.

Deze Statistische Bijlage bestaat uit vijf delen. In de eerste drie delen staat de actuele arbeidsmarktsituatie centraal. In het eerste deel wordt een beeld geschetst van de werkgelegenheidsstructuur in de provincie Overijssel. Er wordt achtereenvolgens informatie gepresenteerd over de persoons- en functiekenmerken van de werkzame beroepsbevolking in Overijssel naar bedrijfssector, beroepsgroep en opleidingstype (dan wel beroepssegment en opleidingssector). Hierbij wordt telkens ook een vergelijking gemaakt met het landelijke beeld. De arbeidsmarktgegevens met betrekking tot de werkzame en niet-werkzame bevolking in het eerste deel zijn afkomstig uit de Enquête Beroepsbevolking (EBB) van het Centraal Bureau voor de Statistiek (CBS).

Het tweede deel bevat gegevens over het aantal leerlingen en gediplomeerden in het voorbereidend en middelbaar beroepsonderwijs (VMBO en $\mathrm{MBO}$ ). Hiermee wordt een indruk verkregen van het potentiële actuele en toekomstige aanbod van schoolverlaters op de Overijsselse arbeidsmarkt. Van belang is echter op te merken dat een aanzienlijk deel van de schoolverlaters doorstroomt binnen de beroepskolom. De gegevens hebben betrekking op de kalenderjaren 2000 en 2001 en zijn uitgesplitst naar opleidingstype en geslacht. Bovendien zijn de aantallen leerlingen en gediplomeerden van het MBO uitgesplitst naar beroepsopleidende $(B O L)$ en beroepsbegeleidende leerweg (BBL). De gegevens zijn gebaseerd op de aanlevering door de Overijsselse ROC's en AOC in het kader van de Bekostigingstellingen van de Centrale Financiën Instellingen (Cfi) voor het Ministerie van OCenW en de Landbouwtellingen ${ }^{1}$ van STOAS voor het Ministerie van LNV.

In het derde deel staan de actuele discrepanties tussen vraag en aanbod op de arbeidsmarkt, alsmede de actuele arbeidsmarktsituatie van de $\mathrm{MBO}$-schoolverlaters centraal. In dit derde deel wordt eerst aandacht geschonken aan de openstaande vacatures naar bedrijfssector en beroepssegment. Hierbij wordt niet alleen het aantal openstaande vacatures weergeven, maar ook de vacaturegraad en het percentage langdurig openstaande vacatures. Tevens wordt er informatie gepresenteerd over het aantal niet-werkende werkzoekenden en hun achtergrondkenmerken naar geslacht, leeftijd, zoekduur en bemiddelbaarheid. Verder wordt er informatie gegeven over de verhouding tussen vacatures en werkzoekenden (fase 1 en fase 2/3) per

1. Opgemerkt dient te worden dat de gegevens van de gediplomeerden in de landbouwopleidingen van het VMBO en het MBO in het kalenderjaar 2000 alleen betrekking hebben op de gediplomeerden die niet in het onderwijs doorstromen. 
bedrijfssector en beroepssegment. In aansluiting hierop worden de aantallen openstaande vacatures en niet-werkende werkzoekenden met elkaar geconfronteerd. Dit maakt het mogelijk de kwantitatieve en kwalitatieve discrepanties op de Overijsselse arbeidsmarkt in beeld te brengen. Hiervoor worden twee indicatoren gepresenteerd. De indicator voor de arbeidsmarktkrapte naar bedrijfssector, beroepssegment of opleidingssector geeft de verhouding weer tussen het aantal openstaande vacatures en het aantal direct bemiddelbare werkzoekenden (fase 1). Wanneer de indicator voor de arbeidsmarktkrapte groter is dan één, is er sprake van een tekort. Wanneer de indicator daarentegen kleiner is dan één, dan is er sprake van (enige) ruimte op het desbetreffende arbeidsmarktsegment. De knelpuntindicator geeft aan in hoeverre een tekort aan direct-inzetbaar aanbod een kwantitatief of een kwalitatief karakter heeft. De indicator geeft de verhouding weer tussen enerzijds het aantal openstaande vacatures dat niet door direct inzetbare werkzoekenden kan worden opgevuld en anderzijds het aantal niet-werkende werkzoekenden met een wat grotere afstand tot de arbeidsmarkt. Naarmate deze verhouding groter wordt, heeft het tekort een meer kwantitatief karakter. Het aantal niet-werkende werkzoekenden schiet in dit geval eenvoudigweg tekort om aan de openstaande vraag te voldoen. De gegevens over vacatures en niet-werkende werkzoekenden zijn afkomstig van het Centrum voor Werk en Inkomen (CWI Oost-Nederland). De informatie per opleidingssector kon door omstandigheden niet door het Centrum voor Werk en Inkomen worden samengesteld. Het derde deel eindigt met informatie over de actuele arbeidsmarktpositie van MBO-schoolverlaters op de Overijsselse arbeidsmarkt en is gebaseerd op gegevens uit het Schoolverlaters Informatie Systeem (SIS) van het ROA. Deze informatie geeft niet alleen de werkloosheid weer, maar ook bijvoorbeeld de mate waarin schoolverlaters onder hun niveau of buiten hun vakrichting werken. Daarbij wordt per opleidingssector een vergelijking gemaakt met de landelijke arbeidsmarktpositie van MBO-schoolverlaters.

De in de delen vier en vijf gepresenteerde tabellen geven een beeld van de te verwachten toekomstige ontwikkelingen op de Overijsselse arbeidsmarkt naar beroepsgroep en opleidingstype. In deel vier worden de prognoses voor de korte termijn (d.w.z. voor 2004) gepresenteerd, terwijl in deel vijf een overzicht wordt gegeven van de prognoses voor de middellange termijn (de periode 2001-2006). De prognoses binnen RATIO zijn (deels) gebaseerd op de uitkomsten van het landelijke model waarvan de uitkomsten door het ROA zijn gepresenteerd in De arbeidsmarkt naar opleiding en beroep tot 2006 (ROA-R-2001/8). Het Etil heeft de prognoses voor de werkgelegenheidsgroei per bedrijfssector aan het ROA geleverd. Bij het samenstellen van deze prognoses door Etil is mede gebruik gemaakt van de op dit moment meest recente sectorprognoses uit het Centraal Economisch Plan (CEP, april 2003) van het Centraal Planbureau.

De gepresenteerde prognoses hebben zowel betrekking op de vraagzijde als op de aanbodzijde van de arbeidsmarkt. Aan de vraagzijde van de arbeidsmarkt wordt een onderscheid gemaakt tussen de uitbreidingsvraag en de vervangingsvraag, die tezamen de baanopeningen voor nieuwkomers op de arbeidsmarkt vormen. De Indicator Toekomstige Arbeidsmarktperspectieven (ITA) geeft de verhouding tussen vraag en aanbod per opleidingstype weer. Daarbij moet worden bedacht dat een aanbodoverschot van mensen met een bepaalde opleidingsachtergrond of beroep niet per se tot werkloosheid van de betrokkenen hoeft te leiden. Een gebrekkige aansluiting tussen vraag en aanbod kan zich ook manifesteren in een hogere kans op werk buiten het eigen vakgebied of beneden het gevolgde opleidingsniveau, een lagere beloning, een grotere kans op een tijdelijk contract, etc. De Indicator Toekomstige Knelpunten in de Personeelsvoorziening (ITKP) en de Indicator Toekomstige Knelpunten in de Personeelsvoorziening naar Beroep (ITKB) bezien de implicaties van de verhouding tussen vraag en aanbod vanuit het gezichtspunt van de werkgever. Ook hierbij moet bedacht worden dat een aanbodtekort niet per se tot openstaande vacatures hoeft te leiden, maar ook aanpassingsprocessen op gang kan brengen. 
De prognoses voor de perspectieven en knelpunten naar beroepsgroep hebben alleen betrekking op de elementaire, lagere en middelbare beroepen, terwijl de prognoses voor de perspectieven en knelpunten naar opleidingstype alleen betrekking hebben op het Basisonderwijs, de VMBO-opleidingen en de opleidingen op MBO-niveau. Bij de hogere beroepen en opleidingen is de instroom op de arbeidsmarkt van afgestudeerden veel moeilijker aan één bepaalde regio of provincie toe te schrijven. Voor de hogere beroepen en opleidingen worden alleen prognoses voor de uitbreidings- en vervangingsvraag en de daaruit resulterende baanopeningen gepresenteerd.

In deel vijf is ook informatie opgenomen over de structurele positie van opleidingen op de arbeidsmarkt. Het betreft hier de conjunctuurgevoeligheid van de werkgelegenheid en de uitwijkmogelijkheden van de schoolverlaters op de arbeidsmarkt. Deze indicatoren hebben tot doel het perspectief in een breder kader te plaatsen. De prognoses van vraag en aanbod zijn uiteraard aan onzekerheid onderhevig. Bovendien zal een schoolverlater doorgaans een lange tijd op de arbeidsmarkt vertoeven. De structurele kenmerken beogen daarom een indicatie te geven van de risico's die men op een bepaald arbeidsmarktsegment loopt. Zo geeft de conjunctuurgevoeligheid aan in welke mate de werkgelegenheid voor het desbetreffende opleidingstype aan schommelingen onderhevig is, terwijl de uitwijkmogelijkheden aangeven in welke mate de werkenden afhankelijk zijn van de werkgelegenheidsontwikkelingen in één beroepsgroep of juist uit kunnen wijken naar meerdere beroepsgroepen.

In de meeste tabellen wordt ook een kwalitatieve typering gegeven van de gepresenteerde informatie. Dit maakt het mogelijk de informatie voor een bepaalde sector, beroepsgroep of opleiding snel te interpreteren. Bij de actuele arbeidsmarktinformatie wordt tevens een indicatie gegeven van de trend in de afgelopen jaren. Bij de informatie over beroepsgroepen, opleidingstypen en bedrijfssectoren gaat het hierbij om de ontwikkeling in de periode 1997-2001. De informatie over de trendmatige ontwikkeling heeft meestal betrekking op de ontwikkeling van het aandeel van de desbetreffende categorie. Alleen bij de tabellen 1.1, 1.9 en 1.16 gaat het om de ontwikkeling van het aantal werkenden.

Vermeldenswaardig is nog dat het ROA gedurende de laatste jaren de voorspelkwaliteit van de landelijke prognoses over de toekomstige vraag- en aanbodontwikkelingen naar beroep en opleiding heeft geëvalueerd na afloop van de prognoseperiode. Uit het laatste evaluatierapport ${ }^{2}$ blijkt onder meer dat voor de prognoseperiode 1993-1998 in 52\% van de ongeveer 100 opleidingstypen de juiste van de vijf mogelijke typeringen werd gegeven. Voor $83 \%$ van de opleidingstypen werd de juiste of de aangrenzende typering voorspeld.

Om de robuustheid van de informatie uit de EBB te vergroten, hebben de gepresenteerde gegevens telkens betrekking op het gemiddelde van de jaren 2000 en 2001. Om de herkenbaarheid van individuele respondenten te voorkomen, heeft het CBS de restrictie gesteld dat bij het publiceren van tweejaarlijkse gemiddelden alleen cijfers over categorieën mogen worden gepresenteerd die betrekking hebben op tenminste 2.500 personen, of op een randtotaal van tenminste 15.000 personen. In deel drie heeft het ROA, in het licht van de betrouwbaarheid van de informatie, de aantallen openstaande vacatures en niet-werkende werkzoekenden afgerond op tientallen. Bovendien is er een ondergrens van 10 gehanteerd. In de delen vier en vijf is een ondergrens van 2.000 personen gehanteerd. Wanneer er in een beroepsgroep of opleidingstype minder dan 2.000 mensen werkzaam zijn, worden alleen kwalitatieve typeringen van de verwachte ontwikkelingen gepresenteerd.

De informatie naar bedrijfssector is gebaseerd op de Standaard Bedrijfsindeling 1993 (SBI'93) van het CBS. De informatie naar beroepsgroep is gebaseerd op de Standaard Beroeps-

2. W. Smits en B. Diephuis, Evaluatie arbeidsmarktprognoses naar opleiding en beroep tot 1998, ROA-R2001/2, Maastricht. 
classificatie 1992 (SBC'92) van het CBS. Hierbij is de 3-digitcode van het CBS gebruikt, waarbij code 471 is uitgesplitst in Bakkers en slagers en Procesoperators. Bovendien is bij de elementaire beroepen een uitsplitsing gemaakt naar zes beroepsgroepen. Tevens is afgeweken van de door het CBS gehanteerde namen. In plaats daarvan worden kortere beroepsnamen gebruikt. Voor de informatie naar opleidingstype is door het ROA een eigen classificatie ontwikkeld waarin opleidingen geclusterd zijn die in hoge mate hetzelfde beroependomein kennen. Deze classificatie is overigens wel gekoppeld aan de Standaard Onderwijs Indeling (SOI) van het CBS. Achter in deze Statistische Bijlage is een overzicht opgenomen van de gehanteerde classificaties. Meer informatie over deze classificaties is opgenomen in de ROA-classificatiegids 2002. 
1 De werkgelegenheidstructuur in Overijssel 

Tabel 1.1

Aantal werkenden per bedrijfssector, Overijssel, gemiddelde 2000-2001

\begin{tabular}{|c|c|c|c|}
\hline Bedrijfssector & aantal & $\begin{array}{l}\text { Overijssel } \\
\text { t.o.v. } \\
\text { Nederland }\end{array}$ & $\begin{array}{l}\text { trend } \\
1997-2001\end{array}$ \\
\hline
\end{tabular}

\section{Landbouw en visserij}

Tuinbouw

Veehouderij

Akkerbouw, bosbouw en visserij

\section{Voeding}

Vlees- en visverwerking

Overige voedingsproducten

Drank en tabaksproducten

Chemie

Basischemie

Eindproducten chemie

Kunststofverwerking

Metaal en elektrotechniek

Basismetaal

Metaalproducten

Machine-industrie

Elektrotechniek

Transportmiddelen

Overige industrie

Textiel

Hout- en bouwmaterialen

Papier

Grafische industrie

Energie

Energie

Bouw en onroerend goed

Bouw

Exploitatie van onroerend goed

Handel en reparatie

Handel en reparatie

Transport en communicatie

Scheep- en luchtvaart

Weg- en railvervoer

Communicatie

\section{Bank- en verzekeringswezen}

Bankwezen

Verzekeringswezen
16.500

$\begin{array}{rll}- & \text { zeer laag } & \text { constant } \\ 13.500 & \text { hoog } & \text { dalend } \\ \text { - } & \text { gemiddeld } & \text { constant }\end{array}$

12.000

$5.000 \quad$ zeer hoog

6.000 gemiddeld

constant

constant

zeer laag sterk dalend

9.000

5.500

laag

gemiddeld

zeer hoog

sterk dalend

dalend

33.000

$\begin{array}{rll}- & \text { zeer laag } & - \\ 10.500 & \text { hoog } & \text { stijgend } \\ 9.500 & \text { hoog } & \text { dalend } \\ 8.000 & \text { gemiddeld } & \text { constant } \\ 4.000 & \text { gemiddeld } & \text { stijgend }\end{array}$

34.000

6.000 zeer hoog constant

460.000

18.000

-

hoog

hoog

stijgend

constant

4.500

4.500

hoog

constant

42.000

39.000

hoog constant

3.000

gemiddeld

stijgend

72.000

72.000 gemiddeld stijgend

20.500

$14.000^{-}$

zeer laag

gemiddeld

6.000

laag

constant

12.000

7.500

laag

laag

stijgend

4.500

constant 
Tabel 1.1 (vervolg)

Aantal werkenden per bedrijfssector, Overijssel, gemiddelde 2000-2001

\begin{tabular}{llll}
\hline Bedrijfsector & aantal & Overijssel & trend \\
& & t.o.v. \\
& Nederland & $1997-2001$ \\
& & \\
\hline
\end{tabular}

\section{Horeca en zakelijke dienstverlening}

\section{Horeca}

Zakelijke dienstverlening

Overige commerciële dienstverlening

\section{Kwartaire diensten}

Gezondheidszorg

Overige kwartaire diensten

Overheid en onderwijs

Onderwijs

Overheid

Totaal
59.000

12.000 gemiddeld sterk stijgend

37.500 laag stijgend

9.500 gemiddeld constant

72.500

65.500 gemiddeld stijgend

65.000

34.500 gemiddeld stijgend

30.000 gemiddeld constant

$460.000 \quad$ - $\quad$ stijgend

Bron: CBS/ROA 
Tabel 1.2

Belangrijkste opleidingsniveaus van de werkenden per bedrijfssector, Overijssel, gemiddelde 2000-2001

$\begin{array}{lll}\text { Bedrijfssector } & \% & \text { trend } 1997-2001\end{array}$

\section{Landbouw en visserij}

Basisonderwijs

VMBO

HAVO/VWO/MBO

$\mathrm{HBO}$

WO

Voeding

Basisonderwijs

VMBO

HAVO/NWO/MBO

$\mathrm{HBO}$

WO

\section{Chemie}

Basisonderwijs

VMBO

HAVO/NWO/MBO

HBO

WO

Metaal en elektrotechniek

Basisonderwijs

VMBO

HAVO/VWO/MBO

HBO

WO

sterk dalend
constant

-

stijgend

constant

constant

-

stijgend

stijgend

constant

stijgend

\section{Overige industrie}

Basisonderwijs

VMBO

HAVO/NWO/MBO

$\mathrm{HBO}$

WO

$\begin{aligned} 28 & \text { stijgend } \\ 48 & \text { constant } \\ 12 & - \\ 4 & \text { stijgend }\end{aligned}$

\section{Energie}

Basisonderwijs

VMBO

HAVO/NWO/MBO

$\mathrm{HBO}$

WO

Bouw en onroerend goed

Basisonderwijs

VMBO

HAVO/NWO/MBO

$\mathrm{HBO}$

$\begin{aligned} 22 & \text { stijgend } \\ 27 & \text { dalend } \\ 40 & \text { constant } \\ 9 & \text { stijgend }\end{aligned}$

WO 
Tabel 1.2 (vervolg)

Belangrijkste opleidingsniveaus van de werkenden per bedrijfssector, Overijssel, gemiddelde 2000-2001

Bedrijfssector $\quad \% \quad$ trend 1997-2001

Handel en reparatie

Basisonderwijs

VMBO

HAVO/MWO/MBO

HBO

WO

constant

stijgend

constant

constant

Transport en communicatie

Basisonderwijs

VMBO

HAVO/NWO/MBO

$\mathrm{HBO}$

WO

Bank- en verzekeringswezen

Basisonderwijs

VMBO

HAVO/NWO/MBO

$\mathrm{HBO}$

WO

\section{Horeca en zakelijke dienstverlening}

Basisonderwijs

VMBO

HAVO/VWO/MBO

HBO

WO

dalend

$47 \quad$ constant

\section{Kwartaire diensten}

Basisonderwijs

VMBO

HAVO/NWO/MBO

HBO

WO

Overheid en onderwijs

Basisonderwijs

VMBO

HAVO/VWO/MBO

HBO

WO

Totaal

Basisonderwijs

VMBO

HAVO/VWO/MBO

$\mathrm{HBO}$

WO

constant

constant constant constant

Bron: CBS/ROA

constant constant constant constant constant

constant constant constant constant constant 
Tabel 1.3

Percentage jongeren (15-29 jaar) per bedrijfssector, Overijssel, gemiddelde 2000-2001

\begin{tabular}{|c|c|c|c|c|}
\hline Bedrijfssector & $\%$ & typering & $\begin{array}{l}\text { Overijssel } \\
\text { t.o.v. } \\
\text { Nederland }\end{array}$ & $\begin{array}{l}\text { trend } \\
1997-2001\end{array}$ \\
\hline Landbouw en visserij & 18 & laag & zeer laag & dalend \\
\hline Voeding & 35 & hoog & zeer hoog & constant \\
\hline Chemie & - & gemiddeld & - & - \\
\hline Metaal en elektrotechniek & 23 & gemiddeld & laag & dalend \\
\hline Overige industrie & 18 & laag & laag & - \\
\hline Energie & - & zeer laag & - & - \\
\hline Bouw en onroerend goed & 31 & gemiddeld & gemiddeld & constant \\
\hline Handel en reparatie & 40 & zeer hoog & gemiddeld & constant \\
\hline Transport en communicatie & 29 & gemiddeld & hoog & stijgend \\
\hline Bank- en verzekeringswezen & 31 & gemiddeld & hoog & - \\
\hline Horeca en zakelijke dienstverlening & 34 & hoog & gemiddeld & dalend \\
\hline Kwartaire diensten & 24 & gemiddeld & gemiddeld & dalend \\
\hline Overheid en onderwijs & 20 & laag & gemiddeld & constant \\
\hline Totaal & 28 & _ & _ & constant \\
\hline
\end{tabular}

Bron: CBS/ROA 
Tabel 1.4

Percentage ouderen (50-64 jaar) per bedrijfssector, Overijssel, gemiddelde 2000-2001

\begin{tabular}{|c|c|c|c|c|}
\hline Bedrijfssector & $\%$ & typering & $\begin{array}{l}\text { Overijssel } \\
\text { t.o.v. } \\
\text { Nederland }\end{array}$ & $\begin{array}{l}\text { trend } \\
1997-2001\end{array}$ \\
\hline Landbouw en visserij & 29 & hoog & zeer hoog & - \\
\hline Voeding & - & zeer laag & - & _ \\
\hline Chemie & - & gemiddeld & - & - \\
\hline Metaal en elektrotechniek & 18 & gemiddeld & gemiddeld & stijgend \\
\hline Overige industrie & 21 & hoog & gemiddeld & constant \\
\hline Energie & - & zeer hoog & - & - \\
\hline Bouw en onroerend goed & 17 & gemiddeld & laag & constant \\
\hline Handel en reparatie & 15 & laag & gemiddeld & stijgend \\
\hline Transport en communicatie & 19 & gemiddeld & hoog & constant \\
\hline Bank- en verzekeringswezen & - & gemiddeld & - & - \\
\hline Horeca en zakelijke dienstverlening & 16 & laag & hoog & stijgend \\
\hline Kwartaire diensten & 17 & gemiddeld & zeer laag & sterk stijgend \\
\hline Overheid en onderwijs & 23 & hoog & laag & constant \\
\hline Totaal & 18 & _- & - & constant \\
\hline
\end{tabular}

Bron: CBS/ROA 
Tabel 1.5

Percentage vrouwen per bedrijfssector, Overijssel, gemiddelde 2000-2001

\begin{tabular}{|c|c|c|c|c|}
\hline Bedrijfssector & $\%$ & typering & $\begin{array}{l}\text { Overijssel } \\
\text { t.o.v. } \\
\text { Nederland }\end{array}$ & $\begin{array}{l}\text { trend } \\
1997-2001\end{array}$ \\
\hline Landbouw en visserij & 25 & gemiddeld & gemiddeld & stijgend \\
\hline Voeding & 24 & gemiddeld & laag & constant \\
\hline Chemie & - & laag & - & - \\
\hline Metaal en elektrotechniek & 12 & laag & laag & stijgend \\
\hline Overige industrie & 21 & laag & zeer laag & constant \\
\hline Energie & - & gemiddeld & - & - \\
\hline Bouw en onroerend goed & 9 & zeer laag & laag & constant \\
\hline Handel en reparatie & 41 & gemiddeld & gemiddeld & constant \\
\hline Transport en communicatie & 28 & gemiddeld & zeer hoog & stijgend \\
\hline Bank- en verzekeringswezen & 49 & hoog & hoog & constant \\
\hline Horeca en zakelijke dienstverlening & 41 & gemiddeld & gemiddeld & constant \\
\hline Kwartaire diensten & 74 & zeer hoog & gemiddeld & constant \\
\hline Overheid en onderwijs & 45 & hoog & hoog & stijgend \\
\hline Totaal & 38 & - & - & constant \\
\hline
\end{tabular}

Bron: CBS/ROA 
Tabel 1.6

Percentage flexibel werk per bedrijfssector, Overijssel, gemiddelde 2000-2001

\begin{tabular}{|c|c|c|c|c|}
\hline Bedrijfssector & $\%$ & typering & $\begin{array}{l}\text { Overijssel } \\
\text { t.o.v. } \\
\text { Nederland }\end{array}$ & $\begin{array}{l}\text { trend } \\
1997-2001\end{array}$ \\
\hline Landbouw en visserij & - & zeer laag & - & - \\
\hline Voeding & - & hoog & - & _ \\
\hline Chemie & - & gemiddeld & - & - \\
\hline Metaal en elektrotechniek & 8 & gemiddeld & gemiddeld & constant \\
\hline Overige industrie & 6 & gemiddeld & laag & dalend \\
\hline Energie & - & gemiddeld & - & - \\
\hline Bouw en onroerend goed & 3 & laag & zeer laag & sterk dalend \\
\hline Handel en reparatie & 11 & gemiddeld & gemiddeld & dalend \\
\hline Transport en communicatie & 13 & hoog & hoog & constant \\
\hline Bank- en verzekeringswezen & - & laag & - & - \\
\hline Horeca en zakelijke dienstverlening & 13 & hoog & gemiddeld & dalend \\
\hline Kwartaire diensten & 9 & gemiddeld & gemiddeld & dalend \\
\hline Overheid en onderwijs & 6 & laag & zeer hoog & dalend \\
\hline Totaal & 9 & - & _ & dalend \\
\hline
\end{tabular}

Bron: CBS/ROA 
Tabel 1.7

Percentage deeltijdwerk per bedrijfssector, Overijssel, gemiddelde 2000-2001

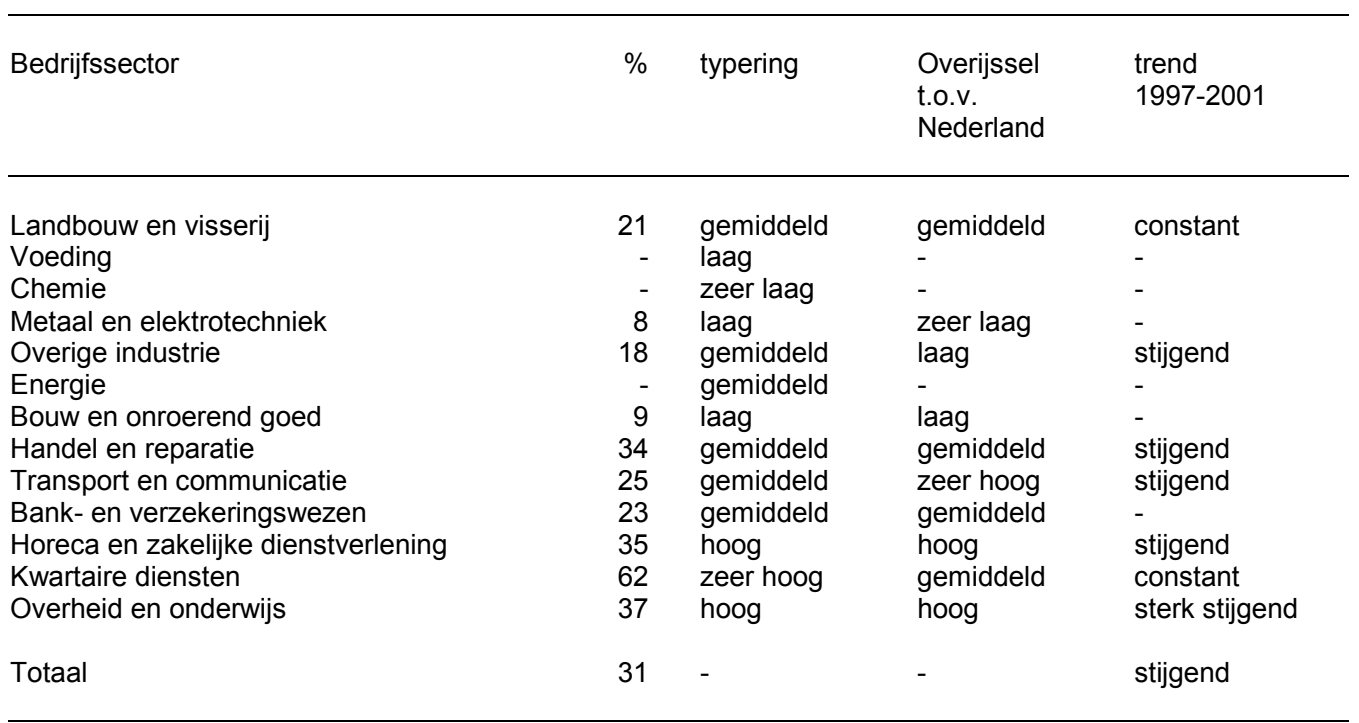

Bron: CBS/ROA 
Tabel 1.8

Percentage zelfstandigen per bedrijfssector, Overijssel, gemiddelde 2000-2001

\begin{tabular}{|c|c|c|c|c|}
\hline Bedrijfssector & $\%$ & typering & $\begin{array}{l}\text { Overijssel } \\
\text { t.o.v. } \\
\text { Nederland }\end{array}$ & $\begin{array}{l}\text { trend } \\
1997-2001\end{array}$ \\
\hline Landbouw en visserij & 75 & zeer hoog & zeer hoog & constant \\
\hline Voeding & - & gemiddeld & - & - \\
\hline Chemie & - & - & - & - \\
\hline Metaal en elektrotechniek & 3 & - & laag & sterk stijgend \\
\hline Overige industrie & 6 & gemiddeld & gemiddeld & - \\
\hline Energie & - & zeer laag & - & - \\
\hline Bouw en onroerend goed & 12 & gemiddeld & gemiddeld & stijgend \\
\hline Handel en reparatie & 16 & hoog & hoog & dalend \\
\hline Transport en communicatie & 4 & gemiddeld & gemiddeld & dalend \\
\hline Bank- en verzekeringswezen & - & gemiddeld & - & - \\
\hline Horeca en zakelijke dienstverlening & 19 & hoog & hoog & constant \\
\hline Kwartaire diensten & 6 & gemiddeld & laag & - \\
\hline Overheid en onderwijs & 1 & - & zeer laag & - \\
\hline Totaal & 11 & - & - & constant \\
\hline
\end{tabular}

Bron: CBS/ROA 
Tabel 1.9

Aantal werkenden per beroepssegment, Overijssel, gemiddelde 2000-2001

\begin{tabular}{|c|c|c|c|}
\hline Beroepssegment & aantal & $\begin{array}{l}\text { Overijssel } \\
\text { t.o.v. } \\
\text { Nederland }\end{array}$ & $\begin{array}{l}\text { trend } \\
1997-2001\end{array}$ \\
\hline
\end{tabular}

\section{Elementaire beroepen}

Kantoorhulpen, inpakkers en colporteurs

Agrarische hulparbeiders

Productiemedewerkers

Laders en lossers

Vakkenvullers

Interieurverzorgers

\section{Lagere niet-specialistische beroepen}

Ondersteunende administratieve hulpkrachten

\section{Lagere docenten sportvakken}

Zweminstructeurs

\section{Lagere agrarische beroepen}

Agrarische arbeiders

Landbouwmachinebestuurders en vissers

Lagere wiskundige, natuurwetenschappelijke beroepen

Laboratorium-assistenten

Lagere technische beroepen

Conciërges

Bouwvakkers

Weg- en waterbouwkundige arbeiders

Metaalarbeiders

Assembleurs

Monteurs en controleurs elektrotechnische producten

Grafisch productiepersoneel

Mechanisch operators

Confectie-arbeiders

\section{Lagere transportberoepen}

Chauffeurs

\section{Lagere (para)medische beroepen}

Verpleeghulpen en leerling-verpleegkundigen

Lagere administratieve, commerciële beroepen e.d.

Receptionisten en administratieve employés

Verzekeringsagenten

Verkopers

\section{Lagere beveiligingsberoepen}

Aspirant politieagenten, soldaten en beveiligingshulpkrachten

\subsection{0}

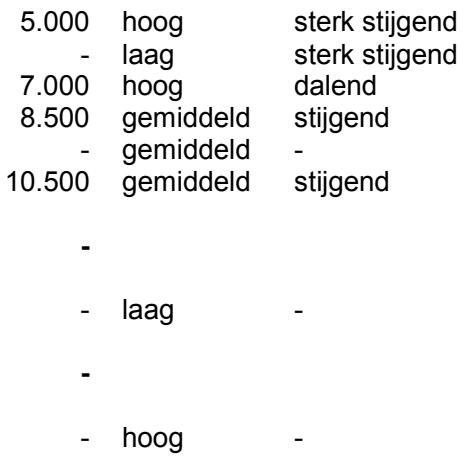

7.500

7.000 gemiddeld - gemiddeld

dalend sterk dalend

- laag

44.500

$\begin{array}{rll}17.000 & \text { gemiddeld } & \text { dalend } \\ - & \text { hoog } & \text { constant } \\ 7.500 & \text { hoog } & \text { constant } \\ \text { - } & \text { hoog } & \text { constant } \\ \text { - } & \text { zeer hoog } & \text { sterk stijgend } \\ - & \text { hoog } & - \\ 6.500 & \text { zeer hoog } & \text { dalend } \\ 3.500 & \text { zeer hoog } & \text { constant } \\ & & \\ 15.000 & & \\ 15.000 & \text { gemiddeld } & \text { constant } \\ & & \\ - & & \\ - & \text { gemiddeld } & \text { sterk stijgend } \\ 34.500 & & \\ 13.500 & \text { gemiddeld } & \text { constant } \\ - & \text { gemiddeld } & \text { sterk stijgend } \\ 19.500 & \text { gemiddeld } & \text { stijgend } \\ 3.500 & & \\ 3.500 & \text { gemiddeld } & \text { sterk stijgend }\end{array}$


Tabel 1.9 (vervolg)

Aantal werkenden per beroepssegment, Overijssel, gemiddelde 2000-2001

$\begin{array}{ccc}\text { Beroepssegment } & \text { aantal } & \text { Overijssel trend } \\ & \text { t.o.v. } & 1997-2001 \\ & \text { Nederland }\end{array}$

Lagere verzorgende beroepen

Hulpkrachten horeca en verzorging

Café- en snackbarhouders

\section{Middelbare docenten transport- en sportvakken}

Rij-instructeurs

Sportinstructeurs

\section{Middelbare agrarische beroepen}

Agrarische vakkrachten

Agrarische bedrijfshoofden

Middelbare wiskundige, natuurwetenschappelijke beroepen

Laboranten

\section{Middelbare technische beroepen}

Hoofden technische dienst

Weg- en waterbouwkundige vakkrachten

Bankwerkers en lassers

Monteurs

Elektronicamonteurs

Elektromonteurs

Grafische vakkrachten

Schoen- en kleermakers

Brandweerlieden

Procesoperators

Bakkers en slagers

\section{Middelbare transportberoepen e.d.}

Schippers en conducteurs

Administratieve transportemployés

Stewards

\section{Middelbare (para)medische beroepen}

Verplegenden en doktersassistenten

Apothekersassistenten en medisch laboranten

Medisch secretaresses

Ziekenverzorgenden

Middelbare administratieve, commerciële beroepen e.d.

Productieplanners

Programmeurs

Boekhouders en secretaresses

Commercieel employés

Winkeliers

Technisch-commercieel employés

\subsection{0}

9.500 gemiddeld constant

- zeer hoog sterk stijgend

- zeer laag

- gemiddeld constant

12.500

gemiddeld -

12.000 zeer hoog constant

- zeer laag -

58.000

- gemiddeld -

3.500 zeer hoog sterk stijgend

5.500 hoog constant

15.000 gemiddeld constant

- gemiddeld constant

7.000 hoog

3.000 hoog

- hoog

- gemiddeld

3.500 gemiddeld -

- gemiddeld -

- zeer laag -

- laag

- zeer laag

18.500

7.000 gemiddeld constant

- laag constant

- hoog constant

7.500 zeer hoog sterk stijgend

65.000

3.500 gemiddeld -

5.000 gemiddeld sterk stijgend

26.000 gemiddeld constant

17.000 gemiddeld constant

11.000 hoog stijgend

zeer hoog stijgend 
Tabel 1.9 (vervolg)

Aantal werkenden per beroepssegment, Overijssel, gemiddelde 2000-2001

$\begin{array}{ccc}\text { Beroepssegment } & \text { aantal } & \text { Overijssel trend } \\ & \text { t.o.v. } & 1997-2001 \\ & \text { Nederland }\end{array}$

Middelbare juridische, bestuurlijke beveiligingsberoepen

Juridisch en fiscaal medewerkers

Politieagenten, onderofficieren en beveiligingsemployés

\section{Middelbare taalkundige, culturele beroepen}

Bibliotheekassistenten

Grafisch ontwerpers

\section{Middelbare beroepen m.b.t. gedrag en maatschappij}

Activiteitenbegeleiders en medewerkers arbeidsbemiddeling

Middelbare verzorgende beroepen e.d.

Verzorgend personeel

Bedrijfshoofden horeca

\section{Hogere pedagogische beroepen}

Docenten $2 \mathrm{e}$ graads zonder specialisatie

Onderwijskundig medewerkers

Leraar basisonderwijs

Docenten exacte, medische en verzorgende vakken (2e graads)

Docenten landbouw en techniek (2e graads)

Docenten economisch-administratieve vakken (2e graads)

Docenten talen en expressie

Docenten sociale vakken (2e graads)

\section{Hogere landbouwkundige beroepen}

Milieuhygiënisten en agrarisch vertegenwoordigers

Hogere wiskundige, natuurwetenschappelijke beroepen

Technisch analisten

Hogere technische beroepen

Architecten en bouwkundig projectleiders

Weg- en waterbouwkundig ontwerpers en projectleiders

Bedrijfshoofden metaalbewerking

Werktuigbouwkundig ontwerpers en hoofden technische dienst

Technisch systeemanalisten

Elektrotechnisch ontwerpers en bedrijfshoofden

Procestechnologen

\section{Hogere transportberoepen}

Vliegers, scheepskapiteins en leidinggevenden transport

\section{Hogere (para)medische beroepen}

Therapeuten en verpleegkundigen

Medisch analisten

\subsection{0}

3.000 hoog stijgend

3.000 gemiddeld -

gemiddeld sterk dalend

hoog

6.000

6.000 hoog sterk stijgend

16.500

13.500 gemiddeld constant

2.500 gemiddeld -

22.000

- gemiddeld sterk dalend

- gemiddeld constant

13.000 zeer hoog stijgend

- hoog constant

- hoog -

- zeer hoog sterk stijgend

2.500 gemiddeld stijgend

- zeer hoog sterk stijgend

gemiddeld dalend

- laag sterk stijgend

6.500

- laag

- gemiddeld sterk stijgend

- hoog sterk stijgend

- gemiddeld -

- zeer laag -

- gemiddeld -

- hoog stijgend

- zeer laag -

8.000

7.000 gemiddeld constant

- gemiddeld sterk stijgend 
Tabel 1.9 (vervolg)

Aantal werkenden per beroepssegment, Overijssel, gemiddelde 2000-2001

$\begin{array}{ccc}\text { Beroepssegment } & \text { aantal } & \text { Overijssel trend } \\ & \text { t.o.v. } & 1997-2001 \\ & \text { Nederland }\end{array}$

Hogere administratieve, commerciële beroepen

Bedrijfshoofden

Organisatie-adviseurs

Systeemanalisten

Assistent accountants

Commercieel medewerkers

Technisch-bedrijfskundig medewerkers

Hogere juridische, bestuurlijke, beveiligingsberoepen

Juridisch, bestuurlijk medewerkers

Politie-inspecteurs en officieren

Hogere taalkundige, culturele beroepen

Tolken, vertalers en schrijvers

Bibliothecarissen

Kunstenaars

\section{Hogere beroepen m.b.t. gedrag en maatschappij e.d.}

Geestelijk verzorgers

Medewerkers sociaal-cultureel werk en personeel en arbeid

Journalisten

Sociaal-wetenschappelijk medewerkers

\section{Hogere verzorgende beroepen}

Afdelingshoofden zorginstelling

Managers (HBO werk- en denkniveau)

Leidinggevenden

\section{Wetenschappelijke pedagogische beroepen}

Docent 1e graads zonder specialisatie

Onderwijskundigen en pedagogen

Docenten exacte, medische en verzorgende vakken (1e graads)

Docenten landbouw en techniek (1e graads)

Docenten economisch-administratieve vakken (1e graads)

Docenten letteren (1e graads)

Docenten sociale vakken (1e graads)

\section{Wetenschappelijke landbouwkundige beroepen}

Landbouwkundigen

Wetensch. wiskundige, natuurwetenschappelijke beroepen

Natuurwetenschappers

Wetenschappelijke technische beroepen

Werktuigbouwkundigen

Weg- en waterbouwkundigen

\subsection{0}

$$
\begin{array}{rll}
2.500 & \text { laag } & \text { sterk stijgend } \\
\text { - } & \text { laag } & \text { - } \\
6.500 & \text { gemiddeld } & \text { stijgend } \\
4.500 & \text { gemiddeld } & \text { sterk dalend } \\
13.000 & \text { gemiddeld } & \text { stijgend } \\
\text { - } & \text { laag } & \text { - } \\
\text { - } & & \\
\text { - } & \text { laag } & \text { - } \\
\text { - } & \text { zeer laag } & \text { constant }
\end{array}
$$

3.000

- laag sterk stijgend

- gemiddeld sterk stijgend

- laag stijgend

8.500

- zeer hoog sterk stijgend

6.500 gemiddeld constant

- gemiddeld -

- gemiddeld sterk stijgend

- laag

2.500

2.500 laag

4.500

hoog

gemiddeld -

- zeer laag sterk dalend

- zeer hoog -

- laag

- gemiddeld dalend

- laag

zeer laag -

- laag

2.500

- gemiddeld sterk stijgend

- laag 
Tabel 1.9 (vervolg)

Aantal werkenden per beroepssegment, Overijssel, gemiddelde 2000-2001

$\begin{array}{cc}\text { Beroepssegment } & \text { aantal Overijssel trend } \\ & \text { t.o.v. 1997-2001 } \\ & \text { Nederland }\end{array}$

\section{Wetenschappelijke technische beroepen (vervolg)}

Elektrotechnici

Materiaalkundigen

\section{Wetenschappelijke (para)medische beroepen}

\section{Artsen}

Apothekers

Wetenschappelijke economische, administratieve beroepen

\section{Economen}

Organisatiedeskundigen

Informatici

Accountants

Wetenschappelijke juridische, bestuurlijke beroepen

Juristen

Wetenschappelijke beroepen m.b.t. gedrag en maatschappij

Geestelijken

Hoofden sociaal-cultureel werk en personeel en arbeid

Taalkundigen

Sociaal-wetenschappelijk onderzoekers

Managers (wetenschappelijk werk- en denkniveau)

Managers

Totaal

Bron: CBS/ROA
- zeer laag -

- hoog constant

3.000

3.000 laag constant - gemiddeld -

4.500

laag

- zeer laag -

- zeer laag sterk stijgend

- laag stijgend

3.000

3.000 laag constant

- laag -

- hoog constant

- laag -

6.500

6.500 gemiddeld sterk stijgend

460.000

stijgend 
Tabel 1.10

Percentage jongeren (15-29 jaar) per beroepssegment, Overijssel, gemiddelde 2000-2001

\begin{tabular}{|c|c|c|c|c|}
\hline Beroepssegment & $\%$ & typering & $\begin{array}{l}\text { Overijssel } \\
\text { t.o.v. } \\
\text { Nederland }\end{array}$ & $\begin{array}{l}\text { trend } \\
1997-2001\end{array}$ \\
\hline Elementaire beroepen & 40 & hoog & hoog & constant \\
\hline Lagere niet-specialistische beroepen & - & laag & - & - \\
\hline Lagere docenten sportvakken & - & zeer hoog & _ & _ \\
\hline Lagere agrarische beroepen & 34 & hoog & laag & constant \\
\hline Lagere wiskundige, natuurwetenschappelijke beroepen & - & gemiddeld & - & - \\
\hline Lagere technische beroepen & 26 & gemiddeld & zeer laag & dalend \\
\hline Lagere transportberoepen & 28 & gemiddeld & zeer hoog & constant \\
\hline Lagere (para)medische beroepen & - & zeer hoog & - & - \\
\hline Lagere administratieve, commerciële beroepen e.d. & 43 & zeer hoog & gemiddeld & constant \\
\hline Lagere beveiligingsberoepen & - & hoog & - & - \\
\hline Lagere verzorgende beroepen & 32 & hoog & laag & constant \\
\hline Middelbare docenten transport- sportvakken & - & laaq & _ & _ \\
\hline Middelbare agrarische beroepen & - & laag & - & - \\
\hline Middelbare wiskundige, natuurwetenschappelijke beroepen & - & zeer hoog & _ & _ \\
\hline Middelbare technische beroepen & 26 & gemiddeld & laag & constant \\
\hline Middelbare transportberoepen e.d. & - & laag & - & - \\
\hline Middelbare (para)medische beroepen & 27 & gemiddeld & gemiddeld & constant \\
\hline $\begin{array}{l}\text { Middelbare administratieve, commerciële beroepen e.d. } \\
\text { Middelbare juridische, bestuurlijke beveiligingsberoepen }\end{array}$ & 29 & $\begin{array}{l}\text { gemiddeld } \\
\text { gemiddeld }\end{array}$ & gemiddeld & dalend \\
\hline Middelbare taalkundige, culturele beroepen & - & hoog & - & - \\
\hline Middelbare beroepen mbt. gedrag en maatschappii & - & hoog & _ & _ \\
\hline Middelbare verzorgende beroepen e.d. & 33 & hoog & gemiddeld & dalend \\
\hline Hogere pedagogische beroepen & 19 & gemiddeld & hoog & - \\
\hline Hogere landbouwkundige beroepen & - & gemiddeld & - & - \\
\hline Hogere wiskundige, natuurwetenschappelijke beroepen & - & hoog & - & _ \\
\hline Hogere technische beroepen & - & gemiddeld & - & - \\
\hline Hogere transportberoepen & - & gemiddeld & - & - \\
\hline Hogere (para)medische beroepen & - & gemiddeld & - & - \\
\hline Hogere administratieve, commerciële beroepen & 23 & gemiddeld & hoog & dalend \\
\hline Hogere juridische, bestuurlijke, beveiligingsberoepen & - & laag & - & - \\
\hline Hogere taalkundige, culturele beroepen & - & zeer laag & - & - \\
\hline Hogere beroepen mbt. gedrag en maatschappij e.d. & - & gemiddeld & - & - \\
\hline Hogere verzorgende beroepen & - & zeer laag & - & - \\
\hline Managers (HBO werk- en denkniveau) & - & laag & - & - \\
\hline Wetenschappelijke pedagogische beroepen & - & gemiddeld & - & - \\
\hline Wetenschappelijke landbouwkundige beroepen & - & zeer laag & - & - \\
\hline Wetensch. wiskundige, natuurwetenschappelijke beroepen & - & zeer laag & - & - \\
\hline Wetenschappelijke technische beroepen & - & gemiddeld & - & - \\
\hline Wetenschappelijke (para)medische beroepen & - & hoog & - & - \\
\hline Wetenschappelijke economische, administratieve beroepen & - & laag & - & - \\
\hline Wetenschappelijke juridische, bestuurlijke beroepen & - & hoog & _ & - \\
\hline Wetenschappelijke beroepen mbt. gedrag en maatschappij & - & laag & - & - \\
\hline Managers (wetenschappelijk werk- en denkniveau) & - & laag & - & - \\
\hline Totaal & 28 & - & - & constant \\
\hline
\end{tabular}

Bron: CBS/ROA 
Tabel 1.11

Percentage ouderen (50-64 jaar) per beroepssegment, Overijssel, gemiddelde 2000-2001

\begin{tabular}{|c|c|c|c|c|}
\hline Beroepssegment & $\%$ & typering & $\begin{array}{l}\text { Overijssel } \\
\text { t.o.v. } \\
\text { Nederland }\end{array}$ & $\begin{array}{l}\text { trend } \\
1997-2001\end{array}$ \\
\hline Elementaire beroepen & 16 & gemiddeld & laag & constant \\
\hline Lagere niet-specialistische beroepen & - & gemiddeld & - & - \\
\hline Lagere docenten sportvakken & - & zeer laag & - & - \\
\hline Lagere agrarische beroepen & - & gemiddeld & - & - \\
\hline Lagere wiskundige, natuurwetenschappelijke beroepen & - & zeer hoog & - & - \\
\hline Lagere technische beroepen & 19 & gemiddeld & gemiddeld & stijgend \\
\hline Lagere transportberoepen & 23 & hoog & gemiddeld & sterk stijgend \\
\hline Lagere (para)medische beroepen & - & laag & - & - \\
\hline Lagere administratieve, commerciële beroepen e.d. & 11 & laag & zeer laag & constant \\
\hline Lagere beveiligingsberoepen & - & laag & - & - \\
\hline Lagere verzorgende beroepen & - & hoog & - & - \\
\hline Middelbare docenten transport-, sportvakken & - & gemiddeld & - & - \\
\hline Middelbare agrarische beroepen & 37 & zeer hoog & hoog & constant \\
\hline Middelbare wiskundige, natuurwetenschappelijke beroepen & - & zeer laag & - & - \\
\hline Middelbare technische beroepen & 20 & gemiddeld & gemiddeld & constant \\
\hline Middelbare transportberoepen e.d. & - & zeer hoog & - & - \\
\hline Middelbare (para)medische beroepen & 12 & laag & gemiddeld & constant \\
\hline Middelbare administratieve, commerciële beroepen e.d. & 15 & gemiddeld & gemiddeld & constant \\
\hline Middelbare juridische, bestuurlijke beveiligingsberoepen & - & laag & - & - \\
\hline Middelbare taalkundige, culturele beroepen & - & gemiddeld & - & - \\
\hline Middelbare beroepen mbt. gedrag en maatschappij & - & gemiddeld & - & - \\
\hline Middelbare verzorgende beroepen e.d. & 17 & gemiddeld & hoog & - \\
\hline Hogere pedagogische beroepen & 20 & gemiddeld & laag & - \\
\hline Hogere landbouwkundige beroepen & 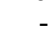 & zeer laag & - & - \\
\hline Hogere wiskundige, natuurwetenschappelijke beroepen & - & laag & - & - \\
\hline Hogere technische beroepen & - & laag & - & - \\
\hline Hogere transportberoepen & _ & zeer laag & - & - \\
\hline Hogere (para)medische beroepen & - & gemiddeld & - & - \\
\hline Hogere administratieve, commerciële beroepen & 21 & gemiddeld & zeer hoog & stijgend \\
\hline Hogere juridische, bestuurlijke, beveiligingsberoepen & - & laag & - & - \\
\hline Hogere taalkundige, culturele beroepen & - & hoog & - & - \\
\hline Hogere beroepen mbt. gedrag en maatschappij e.d. & - & hoog & - & - \\
\hline Hogere verzorgende beroepen & - & hoog & - & - \\
\hline Managers (HBO werk- en denkniveau) & - & hoog & - & - \\
\hline Wetenschappelijke pedagogische beroepen & - & zeer hoog & - & - \\
\hline Wetenschappelijke landbouwkundige beroepen & - & gemiddeld & - & - \\
\hline Wetensch. wiskundige, natuurwetenschappelijke beroepen & - & gemiddeld & - & - \\
\hline Wetenschappelijke technische beroepen & _ & gemiddeld & - & - \\
\hline Wetenschappelijke (para)medische beroepen & - & gemiddeld & - & - \\
\hline Wetenschappelijke economische, administratieve beroepen & - & laag & - & - \\
\hline Wetenschappelijke juridische, bestuurlijke beroepen & - & hoog & - & - \\
\hline Wetenschappelijke beroepen mbt. gedrag en maatschappij & 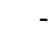 & hoog & - & - \\
\hline Managers (wetenschappelijk werk- en denkniveau) & 16 & gemiddeld & laag & constant \\
\hline Totaal & 18 & - & - & constant \\
\hline
\end{tabular}

Bron: CBS/ROA 
Tabel 1.12

Percentage vrouwen per beroepssegment, Overijssel, gemiddelde 2000-2001

\begin{tabular}{llll}
\hline Beroepssegment & $\%$ typering & $\begin{array}{l}\text { Overijssel trend } \\
\text { t.o.v. }\end{array}$ & 1997-2001 \\
& & Nederland & \\
& &
\end{tabular}

Elementaire beroepen

Lagere niet-specialistische beroepen

Lagere docenten sportvakken

Lagere agrarische beroepen

Lagere wiskundige, natuurwetenschappelijke beroepen

Lagere technische beroepen

Lagere transportberoepen

Lagere (para)medische beroepen

Lagere administratieve, commerciële beroepen e.d.

Lagere beveiligingsberoepen

Lagere verzorgende beroepen

Middelbare docenten transport-, sportvakken

Middelbare agrarische beroepen

Middelbare wiskundige, natuurwetenschappelijke beroepen

Middelbare technische beroepen

Middelbare transportberoepen e.d.

Middelbare (para)medische beroepen

Middelbare administratieve, commerciële beroepen e.d.

Middelbare juridische, bestuurlijke beveiligingsberoepen

Middelbare taalkundige, culturele beroepen

Middelbare beroepen mbt. gedrag en maatschappij

Middelbare verzorgende beroepen e.d.

Hogere pedagogische beroepen

Hogere landbouwkundige beroepen

Hogere wiskundige, natuurwetenschappelijke beroepen

Hogere technische beroepen

Hogere transportberoepen

Hogere administratieve, commerciële beroepen

Hogere juridische, bestuurlijke, beveiligingsberoepen

Hogere taalkundige, culturele beroepen

Hogere beroepen mbt. gedrag en maatschappij e.d.

Hogere verzorgende beroepen

Managers (HBO werk- en denkniveau)

Wetenschappelijke pedagogische beroepen

Wetenschappelijke landbouwkundige beroepen

Wetensch. wiskundige, natuurwetenschappelijke beroepen

Wetenschappelijke technische beroepen

Wetenschappelijke (para)medische beroepen

Wetenschappelijke juridische, bestuurlijke beroepen

Wetenschappelijke beroepen mbt. gedrag en maatschappij

Managers (wetenschappelijk werk- en denkniveau)

Totaal
Hogere (para)medische beroepen

Wetenschappelijke economische, administratieve beroepen

\begin{tabular}{|c|c|c|c|}
\hline 45 & hoog & gemiddeld & constant \\
\hline- & gemiddeld & - & - \\
\hline 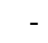 & zeer hoog & - & - \\
\hline - & laag & - & - \\
\hline 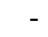 & zeer laag & - & - \\
\hline 12 & laag & zeer hoog & constant \\
\hline - & laag & - & - \\
\hline - & zeer hoog & - & - \\
\hline 75 & hoog & hoog & constant \\
\hline - & laag & & - \\
\hline 74 & hoog & laag & dalend \\
\hline- & gemiddeld & - & - \\
\hline 28 & $\begin{array}{l}\text { gemiddeld } \\
\text { gemiddeld }\end{array}$ & $\begin{array}{l}\text { hoog } \\
\text { - }\end{array}$ & sterk stijgend \\
\hline 5 & zeer laag & laag & stijgend \\
\hline - & gemiddeld & - & - \\
\hline 87 & zeer hoog & gemiddeld & constant \\
\hline 48 & hoog & zeer laag & constant \\
\hline & gemiddeld & - & - \\
\hline - & hoog & - & - \\
\hline 66 & hoog & laag & dalend \\
\hline 71 & hoog & gemiddeld & constant \\
\hline 64 & hoog & gemiddeld & stijgend \\
\hline 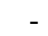 & laag & - & - \\
\hline- & laag & - & - \\
\hline - & laag & - & - \\
\hline - & zeer laag & - & - \\
\hline 79 & hoog & laag & constant \\
\hline 30 & $\begin{array}{l}\text { gemiddeld } \\
\text { gemiddeld }\end{array}$ & hoog & stijgend \\
\hline - & gemiddeld & - & - \\
\hline 56 & hoog & laag & constant \\
\hline - & zeer hoog & - & - \\
\hline - & laag & - & - \\
\hline - & gemiddeld & - & - \\
\hline 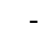 & zeer laag & - & - \\
\hline - & gemiddeld & - & - \\
\hline - & laag & - & - \\
\hline & gemiddeld & - & - \\
\hline- & gemiddeld & - & - \\
\hline & gemiddeld & - & - \\
\hline - & $\begin{array}{l}\text { gemiddeld } \\
\text { gemiddeld }\end{array}$ & $\begin{array}{l}- \\
-\end{array}$ & $\begin{array}{l}- \\
-\end{array}$ \\
\hline 38 & - & - & constant \\
\hline
\end{tabular}

Bron: CBS/ROA 
Tabel 1.13

Percentage flexibel werk per beroepssegment, Overijssel, gemiddelde 2000-2001

$\begin{array}{ccc}\text { Beroepssegment } & \% \text { typering } \begin{array}{l}\text { Overijssel trend } \\ \text { t.o.v. 1997-2001 } \\ \text { Nederland }\end{array} \\ & \end{array}$

Elementaire beroepen

Lagere niet-specialistische beroepen

Lagere docenten sportvakken

Lagere agrarische beroepen

Lagere wiskundige, natuurwetenschappelijke beroepen

Lagere technische beroepen

Lagere transportberoepen

Lagere (para)medische beroepen

Lagere administratieve, commerciële beroepen e.d.

Lagere beveiligingsberoepen

Lagere verzorgende beroepen

Middelbare docenten transport-, sportvakken

Middelbare agrarische beroepen

Middelbare wiskundige, natuurwetenschappelijke beroepen

Middelbare technische beroepen

Middelbare transportberoepen e.d.

Middelbare (para)medische beroepen

Middelbare administratieve, commerciële beroepen e.d.

Middelbare juridische, bestuurlijke beveiligingsberoepen

Middelbare taalkundige, culturele beroepen

Middelbare beroepen mbt. gedrag en maatschappij

Middelbare verzorgende beroepen e.d.

Hogere pedagogische beroepen

Hogere landbouwkundige beroepen

Hogere wiskundige, natuurwetenschappelijke beroepen

Hogere technische beroepen

Hogere transportberoepen

Hogere (para)medische beroepen

Hogere administratieve, commerciële beroepen

Hogere juridische, bestuurlijke, beveiligingsberoepen

Hogere taalkundige, culturele beroepen

Hogere beroepen mbt. gedrag en maatschappij e.d.

Hogere verzorgende beroepen

Managers (HBO werk- en denkniveau)

Wetenschappelijke pedagogische beroepen

Wetenschappelijke landbouwkundige beroepen

Wetensch. wiskundige, natuurwetenschappelijke beroepen

Wetenschappelijke technische beroepen

Wetenschappelijke (para)medische beroepen

Wetenschappelijke economische, administratieve beroepen

Wetenschappelijke juridische,bestuurlijke beroepen

Wetenschappelijke beroepen mbt. gedrag en maatschappij

Managers (wetenschappelijk werk- en denkniveau)

Totaal
23 hoog gemiddeld

- zeer hoog -

- zeer laag - -

- zeer laag -

8 gemiddeld zeer laag sterk dalend

- hoog

- hoog

6 hoog gemiddeld constant

- gemiddeld - -

- zeer hoog -

- zeer hoog -

- zeer laag - _ -

- zeer hoog - -

5 gemiddeld gemiddeld -

- hoog

8 gemiddeld hoog dalend

6 gemiddeld zeer laag dalend

- gemiddeld - -

- gemiddeld -

- gemiddeld -

- hoog -

10 hoog zeer hoog constant

- gemiddeld - -

- zeer laag - -

- gemiddeld - -

- zeer laag - $\quad$ -

- gemiddeld -

5 gemiddeld gemiddeld -

- laag - $\quad$ sterk stijgend

- gemiddeld -

- hoog - -

- zeer laag - _ -

- laag

- zeer laag -

- gemiddeld -

- zeer laag -

- laag

- laag

zeer laag

- gemiddeld -

- gemiddeld -

- laag -

9

dalend

Bron: CBS/ROA

Van flexibel werk is sprake bij uitzendkrachten, oproepkrachten, invalkrachten, contracten zonder een vast aantal arbeidsuren en indien geen vast dienstverband is overeengekomen. 
Tabel 1.14

Percentage deeltijdwerk per beroepssegment, Overijssel, gemiddelde 2000-2001

\begin{tabular}{|c|c|c|c|c|}
\hline Beroepssegment & $\%$ & typering & $\begin{array}{l}\text { Overijssel } \\
\text { t.o.v. } \\
\text { Nederland }\end{array}$ & $\begin{array}{l}\text { trend } \\
1997-2001\end{array}$ \\
\hline Elementaire beroepen & 47 & gemiddeld & gemiddeld & stijgend \\
\hline Lagere niet-specialistische beroepen & - & hoog & - & - \\
\hline Lagere docenten sportvakken & - & zeer hoog & - & - \\
\hline Lagere agrarische beroepen & - & gemiddeld & - & - \\
\hline Lagere wiskundige, natuurwetenschappelijke beroepen & - & gemiddeld & - & - \\
\hline Lagere technische beroepen & 12 & laag & laag & - \\
\hline Lagere transportberoepen & - & gemiddeld & - & - \\
\hline Lagere (para)medische beroepen & - & hoog & - & - \\
\hline Lagere administratieve, commerciële beroepen e.d. & 63 & hoog & hoog & constant \\
\hline Lagere beveiligingsberoepen & - & laag & & \\
\hline Lagere verzorgende beroepen & 72 & zeer hoog & gemiddeld & constant \\
\hline Middelbare docenten transport-, sportvakken & - & hoog & - & - \\
\hline Middelbare agrarische beroepen & - & gemiddeld & - & - \\
\hline Middelbare wiskundige, natuurwetenschappelijke beroepen & - & gemiddeld & - & - \\
\hline Middelbare technische beroepen & 7 & laag & laag & stijgend \\
\hline Middelbare transportberoepen e.d. & - & laag & - & - \\
\hline Middelbare (para)medische beroepen & 70 & zeer hoog & gemiddeld & constant \\
\hline Middelbare administratieve, commerciële beroepen e.d. & 28 & gemiddeld & laag & stijgend \\
\hline Middelbare juridische, bestuurlijke beveiligingsberoepen & - & gemiddeld & - & - \\
\hline Middelbare taalkundige, culturele beroepen & ـ & gemiddeld & _ & _ \\
\hline Middelbare beroepen mbt. gedrag en maatschappij & 59 & hoog & hoog & constant \\
\hline Middelbare verzorgende beroepen e.d. & 56 & hoog & gemiddeld & constant \\
\hline Hogere pedagogische beroepen & 52 & hoog & hoog & sterk stijgend \\
\hline Hogere landbouwkundige beroepen & - & zeer laag & - & - \\
\hline Hogere wiskundige, natuurwetenschappelijke beroepen & - & gemiddeld & - & - \\
\hline Hogere technische beroepen & - & zeer laag & - & - \\
\hline Hogere transportberoepen & - & zeer laag & - & - \\
\hline Hogere (para)medische beroepen & 62 & hoog & gemiddeld & - \\
\hline Hogere administratieve, commerciële beroepen & 19 & gemiddeld & zeer hoog & sterk stijgend \\
\hline Hogere juridische, bestuurlijke, beveiligingsberoepen & - & laag & - & - \\
\hline Hogere taalkundige, culturele beroepen & ـ & gemiddeld & _ & - \\
\hline Hogere beroepen mbt. gedrag en maatschappij e.d. & 38 & gemiddeld & zeer laag & constant \\
\hline Hogere verzorgende beroepen & - & zeer hoog & - & - \\
\hline Managers (HBO werk- en denkniveau) & - & laag & - & - \\
\hline Wetenschappelijke pedagogische beroepen & ـ & gemiddeld & _ & _ \\
\hline Wetenschappelijke landbouwkundige beroepen & - & hoog & - & - \\
\hline Wetensch. wiskundige, natuurwetenschappelijke beroepen & - & gemiddeld & - & - \\
\hline Wetenschappelijke technische beroepen & - & laag & - & - \\
\hline Wetenschappelijke (para)medische beroepen & - & laag & - & - \\
\hline Wetenschappelijke economische, administratieve beroepen & - & gemiddeld & _ & - \\
\hline Wetenschappelijke juridische,bestuurlijke beroepen & - & gemiddeld & - & - \\
\hline Wetenschappelijke beroepen mbt. gedrag en maatschappij & - & gemiddeld & - & - \\
\hline Managers (wetenschappelijk werk- en denkniveau) & - & laag & - & - \\
\hline Totaal & 31 & - & - & stijgend \\
\hline
\end{tabular}

Bron: CBS/ROA 
Tabel 1.15

Percentage zelfstandigen per beroepssegment, Overijssel, gemiddelde 2000-2001

\begin{tabular}{|c|c|c|c|c|}
\hline Beroepssegment & $\%$ & typering & $\begin{array}{l}\text { Overijssel } \\
\text { t.o.v. } \\
\text { Nederland }\end{array}$ & $\begin{array}{l}\text { trend } \\
1997-2001\end{array}$ \\
\hline Elementaire beroepen & 2 & laag & zeer laag & constant \\
\hline Lagere niet-specialistische beroepen & - & hoog & - & - \\
\hline Lagere docenten sportvakken & - & zeer laag & - & - \\
\hline Lagere agrarische beroepen & - & gemiddeld & - & - \\
\hline Lagere technische beroepen & 8 & gemiddeld & gemiddeld & - \\
\hline Lagere transportberoepen & - & laag & - & - \\
\hline Lagere (para)medische beroepen & - & zeer laag & - & - \\
\hline Lagere administratieve, commerciële beroepen e.d. & 2 & laag & gemiddeld & - \\
\hline Lagere beveiligingsberoepen & - & zeer laag & - & sterk stijgend \\
\hline Lagere verzorgende beroepen & - & gemiddeld & - & - \\
\hline Middelbare docenten transport-, sportvakken & - & zeer hoog & - & - \\
\hline Middelbare agrarische beroepen & 95 & zeer hoog & hoog & constant \\
\hline Middelbare wiskundige, natuurwetenschappelijke beroepen & - & zeer laag & - & - \\
\hline Middelbare technische beroepen & 10 & gemiddeld & gemiddeld & constant \\
\hline Middelbare transportberoepen e.d. & - & hoog & & - \\
\hline Middelbare (para)medische beroepen & 2 & laag & zeer laag & sterk dalend \\
\hline Middelbare administratieve, commerciële beroepen e.d. & 11 & gemiddeld & zeer hoog & constant \\
\hline Middelbare juridische, bestuurlijke beveiligingsberoepen & - & laag & - & - \\
\hline Middelbare taalkundige, culturele beroepen & - & hoog & - & - \\
\hline Middelbare beroepen mbt. gedrag en matschappij & - & zeer laag & - & - \\
\hline Middelbare verzorgende beroepen e.d. & 18 & hoog & laag & - \\
\hline Hogere pedagogische beroepen & 3 & laag & gemiddeld & sterk stijgend \\
\hline Hogere landbouwkundige beroepen & - & zeer laag & - & - \\
\hline Hogere wiskundige, natuurwetenschappelijke beroepen & - & zeer laag & - & - \\
\hline Hogere technische beroepen & - & gemiddeld & - & - \\
\hline Hogere transportberoepen & - & gemiddeld & - & constant \\
\hline Hogere (para)medische beroepen & - & hoog & - & - \\
\hline Hogere administratieve, commerciële beroepen & 24 & hoog & hoog & - \\
\hline Hogere juridische, bestuurlijke, beveiligingsberoepen & - & gemiddeld & - & - \\
\hline Hogere taalkundige, culturele beroepen & - & zeer hoog & - & - \\
\hline Hogere beroepen mbt. gedrag en maatschappij e.d. & - & gemiddeld & - & - \\
\hline Hogere verzorgende beroepen & - & laag & - & - \\
\hline Managers (HBO werk- en denkniveau) & - & gemiddeld & - & - \\
\hline Wetenschappelijke pedagogische beroepen & - & laag & - & - \\
\hline Wetenschappelijke landbouwkundige beroepen & - & gemiddeld & - & - \\
\hline Wetensch. wiskundige, natuurwetenschappelijke beroepen & - & gemiddeld & - & sterk stijgend \\
\hline Wetenschappelijke technische beroepen & - & gemiddeld & - & - \\
\hline Wetenschappelijke (para)medische beroepen & - & zeer hoog & - & - \\
\hline Wetenschappelijke economische, administratieve beroepen & - & hoog & - & - \\
\hline Wetenschappelijke juridische, bestuurlijke beroepen & - & gemiddeld & - & - \\
\hline Wetenschappelijke beroepen mbt. gedrag en maatschappij & - & gemiddeld & - & - \\
\hline Managers (wetenschappelijk werk- en denkniveau) & - & gemiddeld & - & - \\
\hline Totaal & 11 & - & - & constant \\
\hline
\end{tabular}

Bron: CBS/ROA 
Tabel 1.16

Aantal werkenden per opleidingstype, Overijssel, gemiddelde 2000-2001

\begin{tabular}{|c|c|c|c|}
\hline Opleidingstype & aantal & $\begin{array}{l}\text { Overijssel } \\
\text { t.o.v. } \\
\text { Nederland }\end{array}$ & $\begin{array}{l}\text { trend } \\
1997-2001\end{array}$ \\
\hline Basisonderwijs & 35.000 & & \\
\hline Basisonderwijs & 35.000 & gemiddeld & stijgend \\
\hline VMBO Theorie & 25.500 & & \\
\hline VMBO theorie & 25.500 & gemiddeld & constant \\
\hline VMBO Landbouw en natuurlijke omgeving & 4.500 & & \\
\hline VMBO landbouw en natuurlijke omgeving & 4.500 & hoog & sterk dalend \\
\hline VMBO Techniek & 40.000 & & \\
\hline $\begin{array}{l}\text { VMBO bouwtechniek } \\
\text { VMBO installatietechniek } \\
\text { VMBO mechanische techniek } \\
\text { VMBO fijnmechanische techniek } \\
\text { VMBO voertuigentechniek } \\
\text { VMBO elektrotechniek } \\
\text { VMBO grafische techniek } \\
\text { VMBO brood en banket } \\
\text { VMBO transport en logistiek }\end{array}$ & $\begin{array}{r}12.500 \\
- \\
9.500 \\
- \\
3.500 \\
6.000 \\
- \\
- \\
-\end{array}$ & $\begin{array}{l}\text { zeer hoog } \\
\text { gemiddeld } \\
\text { hoog } \\
\text { laag } \\
\text { hoog } \\
\text { zeer hoog } \\
\text { gemiddeld } \\
\text { gemiddeld } \\
\text { laag }\end{array}$ & $\begin{array}{l}\text { stijgend } \\
\text { constant } \\
- \\
- \\
- \\
\text { sterk stijgend } \\
- \\
\text { constant } \\
\text { constant }\end{array}$ \\
\hline VMBO Economie & 11.000 & & \\
\hline $\begin{array}{l}\text { VMBO administratie, handel en mode } \\
\text { VMBO consumptief en levensmiddelentechniek }\end{array}$ & $\begin{array}{l}8.000 \\
2.500\end{array}$ & $\begin{array}{l}\text { gemiddeld } \\
\text { hoog }\end{array}$ & $\begin{array}{l}\text { constant } \\
\text { sterk stijgend }\end{array}$ \\
\hline VMBO Zorg en welzijn & 13.000 & & \\
\hline VMBO (uiterlijke) verzorging & 13.000 & gemiddeld & constant \\
\hline VMBO Beveiliging & - & & \\
\hline VMBO beveiliging & - & gemiddeld & sterk stijgend \\
\hline HAVO/VWO & 22.500 & & \\
\hline HAVO/VWO & 22.500 & gemiddeld & sterk stijgend \\
\hline MBO Landbouw en natuurlijke omgeving & 12.000 & & \\
\hline $\begin{array}{l}\text { MBO voeding, natuur en milieu } \\
\text { MBO groene ruimte }\end{array}$ & $\begin{array}{l}9.000 \\
3.000\end{array}$ & $\begin{array}{l}\text { zeer hoog } \\
\text { zeer hoog }\end{array}$ & $\begin{array}{l}\text { dalend } \\
\text { sterk stijgend }\end{array}$ \\
\hline MBO Techniek & 62.000 & & \\
\hline $\begin{array}{l}\text { MBO laboratorium } \\
\text { MBO bouw } \\
\text { MBO grond-, weg- en waterbouw } \\
\text { MBO installatietechniek } \\
\text { MBO werktuigbouw en mechanische techniek } \\
\text { MBO fijnmechanische techniek } \\
\text { MBO motorvoertuigentechniek en tweewielers } \\
\text { MBO vliegtuigtechniek } \\
\text { MBO operationele techniek }\end{array}$ & $\begin{array}{r}15.000 \\
- \\
- \\
10.500 \\
- \\
5.500 \\
- \\
-\end{array}$ & $\begin{array}{l}\text { gemiddeld } \\
\text { zeer hoog } \\
\text { hoog } \\
\text { hoog } \\
\text { hoog } \\
\text { laag } \\
\text { hoog } \\
\text { zeer laag } \\
\text { hoog }\end{array}$ & $\begin{array}{l}\text { - } \\
- \\
- \\
\text { dalenstant } \\
- \\
\text { constant } \\
\text { constant } \\
\text { stijgend }\end{array}$ \\
\hline
\end{tabular}


Tabel 1.16 (vervolg)

Aantal werkenden per opleidingstype, Overijssel, gemiddelde 2000-2001

\begin{tabular}{|c|c|c|c|}
\hline Opleidingstype & aantal & $\begin{array}{l}\text { Overijssel } \\
\text { t.o.v. } \\
\text { Nederland }\end{array}$ & $\begin{array}{l}\text { trend } \\
1997-2001\end{array}$ \\
\hline
\end{tabular}

MBO Techniek (vervolg)

MBO elektrotechniek

MBO grafische techniek

MBO procestechniek

MBO brood en banket

MBO vervoer

MBO beweging en therapie

$\begin{array}{rll}13.500 & \text { hoog } & \text { constant } \\ 2.500 & \text { gemiddeld } & \text { constant } \\ \text { - } & \text { laag } & - \\ - & \text { gemiddeld } & \text { constant } \\ - & \text { laag } & - \\ - & \text { hoog } & \text { dalend }\end{array}$

MBO Dienstverlening en gezondheidszorg

48.500

MBO dokters-, tandarts- en dierenartsassistent

MBO apothekersassistent

$\mathrm{MBO}$ verpleging

MBO gezondheidstechniek

MBO sociaal-pedagogisch en welzijn

$\mathrm{MBO}$ verzorging

MBO uiterlijke verzorging

MBO horeca

\section{MBO Economie}

MBO administratie en logistiek

MBO handel

MBO secretariaat

MBO toerisme en recreatie

MBO facilitaire dienstverlening

MBO ICT

MBO geld, bank en belastingen

$M B O$ verzekeringswezen

MBO Openbare orde en veiligheid

MBO openbare orde en veiligheid

$\begin{aligned}- & \text { gemiddeld } \\ - & \text { gemiddeld } \\ 8.500 & \text { gemiddeld } \\ - & \text { zeer laag } \\ 7.500 & \text { zeer hoog } \\ 8.500 & \text { hoog } \\ 3.500 & \text { gemiddeld } \\ 5.500 & \text { gemiddeld }\end{aligned}$

sterk stijgend

sterk stijgend

stijgend

sterk dalend

stijgend

constant

5.500

stijgend

61.500

20.000

22.500

7.000

hoog

hoog

gemiddeld

gemiddeld

3.500

hoog

2.500 gemiddeld

gemiddeld

hoog

5.000

5.000

gemiddeld

constant

\section{HBO Onderwijs en tolk en vertaler}

24.500

HBO lerarenopleiding basisonderwijs

HBO lerarenopleiding talen

$\mathrm{HBO}$ lerarenopleiding natuur en techniek

HBO lerarenopleiding economie en maatschappij

HBO lerarenopleiding lichamelijke opvoeding

$\mathrm{HBO}$ lerarenopleiding medisch en verzorging

HBO lerarenopleiding expressie

$\mathrm{HBO}$ tolk en vertaler

14.000

hoog

- $\quad$ gemiddeld

stijgend

2.500 gemiddeld

-

sterk dalend

zeer hoog

-

constant

$2.500 \quad$ zeer hoog

stijgend

zeer laag

-

\section{HBO Landbouw}

HBO landbouw en veeteelt

HBO milieukunde en levensmiddelentechnologie

\section{HBO Techniek}

HBO laboratorium

HBO bouwkunde

HBO civiele techniek

$\mathrm{HBO}$ werktuigbouwkunde

HBO elektrotechniek

$\begin{array}{rll}- & \text { laag } & \text { sterk dalend } \\ - & \text { gemiddeld } & - \\ - & \text { gemiddeld } & \text { sterk stijgend } \\ 2.500 & \text { gemiddeld } & - \\ 2.500 & \text { gemiddeld } & \text { stijgend }\end{array}$


Tabel 1.16 (vervolg)

Aantal werkenden per opleidingstype, Overijssel, gemiddelde 2000-2001

\begin{tabular}{|c|c|c|c|}
\hline Opleidingstype & aantal & $\begin{array}{l}\text { Overijssel } \\
\text { t.o.v. } \\
\text { Nederland }\end{array}$ & $\begin{array}{l}\text { trend } \\
1997-2001\end{array}$ \\
\hline
\end{tabular}

HBO Techniek (vervolg)

HBO informatica

HBO chemische technologie

HBO vervoer en logistiek

2.500

gemiddeld

stijgend

HBO Paramedisch

zeer laag

sterk stijgend

$\mathrm{HBO}$ verpleegkunde

HBO (fysio)therapie

$\mathrm{HBO}$ voeding

$\mathrm{HBO}$ radiologie

7.500

4.000

gemiddeld

BO Economie

- laag

- laag

- hoog stijgend

HBO accountancy en bedrijfseconomie

HBO commerciële economie

HBO toerisme en recreatie

HBO recht en bestuur

$\mathrm{HBO}$ secretariaat

HBO bedrijfskunde

19.000

HBO Sociaal-cultureel

HBO communicatie en journalistiek

HBO maatschappelijk werk en hulpverlening

HBO personeel en arbeid

HBO bibliotheek en documentatie

HBO Kunst

4.500 gemiddeld

4.000 gemiddeld

laag

$\begin{array}{ll}\text { - } & \text { gemiddeld } \\ \text { - } & \text { gemiddeld }\end{array}$

tijgend

stijend

6.000 gemiddeld

constant

constant

stijgend

10.500

stijgend

\begin{tabular}{|c|c|}
\hline & laag \\
\hline 7.00 & $\begin{array}{l}\text { hoog } \\
\text { laag }\end{array}$ \\
\hline
\end{tabular}

2.500

HBO uitvoerende en beeldende kunsten

2.500

gemiddeld stijgend

HBO Openbare orde en veiligheid

HBO openbare orde en veiligheid

\section{WO Letteren en theologie}

WO letteren

WO theologie

WO Landbouw en milieukunde

WO landbouw en milieukunde

WO Techniek

WO wiskunde en natuurwetenschappen

WO bouwkunde

WO civiele techniek

WO werktuigbouwkunde

WO elektrotechniek

WO informatica en bestuurlijke informatiekunde

zeer laag

$\begin{array}{ll}\text { laag } & \begin{array}{l}\text { sterk stijgend } \\ \text { sterk dalend }\end{array} \\ \text { hoog } & \text { sterk stijgend }\end{array}$

6.000

3.500

gemiddeld

constant

- $\quad$ gemiddeld

sterk stijgend

laag

constant

- gemiddeld

sterk dalend

- laag

sterk dalend 
Tabel 1.16 (vervolg)

Aantal werkenden per opleidingstype, Overijssel, gemiddelde 2000-2001

\begin{tabular}{|c|c|c|c|}
\hline Opleidingstype & aantal & $\begin{array}{l}\text { Overijssel } \\
\text { t.o.v. } \\
\text { Nederland }\end{array}$ & $\begin{array}{l}\text { trend } \\
1997-2001\end{array}$ \\
\hline WO Medisch & 2.500 & & \\
\hline WO (dier)geneeskunde & - & laag & - \\
\hline WO tandheelkunde & - & gemiddeld & - \\
\hline WO farmacie en medische biologie & - & zeer laag & - \\
\hline WO Economie & 6.500 & & \\
\hline WO econom(etr)ie & - & zeer laag & - \\
\hline WO bedrijfskunde & - & laag & - \\
\hline WO accountancy en belastingen & - & zeer laag & - \\
\hline WO rechten en bestuurskunde & 3.500 & laag & - \\
\hline WO Sociaal-cultureel & 4.500 & & \\
\hline WO sociale wetenschappen & 4.000 & laag & sterk stijgend \\
\hline WO Kunst & - & & \\
\hline WO kunstwetenschappen & - & zeer laag & - \\
\hline Totaal & 460.000 & & \\
\hline
\end{tabular}

Bron: $\mathrm{CBS} / \mathrm{ROA}$ 
Tabel 1.17

Arbeidsmarktpositie potentiële beroepsbevolking naar opleidingstype, Overijssel, gemiddelde 2000-2001

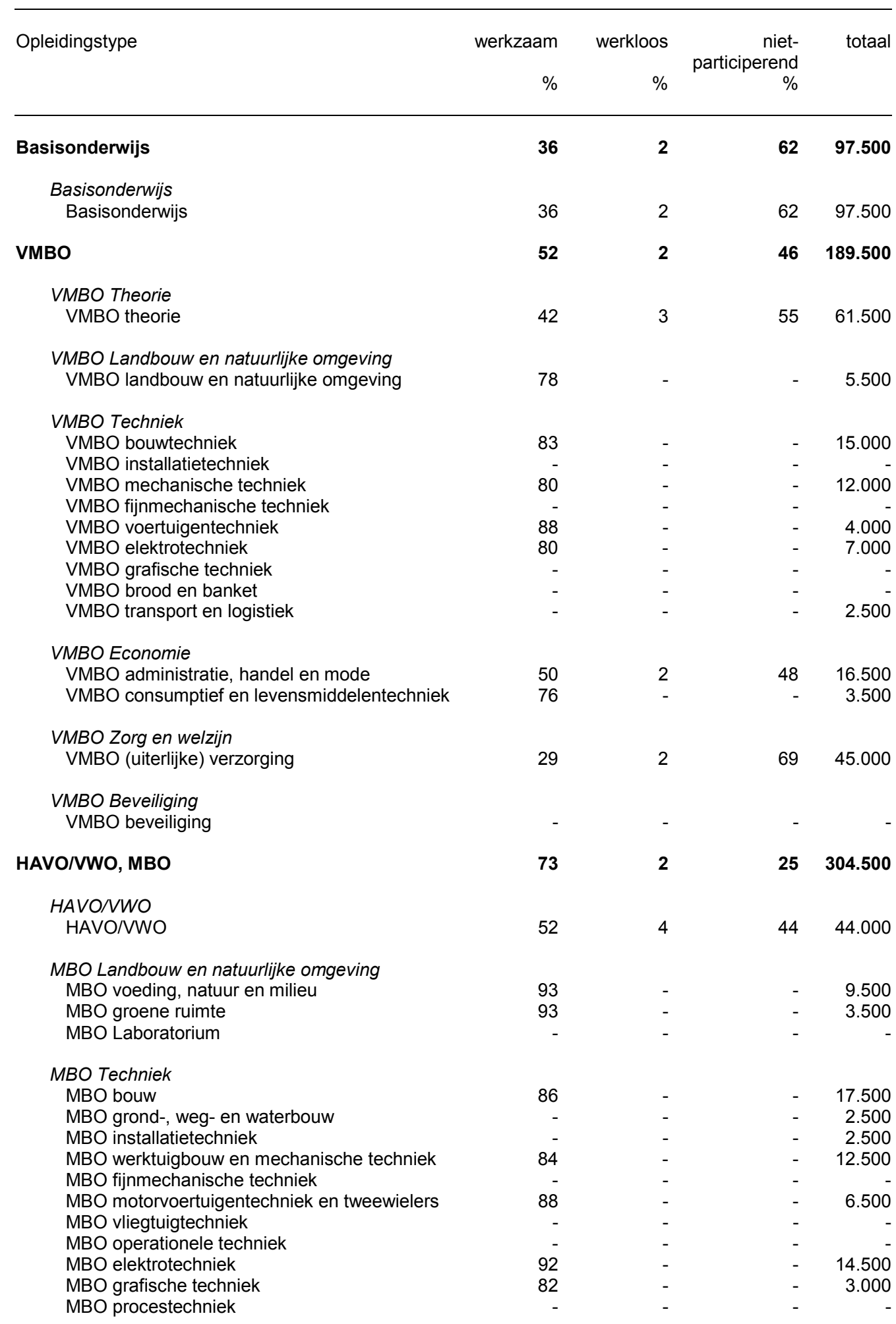


Tabel 1.17 (vervolg)

Arbeidsmarktpositie potentiële beroepsbevolking naar opleidingstype, Overijssel, gemiddelde 2000-2001

\begin{tabular}{lrrr}
\hline Opleidingstype & werkzaam & werkloos & $\begin{array}{r}\text { niet- } \\
\text { participerend } \\
\%\end{array}$ \\
& $\%$ & $\%$ & totaal
\end{tabular}

MBO Techniek (vervolg)

MBO brood en banke

MBO levensmiddelentechniek/vleesverwerking

$\mathrm{MBO}$ vervoer

MBO Dienstverlening en gezondheidszorg

MBO dokters-, tandarts- en dierenartsassistent

MBO apothekersassistent

$M B O$ verpleging

MBO gezondheidstechniek

MBO sociaal-pedagogisch en welzijn

$\mathrm{MBO}$ verzorging

MBO uiterlijke verzorging

MBO horeca

MBO beweging en therapie

MBO Economie

MBO administratie en logistiek

MBO hande

MBO secretariaat

MBO toerisme en recreatie

MBO facilitaire dienstverlening

MBO ICT

MBO geld, bank en belastingen

MBO verzekeringswezen

MBO Openbare orde en veiligheid

MBO openbare orde en veiligheid

13.500

11.500

31.500

5.500

6.500

2.500

HBO

HBO Onderwijs en tolk en vertaler

$\mathrm{HBO}$ lerarenopleiding basisonderwijs

HBO lerarenopleiding talen

HBO lerarenopleiding natuur en techniek

HBO lerarenopleiding economie en maatschappij

HBO lerarenopleiding lichamelijke opvoeding

HBO lerarenopleiding medisch en verzorging

HBO lerarenopleiding expressie

$\mathrm{HBO}$ tolk en vertaler

HBO Landbouw

HBO landbouw en veeteelt

HBO milieukunde en levensmiddelentechnologie

HBO Techniek

HBO laboratorium

HBO bouwkunde

HBO civiele techniek

HBO werktuigbouwkunde

HBO elektrotechniek

$\mathrm{HBO}$ informatica

$\mathrm{HBO}$ chemische technologie

HBO vervoer en logistiek

HBO Paramedisch

$\mathrm{HBO}$ verpleegkunde

HBO (fysio)therapie 
Tabel 1.17 (vervolg)

Arbeidsmarktpositie potentiële beroepsbevolking naar opleidingstype, Overijssel, gemiddelde 2000-2001

\begin{tabular}{|c|c|c|c|c|}
\hline Opleidingstype & $\begin{array}{r}\text { werkzaam } \\
\%\end{array}$ & $\begin{array}{r}\text { werkloos } \\
\%\end{array}$ & $\begin{array}{r}\text { niet- } \\
\text { participerend } \\
\%\end{array}$ & totaal \\
\hline \multicolumn{5}{|l|}{ HBO Paramedisch (vervolg) } \\
\hline HBO voeding & - & - & - & \\
\hline HBO radiologie & - & - & - & - \\
\hline \multicolumn{5}{|l|}{ HBO Economie } \\
\hline HBO accountancy en bedrijfseconomie & 92 & - & - & 4.500 \\
\hline HBO commerciële economie & 96 & - & - & 4.500 \\
\hline HBO toerisme en recreatie & - & - & - & \\
\hline HBO recht en bestuur & - & - & - & \\
\hline HBO secretariaat & - & - & - & 2.500 \\
\hline HBO bedrijfskunde & 81 & - & - & 7.000 \\
\hline \multicolumn{5}{|l|}{ HBO Sociaal-cultureel } \\
\hline HBO communicatie en journalistiek & - & - & - & \\
\hline HBO maatschappelijk werk en hulpverlening & 81 & - & - & 8.500 \\
\hline HBO personeel en arbeid & - & - & - & \\
\hline HBO bibliotheek en documentatie & - & - & - & - \\
\hline \multicolumn{5}{|l|}{ HBO Kunst } \\
\hline HBO uitvoerende en beeldende kunsten & 65 & - & - & 4.000 \\
\hline \multicolumn{5}{|l|}{ HBO Openbare orde en veiligheid } \\
\hline HBO openbare orde en veiligheid & - & - & - & - \\
\hline wo & 89 & 0 & 11 & 29.000 \\
\hline \multicolumn{5}{|l|}{ WO Letteren en theologie } \\
\hline WO letteren & - & - & - & - \\
\hline WO theologie & - & - & - & - \\
\hline \multicolumn{5}{|l|}{ WO Landbouw en milieukunde } \\
\hline WO landbouw en milieukunde & - & - & - & - \\
\hline \multicolumn{5}{|l|}{ WO Techniek } \\
\hline WO wiskunde en natuurwetenschappen & 90 & - & - & 3.500 \\
\hline WO bouwkunde & - & - & - & \\
\hline WO civiele techniek & - & - & - & - \\
\hline WO werktuigbouwkunde & - & - & - & - \\
\hline WO elektrotechniek & - & - & - & - \\
\hline WO informatica en bestuurlijke informatiekunde & - & - & - & - \\
\hline \multicolumn{5}{|l|}{ WO Medisch } \\
\hline WO (dier)geneeskunde & - & - & - & 2.500 \\
\hline WO tandheelkunde & - & - & - & \\
\hline WO farmacie en medische biologie & - & - & - & - \\
\hline \multicolumn{5}{|l|}{ WO Economie } \\
\hline WO econom(etr)ie & - & - & - & \\
\hline WO bedrijfskunde & - & - & - & 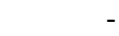 \\
\hline WO accountancy en belastingen & - & - & - & \\
\hline WO rechten en bestuurskunde & 96 & - & - & 3.500 \\
\hline \multicolumn{5}{|l|}{ WO Sociaal-cultureel } \\
\hline WO sociale wetenschappen & 85 & - & - & 4.500 \\
\hline \multicolumn{5}{|l|}{ WO Kunst } \\
\hline WO Kunstwetenschappen & - & - & - & - \\
\hline Totaal & 64 & 2 & 34 & 721.000 \\
\hline
\end{tabular}

Bron CBS/ROA 
Tabel 1.18

Percentage jongeren (15-29 jaar) per opleidingssector, Overijssel, gemiddelde 2000-2001

\begin{tabular}{|c|c|c|c|c|}
\hline Opleidingssector & $\%$ & typering & $\begin{array}{l}\text { Overijssel } \\
\text { t.o.v. } \\
\text { Nederland }\end{array}$ & $\begin{array}{l}\text { trend } \\
1997-2001\end{array}$ \\
\hline Basisonderwijs & 36 & zeer hoog & zeer hoog & stijgend \\
\hline VMBO theorie & 16 & gemiddeld & gemiddeld & constant \\
\hline VMBO landbouw en natuurlijke omgeving & - & zeer hoog & - & - \\
\hline VMBO techniek & 16 & gemiddeld & laag & constant \\
\hline VMBO economie & - & gemiddeld & - & - \\
\hline VMBO zorg en welzijn & 29 & hoog & hoog & stijgend \\
\hline VMBO beveiliging & - & laag & - & - \\
\hline HAVO/VWO & 7 & laag & laag & constant \\
\hline MBO landbouw en natuurlijke omgeving & - & gemiddeld & - & - \\
\hline MBO techniek & 20 & hoog & hoog & stijgend \\
\hline MBO dienstverlening en gezondheidszorg & 12 & laag & gemiddeld & sterk stijgend \\
\hline MBO economie & 16 & gemiddeld & laag & constant \\
\hline MBO openbare orde en veiligheid & - & gemiddeld & - & - \\
\hline $\mathrm{HBO}$ onderwijs en tolk en vertaler & 20 & gemiddeld & zeer laag & - \\
\hline HBO landbouw & - & gemiddeld & - & - \\
\hline HBO techniek & 21 & hoog & gemiddeld & sterk stijgend \\
\hline HBO paramedisch & - & laag & - & - \\
\hline HBO economie & 12 & laag & gemiddeld & - \\
\hline HBO sociaal-cultureel & - & gemiddeld & - & - \\
\hline HBO kunst & - & gemiddeld & - & - \\
\hline HBO openbare orde en veiligheid & - & zeer laag & - & - \\
\hline WO letteren en theologie & - & zeer hoog & - & - \\
\hline WO landbouw en milieukunde & - & laag & - & - \\
\hline WO techniek & - & hoog & - & - \\
\hline WO medisch & - & hoog & - & - \\
\hline WO economie & - & gemiddeld & - & - \\
\hline WO sociaal-cultureel & - & hoog & - & - \\
\hline WO kunst & & laag & - & - \\
\hline Totaal & 18 & - & - & constant \\
\hline
\end{tabular}

Bron: CBS/ROA 
Tabel 1.19

Percentage ouderen (50-64) per opleidingssector, Overijssel, gemiddelde 2000-2001

\begin{tabular}{|c|c|c|c|c|}
\hline Opleidingssector & $\%$ & typering & $\begin{array}{l}\text { Overijssel } \\
\text { t.o.v. } \\
\text { Nederland }\end{array}$ & $\begin{array}{l}\text { trend } \\
1997-2001\end{array}$ \\
\hline Basisonderwijs & 18 & gemiddeld & zeer laag & constant \\
\hline VMBO theorie & 40 & zeer hoog & gemiddeld & constant \\
\hline VMBO landbouw en natuurlijke omgeving & - & hoog & - & - \\
\hline VMBO techniek & 27 & gemiddeld & gemiddeld & constant \\
\hline VMBO economie & 30 & hoog & laag & dalend \\
\hline VMBO zorg en welzijn & - & laag & - & - \\
\hline VMBO beveiliging & - & laag & - & - \\
\hline HAVO/NWO & 46 & zeer hoog & gemiddeld & dalend \\
\hline MBO landbouw en natuurlijke omgeving & 29 & gemiddeld & laag & constant \\
\hline MBO techniek & 26 & gemiddeld & gemiddeld & dalend \\
\hline MBO dienstverlening en gezondheidszorg & 31 & hoog & gemiddeld & dalend \\
\hline MBO economie & 32 & hoog & hoog & dalend \\
\hline MBO openbare orde en veiligheid & - & gemiddeld & - & - \\
\hline HBO onderwijs en tolk en vertaler & 17 & gemiddeld & hoog & - \\
\hline HBO landbouw & - & laag & - & - \\
\hline HBO techniek & 30 & hoog & zeer hoog & constant \\
\hline HBO paramedisch & - & gemiddeld & - & - \\
\hline HBO economie & 29 & gemiddeld & laag & dalend \\
\hline HBO sociaal-cultureel & 29 & gemiddeld & hoog & constant \\
\hline HBO kunst & - & laag & - & - \\
\hline HBO openbare orde en veiligheid & - & laag & - & - \\
\hline WO letteren en theologie & - & zeer laag & - & - \\
\hline WO landbouw en milieukunde & - & laag & - & - \\
\hline WO techniek & - & hoog & - & - \\
\hline WO medisch & - & gemiddeld & - & - \\
\hline WO economie & - & gemiddeld & - & - \\
\hline WO sociaal-cultureel & - & laag & - & - \\
\hline WO kunst & - & zeer laag & - & - \\
\hline Totaal & 28 & - & - & constant \\
\hline
\end{tabular}

Bron: CBS/ROA 
Tabel 1.20

Percentage vrouwen per opleidingssector, Overijssel, gemiddelde 2000-2001

\begin{tabular}{|c|c|c|c|c|}
\hline Opleidingssector & $\%$ & typering & $\begin{array}{l}\text { Overijssel } \\
\text { t.o.v. } \\
\text { Nederland }\end{array}$ & $\begin{array}{l}\text { trend } \\
1997-2001\end{array}$ \\
\hline Basisonderwijs & 31 & gemiddeld & laag & stijgend \\
\hline VMBO theorie & 46 & gemiddeld & laag & constant \\
\hline VMBO landbouw en natuurlijke omgeving & - & laag & - & - \\
\hline VMBO techniek & 3 & zeer laag & gemiddeld & sterk stijgend \\
\hline VMBO economie & 46 & hoog & laag & constant \\
\hline VMBO zorg en welzijn & 94 & zeer hoog & gemiddeld & constant \\
\hline VMBO beveiliging & - & zeer laag & - & - \\
\hline HAVO/VWO & 43 & gemiddeld & gemiddeld & dalend \\
\hline MBO landbouw en natuurlijke omgeving & - & laag & - & - \\
\hline MBO techniek & 3 & laag & zeer laag & - \\
\hline MBO dienstverlening en gezondheidszorg & 85 & zeer hoog & hoog & constant \\
\hline MBO economie & 49 & hoog & gemiddeld & constant \\
\hline MBO openbare orde en veiligheid & - & laag & - & - \\
\hline $\mathrm{HBO}$ onderwijs en tolk en vertaler & 64 & hoog & hoog & stijgend \\
\hline HBO landbouw & - & gemiddeld & - & - \\
\hline HBO techniek & - & laag & - & - \\
\hline HBO paramedisch & 73 & zeer hoog & gemiddeld & constant \\
\hline HBO economie & 38 & gemiddeld & gemiddeld & stijgend \\
\hline HBO sociaal-cultureel & 68 & hoog & zeer hoog & constant \\
\hline HBO kunst & - & gemiddeld & - & - \\
\hline HBO openbare orde en veiligheid & - & laag & - & - \\
\hline WO letteren en theologie & - & gemiddeld & - & - \\
\hline WO landbouw en milieukunde & - & laag & - & - \\
\hline WO techniek & - & laag & - & - \\
\hline WO medisch & - & gemiddeld & - & - \\
\hline WO economie & - & gemiddeld & - & - \\
\hline WO sociaal-cultureel & - & hoog & - & - \\
\hline WO kunst & - & gemiddeld & - & - \\
\hline Totaal & 38 & - & - & constant \\
\hline
\end{tabular}

Bron: CBS/ROA 
Tabel 1.21

Percentage flexibel werk per opleidingssector, Overijssel, gemiddelde 2000-2001

\begin{tabular}{|c|c|c|c|c|}
\hline Opleidingssector & $\%$ & typering & $\begin{array}{l}\text { Overijssel } \\
\text { t.o.v. } \\
\text { Nederland }\end{array}$ & $\begin{array}{l}\text { trend } \\
1997-2001\end{array}$ \\
\hline Basisonderwijs & 13 & hoog & laag & - \\
\hline VMBO theorie & 20 & hoog & hoog & stijgend \\
\hline VMBO landbouw en natuurlijke omgeving & - & gemiddeld & - & - \\
\hline VMBO techniek & 8 & gemiddeld & gemiddeld & - \\
\hline VMBO economie & - & gemiddeld & - & - \\
\hline VMBO zorg en welzijn & - & hoog & - & - \\
\hline VMBO beveiliging & - & laag & - & - \\
\hline HAVO/VWO & 22 & zeer hoog & gemiddeld & dalend \\
\hline MBO landbouw en natuurlijke omgeving & - & gemiddeld & - & - \\
\hline MBO techniek & 3 & laag & zeer laag & sterk dalend \\
\hline MBO dienstverlening en gezondheidszorg & 9 & gemiddeld & gemiddeld & sterk dalend \\
\hline MBO economie & 8 & gemiddeld & hoog & dalend \\
\hline MBO openbare orde en veiligheid & - & laag & - & - \\
\hline HBO onderwijs en tolk en vertaler & 10 & gemiddeld & zeer hoog & stijgend \\
\hline HBO landbouw & - & gemiddeld & - & - \\
\hline HBO techniek & - & laag & - & - \\
\hline HBO paramedisch & - & gemiddeld & - & - \\
\hline HBO economie & 6 & gemiddeld & laag & - \\
\hline HBO sociaal-cultureel & - & hoog & - & - \\
\hline HBO kunst & - & hoog & - & - \\
\hline HBO openbare orde en veiligheid & - & laag & - & - \\
\hline WO letteren en theologie & - & gemiddeld & - & - \\
\hline WO landbouw en milieukunde & - & laag & - & - \\
\hline WO techniek & - & gemiddeld & - & - \\
\hline WO medisch & - & zeer laag & - & - \\
\hline WO economie & - & laag & - & - \\
\hline WO sociaal-cultureel & - & laag & - & - \\
\hline WO kunst & - & zeer laag & - & - \\
\hline Totaal & 9 & - & - & dalend \\
\hline
\end{tabular}

Bron: CBS/ROA

Van flexibel werk is sprake bij uitzendkrachten, oproepkrachten, invalkrachten, contracten zonder een vast aantal arbeidsuren en indien geen vast dienstverband is overeengekomen. 
Tabel 1.22

Percentage deeltijdwerk per opleidingssector, Overijssel, gemiddelde 2000-2001

\begin{tabular}{|c|c|c|c|c|}
\hline Opleidingssector & $\%$ & typering & $\begin{array}{l}\text { Overijssel } \\
\text { t.o.v. } \\
\text { Nederland }\end{array}$ & $\begin{array}{l}\text { trend } \\
1997-2001\end{array}$ \\
\hline Basisonderwijs & 32 & gemiddeld & gemiddeld & stijgend \\
\hline VMBO theorie & 44 & hoog & gemiddeld & stijgend \\
\hline VMBO landbouw en natuurlijke omgeving & - & laag & - & - \\
\hline VMBO techniek & 9 & laag & gemiddeld & constant \\
\hline VMBO economie & 38 & gemiddeld & gemiddeld & dalend \\
\hline VMBO zorg en welzijn & 80 & zeer hoog & hoog & constant \\
\hline VMBO beveiliging & - & zeer laag & - & - \\
\hline HAVO/VWO & 42 & gemiddeld & gemiddeld & constant \\
\hline MBO landbouw en natuurlijke omgeving & - & gemiddeld & - & - \\
\hline MBO techniek & 6 & zeer laag & zeer laag & constant \\
\hline MBO dienstverlening en gezondheidszorg & 68 & zeer hoog & hoog & stijgend \\
\hline MBO economie & 28 & gemiddeld & laag & constant \\
\hline MBO openbare orde en veiligheid & - & laag & - & - \\
\hline $\mathrm{HBO}$ onderwijs en tolk en vertaler & 53 & hoog & zeer hoog & sterk stijgend \\
\hline HBO landbouw & - & gemiddeld & - & - \\
\hline HBO techniek & - & laag & - & - \\
\hline HBO paramedisch & 53 & hoog & laag & - \\
\hline HBO economie & 18 & gemiddeld & laag & stijgend \\
\hline HBO sociaal-cultureel & 51 & hoog & hoog & stijgend \\
\hline HBO kunst & - & hoog & - & - \\
\hline HBO openbare orde en veiligheid & - & laag & - & - \\
\hline WO letteren en theologie & - & gemiddeld & - & - \\
\hline WO landbouw en milieukunde & - & laag & - & - \\
\hline WO techniek & - & laag & - & - \\
\hline WO medisch & - & laag & - & - \\
\hline WO economie & - & gemiddeld & - & - \\
\hline WO sociaal-cultureel & - & hoog & - & - \\
\hline WO kunst & - & gemiddeld & - & - \\
\hline Totaal & 31 & - & - & stijgend \\
\hline
\end{tabular}

Bron: CBS/ROA 
Tabel 1.23

Percentage zelfstandigen per opleidingssector, Overijssel, gemiddelde 2000-2001

\begin{tabular}{|c|c|c|c|c|}
\hline Opleidingssector & $\%$ & typering & $\begin{array}{l}\text { Overijssel } \\
\text { t.o.v. } \\
\text { Nederland }\end{array}$ & $\begin{array}{l}\text { trend } \\
1997-2001\end{array}$ \\
\hline Basisonderwijs & 10 & gemiddeld & gemiddeld & dalend \\
\hline VMBO theorie & 8 & gemiddeld & laag & constant \\
\hline VMBO landbouw en natuurlijke omgeving & - & hoog & - & - \\
\hline VMBO techniek & 9 & gemiddeld & hoog & stijgend \\
\hline VMBO economie & - & gemiddeld & - & - \\
\hline VMBO zorg en welzijn & - & hoog & - & - \\
\hline VMBO beveiliging & - & laag & - & sterk stijgend \\
\hline HAVO/VWO & 9 & gemiddeld & gemiddeld & sterk dalend \\
\hline MBO landbouw en natuurlijke omgeving & 34 & zeer hoog & gemiddeld & sterk dalend \\
\hline MBO techniek & 10 & gemiddeld & gemiddeld & constant \\
\hline MBO dienstverlening en gezondheidszorg & 8 & gemiddeld & laag & - \\
\hline MBO economie & 15 & gemiddeld & zeer hoog & stijgend \\
\hline MBO openbare orde en veiligheid & - & zeer laag & - & - \\
\hline HBO onderwijs en tolk en vertaler & 5 & laag & zeer laag & - \\
\hline HBO landbouw & - & hoog & - & - \\
\hline HBO techniek & - & gemiddeld & - & - \\
\hline HBO paramedisch & - & gemiddeld & - & - \\
\hline HBO economie & 8 & laag & laag & - \\
\hline HBO sociaal-cultureel & - & laag & - & - \\
\hline HBO kunst & - & zeer hoog & - & - \\
\hline HBO openbare orde en veiligheid & - & gemiddeld & - & - \\
\hline WO letteren en theologie & - & laag & - & - \\
\hline WO landbouw en milieukunde & - & laag & - & - \\
\hline WO techniek & - & gemiddeld & - & - \\
\hline WO medisch & - & zeer hoog & - & - \\
\hline WO economie & - & hoog & - & - \\
\hline WO sociaal-cultureel & - & hoog & - & - \\
\hline WO kunst & - & hoog & - & - \\
\hline Totaal & 11 & - & - & constant \\
\hline
\end{tabular}

Bron: CBS/ROA 
2 Leerlingen en gediplomeerden in Overijssel 

Tabel 2.1

Aantal leerlingen in het VMBO en MBO per opleidingstype, Overijssel, 2000 en 2001

\begin{tabular}{|c|c|c|c|}
\hline Opleidingstype & $\begin{array}{r}\text { aantal } \\
2000\end{array}$ & $\begin{array}{r}\text { aantal } \\
2001\end{array}$ & $\begin{array}{l}\text { Overijssel t.o.v. } \\
\text { Nederland } 2001\end{array}$ \\
\hline \multicolumn{4}{|l|}{ VMBO Theorie } \\
\hline VMBO theorie & 75.120 & 72.320 & gemiddeld \\
\hline \multicolumn{4}{|l|}{ VMBO Landbouw en natuurlijke omgeving } \\
\hline VMBO landbouw en natuurlijke omgeving & 1.210 & 2.870 & - \\
\hline \multicolumn{4}{|l|}{ VMBO Techniek } \\
\hline VMBO bouwtechniek & 3.160 & 4.350 & hoog \\
\hline VMBO installatietechniek & 270 & 230 & laag \\
\hline VMBO mechanische techniek & 1.500 & 1.450 & gemiddeld \\
\hline VMBO fijnmechanische techniek & - & - & - \\
\hline VMBO voertuigentechniek & 860 & 980 & laag \\
\hline VMBO elektrotechniek & 1.410 & 1.790 & gemiddeld \\
\hline VMBO grafische techniek & 140 & 190 & laag \\
\hline VMBO brood en banket & 80 & 100 & laag \\
\hline VMBO transport en logistiek & 140 & 240 & laag \\
\hline \multicolumn{4}{|l|}{ VMBO Economie } \\
\hline VMBO administratie, handel en mode & 5.430 & 8.160 & gemiddeld \\
\hline VMBO consumptief en levensmiddelentechniek & 870 & 1.310 & gemiddeld \\
\hline \multicolumn{4}{|l|}{ VMBO Zorg en welzijn } \\
\hline VMBO (uiterlijke) verzorging & 4.830 & 5.590 & gemiddeld \\
\hline \multicolumn{4}{|l|}{ VMBO Beveiliging } \\
\hline VMBO beveiliging & 480 & 480 & gemiddeld \\
\hline \multicolumn{4}{|l|}{ HAVONWWO } \\
\hline HAVO/VWO & 41.270 & 41.590 & laag \\
\hline \multicolumn{4}{|l|}{ MBO Landbouw } \\
\hline MBO voeding, natuur en milieu & 1.480 & 2.110 & - \\
\hline MBO groene ruimte & 890 & 1.170 & - \\
\hline \multicolumn{4}{|l|}{ MBO Techniek } \\
\hline MBO laboratorium & 240 & 230 & zeer laag \\
\hline MBO bouw & 3.280 & 3.180 & hoog \\
\hline MBO grond-, weg- en waterbouw & 580 & 490 & hoog \\
\hline MBO installatietechniek & 690 & 720 & gemiddeld \\
\hline MBO werktuigbouw en mechanische techniek & 1.360 & 1.220 & gemiddeld \\
\hline MBO fijnmechanische techniek & 90 & 70 & zeer laag \\
\hline MBO motorvoertuigentechniek en tweewielers & 1.250 & 1.260 & gemiddeld \\
\hline MBO vliegtuigtechniek & 20 & 70 & laag \\
\hline MBO operationele techniek & 380 & 330 & gemiddeld \\
\hline MBO elektrotechniek & 2.200 & 2.140 & hoog \\
\hline MBO grafische techniek & 970 & 940 & hoog \\
\hline MBO procestechniek & 150 & 110 & zeer laag \\
\hline MBO brood en banket & 210 & 260 & gemiddeld \\
\hline MBO levensmiddelentechniek/vleesverwerking & & & \\
\hline MBO vervoer & 720 & 720 & gemiddeld \\
\hline \multicolumn{4}{|l|}{ MBO Dienstverlening en gezondheidszorg } \\
\hline MBO dokters-, tandarts- en dierenartsassistent & 310 & 320 & gemiddeld \\
\hline MBO apothekersassistent & 180 & 170 & laag \\
\hline MBO verpleging & 1.160 & 1.280 & gemiddeld \\
\hline MBO gezondheidstechniek & 100 & 110 & hoog \\
\hline MBO sociaal-pedagogisch en welzijn & 3.530 & 3.360 & gemiddeld \\
\hline MBO verzorging & 2.630 & 2.750 & gemiddeld \\
\hline
\end{tabular}


Tabel 2.1 (vervolg)

Aantal leerlingen in het VMBO en MBO per opleidingstype, Overijssel, 2000 en 2001

\begin{tabular}{lrrl}
\hline Opleidingstype & aantal & $\begin{array}{r}\text { aantal } \\
2001\end{array}$ & $\begin{array}{l}\text { Overijssel t.o.v. } \\
\text { Nederland 2001 }\end{array}$ \\
& 2000 & & \\
\hline MBO Dienstverlening en gezondheidszorg (vervolg) & & & \\
MBO uiterlijke verzorging & 870 & 920 & laag \\
MBO horeca & 1.520 & 1.330 & gemiddeld \\
MBO beweging en therapie & - & - & - \\
MBO Economie & & & \\
MBO administratie en logistiek & 3.060 & 3.500 & hoog \\
MBO handel & 4.860 & 4.880 & hoog \\
MBO secretariaat & 850 & 830 & gemiddeld \\
MBO toerisme en recreatie & 1.240 & 1.230 & hoog \\
MBO facilitaire dienstverlening & 10 & 10 & hoog \\
MBO ICT & 1.740 & 2.140 & gemiddeld \\
MBO geld, bank en belastingen & 260 & 150 & gemiddeld \\
MBO verzekeringswezen & 110 & 70 & zeer hoog \\
MBO Openbare orde en veiligheid & & & \\
MBO openbare orde en veiligheid & 30 & 20 & laag \\
\hline
\end{tabular}


Tabel 2.3

Aantal leerlingen (BOL) in het MBO per opleidingstype, Overijssel, 2000 en 2001

\begin{tabular}{|c|c|c|c|}
\hline Opleidingstype & $\begin{array}{r}\text { aantal } \\
2000\end{array}$ & $\begin{array}{r}\text { aantal } \\
2001\end{array}$ & $\begin{array}{l}\text { Overijssel t.o.v. } \\
\text { Nederland } 2001\end{array}$ \\
\hline \multicolumn{4}{|l|}{ MBO Landbouw } \\
\hline MBO voeding, natuur en milieu & 1.110 & 1.670 & - \\
\hline MBO groene ruimte & 470 & 590 & - \\
\hline \multicolumn{4}{|l|}{ MBO Techniek } \\
\hline MBO laboratorium & 220 & 230 & laag \\
\hline MBO bouw & 1.290 & 1.150 & hoog \\
\hline MBO grond-, weg- en waterbouw & 260 & 170 & hoog \\
\hline MBO installatietechniek & 50 & 50 & laag \\
\hline MBO werktuigbouw en mechanische techniek & 660 & 550 & gemiddeld \\
\hline MBO fijnmechanische techniek & 70 & 60 & zeer laag \\
\hline MBO motorvoertuigentechniek en tweewielers & 290 & 310 & laag \\
\hline MBO vliegtuigtechniek & - & - & - \\
\hline MBO operationele techniek & - & - & - \\
\hline MBO elektrotechniek & 930 & 820 & gemiddeld \\
\hline MBO grafische techniek & 800 & 780 & hoog \\
\hline MBO procestechniek & 40 & 10 & zeer laag \\
\hline MBO brood en banket & 30 & 100 & gemiddeld \\
\hline MBO levensmiddelentechniek/vleesverwerking & - & - & - \\
\hline MBO vervoer & 330 & 390 & laag \\
\hline \multicolumn{4}{|l|}{ MBO Dienstverlening en gezondheidszorg } \\
\hline MBO dokters-, tandarts- en dierenartsassistent & 310 & 320 & gemiddeld \\
\hline MBO apothekersassistent & 180 & 170 & gemiddeld \\
\hline $\mathrm{MBO}$ verpleging & 560 & 620 & hoog \\
\hline MBO gezondheidstechniek & & & - \\
\hline MBO sociaal-pedagogisch en welzijn & 3.200 & 2.940 & gemiddeld \\
\hline MBO verzorging & 1.790 & 1.570 & gemiddeld \\
\hline MBO uiterlijke verzorging & 480 & 480 & laag \\
\hline MBO horeca & 900 & 760 & gemiddeld \\
\hline MBO beweging en therapie & - & - & - \\
\hline \multicolumn{4}{|l|}{ MBO Economie } \\
\hline MBO administratie en logistiek & 2.750 & 2.580 & gemiddeld \\
\hline MBO handel & 3.720 & 3.520 & hoog \\
\hline MBO secretariaat & 780 & 760 & gemiddeld \\
\hline MBO toerisme en recreatie & 1.120 & 1.150 & hoog \\
\hline MBO facilitaire dienstverlening & - & & - \\
\hline MBO ICT & 1.640 & 2.090 & gemiddeld \\
\hline MBO geld, bank en belastingen & 250 & 150 & gemiddeld \\
\hline MBO verzekeringswezen & 110 & 70 & zeer hoog \\
\hline \multicolumn{4}{|l|}{ MBO Openbare orde en veiligheid } \\
\hline MBO openbare orde en veiligheid & 30 & 20 & gemiddeld \\
\hline
\end{tabular}


Tabel 2.4

Percentage vrouwelijke leerlingen in het VMBO en MBO per opleidingstype, Overijssel, 2000 en 2001

\begin{tabular}{|c|c|c|c|}
\hline Opleidingstype & $\begin{array}{r}\% \\
2000\end{array}$ & $\begin{array}{r}\% \\
2001\end{array}$ & $\begin{array}{l}\text { typering t.o.v. } \\
\text { Nederland } 2001\end{array}$ \\
\hline \multicolumn{4}{|l|}{ VMBO Theorie } \\
\hline VMBO theorie & 47 & 47 & gemiddeld \\
\hline \multicolumn{4}{|l|}{ VMBO Landbouw en natuurlijke omgeving } \\
\hline VMBO landbouw en natuurlijke omgeving & 48 & 45 & - \\
\hline \multicolumn{4}{|l|}{ VMBO Techniek } \\
\hline VMBO bouwtechniek & 42 & 47 & hoog \\
\hline VMBO installatietechniek & 49 & 45 & laag \\
\hline VMBO mechanische techniek & 41 & 47 & gemiddeld \\
\hline VMBO fijnmechanische techniek & - & - & - \\
\hline VMBO voertuigentechniek & 27 & 40 & gemiddeld \\
\hline VMBO elektrotechniek & 26 & 40 & gemiddeld \\
\hline VMBO grafische techniek & 41 & 51 & gemiddeld \\
\hline VMBO brood en banket & 46 & 51 & laag \\
\hline VMBO transport en logistiek & 22 & 42 & hoog \\
\hline \multicolumn{4}{|l|}{ VMBO Economie } \\
\hline VMBO administratie, handel en mode & 54 & 55 & gemiddeld \\
\hline VMBO consumptief en levensmiddelentechniek & 32 & 57 & hoog \\
\hline \multicolumn{4}{|l|}{ VMBO Zorg en welzijn } \\
\hline VMBO (uiterlijke) verzorging & 82 & 75 & gemiddeld \\
\hline \multicolumn{4}{|l|}{ VMBO Beveiliging } \\
\hline VMBO beveiliging & 32 & 26 & gemiddeld \\
\hline \multicolumn{4}{|l|}{ HAVO/VWO } \\
\hline HAVO/VWO & 56 & 56 & laag \\
\hline \multicolumn{4}{|l|}{ MBO Landbouw } \\
\hline MBO voeding, natuur en milieu & 59 & 55 & - \\
\hline MBO groene ruimte & 8 & 7 & - \\
\hline \multicolumn{4}{|l|}{ MBO Techniek } \\
\hline MBO laboratorium & 47 & 46 & laag \\
\hline MBO bouw & 9 & 8 & zeer hoog \\
\hline MBO grond-, weg- en waterbouw & 1 & 0 & laag \\
\hline MBO installatietechniek & 0 & 0 & laag \\
\hline MBO werktuigbouw en mechanische techniek & 1 & 2 & hoog \\
\hline MBO fijnmechanische techniek & 13 & 8 & zeer laag \\
\hline MBO motorvoertuigentechniek en tweewielers & 1 & 1 & gemiddeld \\
\hline MBO vliegtuigtechniek & 0 & 1 & zeer laag \\
\hline MBO operationele techniek & 7 & 9 & zeer hoog \\
\hline MBO elektrotechniek & 1 & 1 & gemiddeld \\
\hline MBO grafische techniek & 28 & 28 & gemiddeld \\
\hline MBO procestechniek & 6 & 4 & zeer laag \\
\hline MBO brood en banket & 20 & 19 & gemiddeld \\
\hline MBO levensmiddelentechniek/vleesverwerking & - & - & - \\
\hline MBO vervoer & 15 & 17 & gemiddeld \\
\hline \multicolumn{4}{|l|}{ MBO Dienstverlening en gezondheidszorg } \\
\hline MBO dokters-, tandarts- en dierenartsassistent & 100 & 100 & gemiddeld \\
\hline MBO apothekersassistent & 98 & 99 & gemiddeld \\
\hline MBO verpleging & 87 & 87 & gemiddeld \\
\hline MBO gezondheidstechniek & 70 & 62 & hoog \\
\hline MBO sociaal-pedagogisch en welzijn & 83 & 82 & gemiddeld \\
\hline
\end{tabular}


Tabel 2.4 (vervolg)

Percentage vrouwelijke leerlingen in het VMBO en MBO per opleidingstype, Overijssel, 2000 en 2001

\begin{tabular}{|c|c|c|c|}
\hline Opleidingstype & $\begin{array}{r}\% \\
2000\end{array}$ & $\begin{array}{r}\% \\
2001\end{array}$ & $\begin{array}{l}\text { typering t.o.v. } \\
\text { Nederland } 2001\end{array}$ \\
\hline \multicolumn{4}{|c|}{ MBO Dienstverlening en gezondheidszorg (vervolg) } \\
\hline MBO verzorging & 91 & 92 & gemiddeld \\
\hline MBO uiterlijke verzorging & 99 & 99 & laag \\
\hline MBO horeca & 42 & 39 & gemiddeld \\
\hline MBO beweging en therapie & - & - & - \\
\hline \multicolumn{4}{|l|}{ MBO Economie } \\
\hline MBO administratie en logistiek & 37 & 46 & hoog \\
\hline MBO handel & 55 & 54 & hoog \\
\hline MBO secretariaat & 99 & 99 & gemiddeld \\
\hline MBO toerisme en recreatie & 79 & 83 & hoog \\
\hline MBO facilitaire dienstverlening & 0 & 0 & zeer laag \\
\hline MBO ICT & 3 & 3 & laag \\
\hline MBO geld, bank en belastingen & 47 & 45 & gemiddeld \\
\hline MBO verzekeringswezen & 52 & 54 & zeer hoog \\
\hline \multicolumn{4}{|l|}{ MBO Openbare orde en veiligheid } \\
\hline MBO openbare orde en veiligheid & 12 & 33 & laag \\
\hline
\end{tabular}


Tabel 2.5

Aantal gediplomeerden in het VMBO en MBO per opleidingstype, Overijssel, 2000 en 2001

\begin{tabular}{|c|c|c|c|}
\hline Opleidingstype & $\begin{array}{r}\text { aantal } \\
2000\end{array}$ & $\begin{array}{r}\text { aantal } \\
2001\end{array}$ & $\begin{array}{l}\text { Overijssel t.o.v. } \\
\text { Nederland } 2001\end{array}$ \\
\hline \multicolumn{4}{|l|}{ VMBO Theorie } \\
\hline VMBO theorie & 5.200 & 5.000 & gemiddeld \\
\hline \multicolumn{4}{|l|}{ VMBO Landbouw en natuurlijke omgeving } \\
\hline VMBO landbouw en natuurlijke omgeving & 180 & 510 & - \\
\hline \multicolumn{4}{|l|}{ VMBO Techniek } \\
\hline VMBO bouwtechniek & 1.000 & 925 & hoog \\
\hline VMBO installatietechniek & 75 & 75 & gemiddeld \\
\hline VMBO mechanische techniek & 650 & 700 & hoog \\
\hline VMBO fijnmechanische techniek & 0 & 0 & - \\
\hline VMBO voertuigentechniek & 300 & 325 & gemiddeld \\
\hline VMBO elektrotechniek & 500 & 475 & gemiddeld \\
\hline VMBO grafische techniek & 25 & 50 & laag \\
\hline VMBO brood en banket & 50 & 50 & gemiddeld \\
\hline VMBO transport en logistiek & 75 & 100 & hoog \\
\hline \multicolumn{4}{|l|}{ VMBO Economie } \\
\hline VMBO administratie, handel en mode & 1.250 & 1.200 & gemiddeld \\
\hline VMBO consumptief en levensmiddelentechniek & 300 & 325 & gemiddeld \\
\hline \multicolumn{4}{|l|}{ VMBO Zorg en welzijn } \\
\hline VMBO (uiterlijke) verzorging & 1.875 & 1.900 & gemiddeld \\
\hline \multicolumn{4}{|l|}{ VMBO Beveiliging } \\
\hline VMBO beveiliging & 150 & 100 & laag \\
\hline \multicolumn{4}{|l|}{ HAVO/VWO } \\
\hline HAVO/VWO & 7.650 & 6.350 & gemiddeld \\
\hline \multicolumn{4}{|l|}{ MBO Landbouw } \\
\hline MBO voeding, natuur en milieu & 650 & 630 & - \\
\hline MBO groene ruimte & 310 & 360 & - \\
\hline \multicolumn{4}{|l|}{ MBO Techniek } \\
\hline MBO laboratorium & 50 & 50 & laag \\
\hline MBO bouw & 1.120 & 1.080 & hoog \\
\hline MBO grond-, weg- en waterbouw & 250 & 230 & hoog \\
\hline MBO installatietechniek & 300 & 220 & gemiddeld \\
\hline MBO werktuigbouw en mechanische techniek & 390 & 400 & gemiddeld \\
\hline MBO fijnmechanische techniek & 20 & 30 & laag \\
\hline MBO motorvoertuigentechniek en tweewielers & 410 & 440 & gemiddeld \\
\hline MBO vliegtuigtechniek & 0 & 0 & zeer laag \\
\hline MBO operationele techniek & 40 & 70 & hoog \\
\hline MBO elektrotechniek & 540 & 500 & gemiddeld \\
\hline MBO grafische techniek & 230 & 240 & zeer hoog \\
\hline MBO procestechniek & 40 & 10 & laag \\
\hline MBO brood en banket & 50 & 40 & gemiddeld \\
\hline MBO levensmiddelentechniek/vleesverwerking & & & - \\
\hline MBO vervoer & 210 & 170 & laag \\
\hline \multicolumn{4}{|l|}{ MBO Dienstverlening en gezondheidszorg } \\
\hline MBO dokters-, tandarts- en dierenartsassistent & 110 & 90 & gemiddeld \\
\hline MBO apothekersassistent & 70 & 50 & gemiddeld \\
\hline MBO verpleging & 10 & 210 & laag \\
\hline MBO gezondheidstechniek & 60 & 60 & hoog \\
\hline MBO sociaal-pedagogisch en welzijn & 950 & 1.030 & gemiddeld \\
\hline MBO verzorging & 930 & 1.010 & gemiddeld \\
\hline
\end{tabular}


Tabel 2.5 (vervolg)

Aantal gediplomeerden in het VMBO en MBO per opleidingstype, Overijssel, 2000 en 2001

\begin{tabular}{lrrl}
\hline Opleidingstype & aantal & $\begin{aligned} \text { aantal } \\
2001\end{aligned}$ & $\begin{array}{l}\text { Overijssel t.o.v. } \\
\text { Nederland 2001 }\end{array}$ \\
& 2000 & & \\
\hline MBO Dienstverlening en gezondheidszorg (vervolg) & & & \\
MBO uiterlijke verzorging & 180 & 260 & gemiddeld \\
MBO horeca & 430 & 410 & gemiddeld \\
MBO beweging en therapie & - & - & - \\
MBO Economie & & & \\
MBO administratie en logistiek & 1.310 & 1.090 & hoog \\
MBO handel & 2.260 & 1.940 & zeer hoog \\
MBO secretariaat & 290 & 300 & gemiddeld \\
MBO toerisme en recreatie & 230 & 290 & zeer hoog \\
MBO facilitaire dienstverlening & 0 & 0 & zeer laag \\
MBO ICT & 170 & 400 & zeer hoog \\
MBO geld, bank en belastingen & 70 & 130 & hoog \\
MBO verzekeringswezen & 50 & 120 & hoog \\
MBO Openbare orde en veiligheid & & & \\
MBO openbare orde en veiligheid & 40 & 20 & hoog \\
& & & \\
\hline
\end{tabular}


Tabel 2.6

Aantal gediplomeerden (BBL) in het MBO per opleidingstype, Overijssel 2000 en 2001

\begin{tabular}{|c|c|c|c|}
\hline Opleidingstype & $\begin{array}{r}\text { aantal } \\
2000\end{array}$ & $\begin{array}{r}\text { aantal } \\
2001\end{array}$ & $\begin{array}{l}\text { Overijssel t.o.v. } \\
\text { Nederland } 2001\end{array}$ \\
\hline \multicolumn{4}{|l|}{ MBO Landbouw } \\
\hline MBO voeding, natuur en milieu & 250 & 170 & - \\
\hline MBO groene ruimte & 230 & 250 & - \\
\hline \multicolumn{4}{|l|}{ MBO Techniek } \\
\hline MBO laboratorium & - & - & - \\
\hline MBO bouw & 780 & 790 & hoog \\
\hline MBO grond-, weg- en waterbouw & 160 & 150 & hoog \\
\hline MBO installatietechniek & 260 & 210 & gemiddeld \\
\hline MBO werktuigbouw en mechanische techniek & 220 & 240 & gemiddeld \\
\hline MBO fijnmechanische techniek & 0 & 0 & laag \\
\hline MBO motorvoertuigentechniek en tweewielers & 330 & 360 & gemiddeld \\
\hline MBO vliegtuigtechniek & 0 & 0 & zeer laag \\
\hline MBO operationele techniek & 40 & 70 & hoog \\
\hline MBO elektrotechniek & 200 & 280 & gemiddeld \\
\hline MBO grafische techniek & 40 & 40 & hoog \\
\hline MBO procestechniek & 10 & 10 & laag \\
\hline MBO brood en banket & 40 & 40 & gemiddeld \\
\hline MBO levensmiddelentechniek/vleesverwerking & - & - & - \\
\hline MBO vervoer & 160 & 120 & gemiddeld \\
\hline \multicolumn{4}{|l|}{ MBO Dienstverlening en gezondheidszorg } \\
\hline MBO dokters-, tandarts- en dierenartsassistent & - & - & - \\
\hline MBO apothekersassistent & - & - & - \\
\hline MBO verpleging & 0 & 120 & laag \\
\hline MBO gezondheidstechniek & 40 & 60 & gemiddeld \\
\hline MBO sociaal-pedagogisch en welzijn & 40 & 10 & zeer laag \\
\hline MBO verzorging & 320 & 390 & laag \\
\hline MBO uiterlijke verzorging & 140 & 150 & gemiddeld \\
\hline MBO horeca & 210 & 200 & laag \\
\hline MBO beweging en therapie & - & - & - \\
\hline \multicolumn{4}{|l|}{ MBO Economie } \\
\hline MBO administratie en logistiek & 70 & 140 & hoog \\
\hline MBO handel & 440 & 510 & gemiddeld \\
\hline MBO secretariaat & 20 & 40 & gemiddeld \\
\hline MBO toerisme en recreatie & 40 & 20 & zeer hoog \\
\hline MBO facilitaire dienstverlening & 0 & 0 & zeer laag \\
\hline MBO ICT & 70 & 70 & gemiddeld \\
\hline MBO geld, bank en belastingen & 0 & 0 & hoog \\
\hline MBO verzekeringswezen & - & - & - \\
\hline \multicolumn{4}{|l|}{ MBO Openbare orde en veiligheid } \\
\hline MBO openbare orde en veiligheid & - & - & - \\
\hline
\end{tabular}


Tabel 2.7

Aantal gediplomeerden (BOL) in het MBO per opleidingstype, Overijssel 2000 en 2001

\begin{tabular}{|c|c|c|c|}
\hline Opleidingstype & $\begin{array}{r}\text { aantal } \\
2000\end{array}$ & $\begin{array}{r}\text { aantal } \\
2001\end{array}$ & $\begin{array}{l}\text { Overijssel t.o.v. } \\
\text { Nederland } 2001\end{array}$ \\
\hline \multicolumn{4}{|l|}{ MBO Landbouw } \\
\hline MBO voeding, natuur en milieu & 400 & 460 & - \\
\hline MBO groene ruimte & 80 & 110 & - \\
\hline \multicolumn{4}{|l|}{ MBO Techniek } \\
\hline MBO laboratorium & 50 & 50 & laag \\
\hline MBO bouw & 340 & 300 & hoog \\
\hline MBO grond-, weg- en waterbouw & 90 & 80 & hoog \\
\hline MBO installatietechniek & 40 & 10 & laag \\
\hline MBO werktuigbouw en mechanische techniek & 180 & 160 & gemiddeld \\
\hline MBO fijnmechanische techniek en laboratorium & 20 & 30 & laag \\
\hline MBO motorvoertuigentechniek en tweewielers & 90 & 70 & gemiddeld \\
\hline MBO vliegtuigtechniek & - & - & - \\
\hline MBO operationele techniek & _ & . & - \\
\hline MBO elektrotechniek & 340 & 230 & gemiddeld \\
\hline MBO grafische techniek & 190 & 200 & zeer hoog \\
\hline MBO procestechniek & 20 & 0 & zeer laag \\
\hline MBO brood en banket & 10 & 10 & laag \\
\hline MBO levensmiddelentechniek/vleesverwerking & - & - & - \\
\hline MBO vervoer & 50 & 50 & gemiddeld \\
\hline \multicolumn{4}{|l|}{ MBO Dienstverlening en gezondheidszorg } \\
\hline MBO dokters-, tandarts- en dierenartsassistent & 110 & 90 & gemiddeld \\
\hline MBO apothekersassistent & 70 & 50 & gemiddeld \\
\hline MBO verpleging & 10 & 90 & gemiddeld \\
\hline MBO gezondheidstechniek & & & - \\
\hline MBO sociaal-pedagogisch en welzijn & 910 & 1.020 & gemiddeld \\
\hline MBO verzorging & 610 & 620 & gemiddeld \\
\hline MBO uiterlijke verzorging & 50 & 110 & gemiddeld \\
\hline MBO horeca & 220 & 210 & gemiddeld \\
\hline MBO beweging en therapie & - & - & - \\
\hline \multicolumn{4}{|l|}{ MBO Economie } \\
\hline MBO administratie en logistiek & 1.240 & 960 & gemiddeld \\
\hline MBO handel & 1.810 & 1.430 & zeer hoog \\
\hline MBO secretariaat & 270 & 260 & gemiddeld \\
\hline MBO toerisme en recreatie & 190 & 280 & hoog \\
\hline MBO facilitaire dienstverlening & - & - & - \\
\hline MBO ICT & 100 & 330 & hoog \\
\hline MBO geld, bank en belastingen & 70 & 130 & hoog \\
\hline MBO verzekeringswezen & 50 & 110 & hoog \\
\hline \multirow{2}{*}{$\begin{array}{l}\text { MBO Openbare orde en veiligheid } \\
\text { MBO openbare orde en veiligheid }\end{array}$} & & & \\
\hline & 40 & 20 & zeer hoog \\
\hline
\end{tabular}


Tabel 2.8

Percentage vrouwelijke gediplomeerden in het VMBO en MBO per opleidingstype, Overijssel, 2000 en 2001

\begin{tabular}{|c|c|c|c|}
\hline Opleidingstype & $\begin{array}{r}\% \\
2000\end{array}$ & $\begin{array}{r}\% \\
2001\end{array}$ & $\begin{array}{l}\text { typering t.o.v. } \\
\text { Nederland } 2001\end{array}$ \\
\hline \multicolumn{4}{|l|}{ VMBO Theorie } \\
\hline VMBO theorie & 51 & 51 & gemiddeld \\
\hline \multicolumn{4}{|l|}{ VMBO Landbouw en natuurlijke omgeving } \\
\hline VMBO landbouw en natuurlijke omgeving & 50 & 43 & - \\
\hline \multicolumn{4}{|l|}{ VMBO Techniek } \\
\hline VMBO bouwtechniek & 2 & 2 & gemiddeld \\
\hline VMBO installatietechniek & 0 & 1 & gemiddeld \\
\hline VMBO mechanische techniek & 5 & 1 & laag \\
\hline VMBO fijnmechanische techniek & - & - & - \\
\hline VMBO voertuigentechniek & 1 & 1 & laag \\
\hline VMBO elektrotechniek & 1 & 1 & laag \\
\hline VMBO grafische techniek & 12 & 10 & laag \\
\hline VMBO brood en banket & 23 & 25 & gemiddeld \\
\hline VMBO transport en logistiek & 2 & 2 & laag \\
\hline \multicolumn{4}{|l|}{ VMBO Economie } \\
\hline VMBO administratie, handel en mode & 54 & 55 & gemiddeld \\
\hline VMBO consumptief en levensmiddelentechniek & 34 & 34 & gemiddeld \\
\hline \multicolumn{4}{|l|}{ VMBO Zorg en welzijn } \\
\hline VMBO (uiterlijke) verzorging & 90 & 90 & hoog \\
\hline \multicolumn{4}{|l|}{ VMBO Beveiliging } \\
\hline VMBO beveiliging & 30 & 23 & gemiddeld \\
\hline \multicolumn{4}{|l|}{ HAVONWO } \\
\hline HAVO/VWO & 53 & 54 & hoog \\
\hline \multicolumn{4}{|l|}{ MBO Landbouw } \\
\hline MBO voeding, natuur en milieu & 51 & 54 & - \\
\hline MBO groene ruimte & 5 & 6 & - \\
\hline \multicolumn{4}{|l|}{ MBO Techniek } \\
\hline MBO laboratorium & 48 & 56 & laag \\
\hline MBO bouw & 6 & 7 & zeer hoog \\
\hline MBO grond-, weg- en waterbouw & 1 & 1 & gemiddeld \\
\hline MBO installatietechniek & 0 & 0 & gemiddeld \\
\hline MBO werktuigbouw en mechanische techniek & 2 & 1 & laag \\
\hline MBO fijnmechanische techniek & 7 & 11 & zeer laag \\
\hline MBO motorvoertuigentechniek en tweewielers & 0 & 1 & hoog \\
\hline MBO vliegtuigtechniek & - & - & - \\
\hline MBO operationele techniek & 6 & 6 & zeer hoog \\
\hline MBO elektrotechniek & 0 & 1 & gemiddeld \\
\hline MBO grafische techniek & 25 & 31 & hoog \\
\hline MBO procestechniek & 3 & 0 & zeer laag \\
\hline MBO brood en banket & 20 & 16 & laag \\
\hline MBO levensmiddelentechniek/vleesverwerking & - & - & - \\
\hline MBO vervoer & 5 & 9 & laag \\
\hline \multicolumn{4}{|l|}{ MBO Dienstverlening en gezondheidszorg } \\
\hline MBO dokters-, tandarts- en dierenartsassistent & 100 & 100 & gemiddeld \\
\hline MBO apothekersassistent & 99 & 100 & gemiddeld \\
\hline MBO verpleging & 33 & 90 & gemiddeld \\
\hline MBO gezondheidstechniek & 68 & 63 & hoog \\
\hline MBO sociaal-pedagogisch en welzijn & 88 & 86 & gemiddeld \\
\hline
\end{tabular}


Tabel 2.8 (vervolg)

Percentage vrouwelijke gediplomeerden in het VMBO en MBO per opleidingstype, Overijssel, 2000 en 2001

\begin{tabular}{|c|c|c|c|}
\hline Opleidingstype & $\begin{array}{r}\% \\
2000\end{array}$ & $\begin{array}{r}\% \\
2001\end{array}$ & $\begin{array}{l}\text { typering t.o.v. } \\
\text { Nederland } 2001\end{array}$ \\
\hline \multicolumn{4}{|c|}{ MBO Dienstverlening en gezondheidszorg (vervolg) } \\
\hline MBO verzorging & 91 & 94 & gemiddeld \\
\hline MBO uiterlijke verzorging & 99 & 98 & gemiddeld \\
\hline MBO horeca & 47 & 42 & gemiddeld \\
\hline MBO beweging en therapie & - & - & - \\
\hline \multicolumn{4}{|l|}{ MBO Economie } \\
\hline MBO administratie en logistiek & 26 & 34 & gemiddeld \\
\hline MBO handel & 52 & 50 & hoog \\
\hline MBO secretariaat & 100 & 99 & gemiddeld \\
\hline MBO toerisme en recreatie & 85 & 87 & hoog \\
\hline MBO facilitaire dienstverlening & - & - & - \\
\hline MBO ICT & 5 & 5 & hoog \\
\hline MBO geld, bank en belastingen & 37 & 52 & hoog \\
\hline MBO verzekeringswezen & 35 & 56 & hoog \\
\hline \multicolumn{4}{|l|}{ MBO Openbare orde en veiligheid } \\
\hline MBO openbare orde en veiligheid & 39 & 17 & gemiddeld \\
\hline
\end{tabular}


3 Actuele discrepanties op de Overijsselse arbeidsmarkt 

Tabel 3.1

Openstaande vacatures per bedrijfssector, Overijssel, april 2003

\begin{tabular}{|c|c|c|c|c|c|}
\hline Bedrijfssector & aantal & $\begin{array}{r}\text { vacature- } \\
\text { graad }\end{array}$ & typering & $\begin{array}{c}\text { langdurig } \\
\text { openstaand } \\
\%\end{array}$ & typering \\
\hline Landbouw en visserij & 75 & 5 & zeer laag & 9 & laag \\
\hline Voeding & 125 & 10 & gemiddeld & 49 & zeer hoog \\
\hline Chemie & 50 & 7 & laag & 13 & laag \\
\hline Metaal en elektrotechniek & 225 & 7 & laag & 40 & hoog \\
\hline Overige industrie & 150 & 5 & zeer laag & 27 & gemiddeld \\
\hline Energie & & - & - & - & - \\
\hline Bouw en onroerend goed & 475 & 11 & gemiddeld & 16 & laag \\
\hline Handel en reparatie & 1.100 & 16 & gemiddeld & 45 & hoog \\
\hline Horeca en zakelijke dienstverlening & 4.600 & 75 & zeer hoog & 31 & gemiddeld \\
\hline Transport en communicatie & 375 & 19 & gemiddeld & 29 & gemiddeld \\
\hline Bank- en verzekeringswezen & 325 & 27 & hoog & 7 & zeer laag \\
\hline Kwartaire diensten & 2.575 & 30 & hoog & 37 & gemiddeld \\
\hline Overheid en onderwijs & 375 & 5 & zeer laag & 47 & zeer hoog \\
\hline Totaal & 10.450 & 23 & - & 12 & - \\
\hline
\end{tabular}

Bron: CBS/CWI/Etil/ROA 
Tabel 3.2

Openstaande vacatures per beroepssegment, Overijssel, april 2003

\begin{tabular}{|c|c|c|c|c|c|}
\hline Beroepssegment & aantal & $\begin{array}{c}\text { vacature- } \\
\text { graad } \\
\% \text { o }\end{array}$ & - typering & $\begin{array}{c}\text { langdurig } \\
\text { open- } \\
\text { staand } \\
\%\end{array}$ & typering \\
\hline Elementaire beroepen & 1.100 & 36 & hoog & 9 & gemiddeld \\
\hline Lagere niet-specialistische beroepen & - & - & - & - & - \\
\hline Lagere docenten sportvakken & 25 & 69 & zeer hoog & - & - \\
\hline Lagere agrarische beroepen & 75 & 10 & laag & 3 & zeer laag \\
\hline Lagere wiskundige, natuurwetenschappelijke beroepen & - & - & - & - & - \\
\hline Lagere technische beroepen & 675 & 17 & laag & 19 & hoog \\
\hline Lagere transportberoepen & 150 & 12 & laag & 32 & hoog \\
\hline Lagere (para)medische beroepen & - & - & - & - & - \\
\hline Lagere administratieve, commerciële beroepen e.d. & 750 & 20 & gemiddeld & 7 & laag \\
\hline Lagere beveiligingsberoepen & 125 & 44 & hoog & 5 & laag \\
\hline Lagere verzorgende beroepen & 625 & 59 & hoog & 26 & hoog \\
\hline Middelbare docenten transport-, sportvakken & 75 & 78 & zeer hoog & 63 & zeer hoog \\
\hline Middelbare agrarische beroepen & 25 & 3 & zeer laag & 24 & hoog \\
\hline Middelbare wiskundige, natuurwetenschappelijke beroepen & - & - & - & - & - \\
\hline Middelbare technische beroepen & 1.200 & 22 & gemiddeld & 11 & gemiddeld \\
\hline Middelbare transportberoepen e.d. & 25 & 8 & laag & 63 & zeer hoog \\
\hline Middelbare (para)medische beroepen & 350 & 20 & laag & 10 & gemiddeld \\
\hline Middelbare administratieve, commerciële beroepen e.d. & 1.225 & 18 & laag & 10 & gemiddeld \\
\hline Middelbare juridische, bestuurlijke, beveiligingsberoepen & 25 & 5 & zeer laag & - & - \\
\hline Middelbare taalkundige, culturele beroepen & 25 & 9 & laag & 16 & gemiddeld \\
\hline Middelbare beroepen m.b.t. gedrag en maatschappij & 175 & 38 & hoog & 16 & gemiddeld \\
\hline Middelbare verzorgende beroepen e.d. & 825 & 53 & hoog & 8 & laag \\
\hline Hogere pedagogische beroepen & 475 & 27 & gemiddeld & 7 & laag \\
\hline Hogere landbouwkundige beroepen & - & - & - & - & - \\
\hline Hogere wiskundige, natuurwetenschappelijke beroepen & . & - & - & - & - \\
\hline Hogere technische beroepen & 225 & 27 & gemiddeld & 3 & zeer laag \\
\hline Hogere transportberoepen & - & - & - & - & - \\
\hline Hogere (para)medische beroepen & 250 & 23 & gemiddeld & 8 & laag \\
\hline Hogere administratieve, commerciële, economische beroepen & 775 & 25 & gemiddeld & 3 & zeer laag \\
\hline Hogere juridische, bestuurlijke, beveiligingsberoepen & 25 & 14 & laag & - & - \\
\hline Hogere taalkundige, culturele beroepen & 25 & 6 & zeer laag & - & - \\
\hline Hogere beroepen mbt gedrag en maatschappij e.d. & 325 & 36 & hoog & 4 & laag \\
\hline Hogere verzorgende beroepen & 100 & 172 & zeer hoog & - & - \\
\hline Managers (HBO werk- en denkniveau) e.d. & 25 & 7 & zeer laag & - & - \\
\hline Wetenschappelijke pedagogische beroepen & 75 & 11 & laag & - & - \\
\hline Wetenschappelijke landbouwkundige beroepen & & - & - & - & - \\
\hline Wetenschappelijke wiskundige, natuurwetenschappelijke beroepen & 25 & 22 & gemiddeld & - & - \\
\hline Wetenschappelijke technische beroepen & 75 & 23 & gemiddeld & - & - \\
\hline Wetenschappelijke (para)medische beroepen e.d. & 100 & 20 & gemiddeld & - & - \\
\hline Wetenschappelijke economische, administratieve beroepen e.d. & 75 & 11 & laag & 17 & gemiddeld \\
\hline Wetenschappelijke, juridische, bestuurlijke beroepen & 200 & 52 & hoog & 27 & hoog \\
\hline Wetenschappelijke beroepen m.b.t. gedrag en maatschappij e.d. & 125 & 33 & gemiddeld & 6 & laag \\
\hline Managers (wetenschappelijke werk- en denkniveau) & - & - & - & - & - \\
\hline Totaal & 10.450 & - & - & - & - \\
\hline
\end{tabular}

Bron: CBS/CWI/Etil/ROA 
Tabel 3.3

Niet-werkende werkzoekenden per beroepssegment, Overijssel, april 2003

\begin{tabular}{|c|c|c|c|c|c|}
\hline \multirow{2}{*}{$\begin{array}{l}\text { Beroepssegment } \\
\text { Elementaire beroepen }\end{array}$} & \multicolumn{2}{|c|}{$\begin{array}{c}\text { aantal werkloos- } \\
\text { heid } \\
\%\end{array}$} & $\begin{array}{l}\text { typering } \\
\text { beroeps- } \\
\text { bevolking } \\
\%\end{array}$ & $\begin{array}{c}\text { langdur } \\
\text { zoeken } \\
\%\end{array}$ & $\begin{array}{l}\text { g typering } \\
\text { d }\end{array}$ \\
\hline & 11.425 & 37 & zeer hoog & 50 & hoog \\
\hline Lagere niet-specialistische beroepen & 25 & 3 & laag & 12 & zeer laag \\
\hline Lagere docenten sportvakken & 0 & 0 & zeer laag & 0 & zeer laag \\
\hline Lagere agrarische beroepen & 375 & 5 & gemiddeld & 40 & laag \\
\hline Lagere wiskundige, natuurwetenschappelijke beroepen & 25 & 21 & zeer hoog & 52 & hoog \\
\hline Lagere technische beroepen & 3.025 & 8 & hoog & 37 & laag \\
\hline Lagere transportberoepen & 1.625 & 13 & zeer hoog & 46 & gemiddeld \\
\hline Lagere (para)medische beroepen & 0 & 0 & zeer laag & 0 & zeer laag \\
\hline Lagere administratieve, commerciële beroepen e.d. & 3.825 & 10 & hoog & 40 & laag \\
\hline Lagere beveiligingsberoepen & 275 & 10 & hoog & 52 & hoog \\
\hline Lagere verzorgende beroepen & 1.900 & 18 & zeer hoog & 51 & hoog \\
\hline Middelbare docenten transport-, sportvakken & 100 & 10 & hoog & 42 & gemiddeld \\
\hline Middelbare agrarische beroepen & 175 & 2 & laag & 52 & hoog \\
\hline Middelbare wiskundige, natuurwetenschappelijke beroepen & 50 & 5 & gemiddeld & 48 & gemiddeld \\
\hline Middelbare technische beroepen & 2.850 & 5 & gemiddeld & 38 & laag \\
\hline Middelbare transportberoepen e.d. & 150 & 5 & gemiddeld & 67 & zeer hoog \\
\hline Middelbare (para)medische beroepen & 350 & 2 & laag & 42 & gemiddeld \\
\hline Middelbare administratieve, commerciële beroepen e.d. & 4.550 & 7 & gemiddeld & 48 & gemiddeld \\
\hline Middelbare juridische, bestuurlijke, beveiligingsberoepen & 25 & 0 & zeer laag & 35 & laag \\
\hline Middelbare taalkundige, culturele beroepen & 150 & 5 & gemiddeld & 48 & gemiddeld \\
\hline Middelbare beroepen m.b.t. gedrag en maatschappij & 500 & 11 & hoog & 41 & gemiddeld \\
\hline Middelbare verzorgende beroepen e.d. & 1.025 & 7 & gemiddeld & 40 & laag \\
\hline Hogere pedagogische beroepen & 550 & 3 & laag & 58 & hoog \\
\hline Hogere landbouwkundige beroepen & 25 & 3 & laag & 26 & laag \\
\hline Hogere wiskundige, natuurwetenschappelijke beroepen & 25 & 4 & laag & 43 & gemiddeld \\
\hline Hogere technische beroepen & 400 & 5 & gemiddeld & 30 & laag \\
\hline Hogere transportberoepen & 25 & 3 & laag & 17 & zeer laag \\
\hline Hogere (para)medische beroepen & 100 & 1 & zeer laag & 45 & gemiddeld \\
\hline Hogere administratieve, commerciële, economische beroepen & 1.125 & 4 & laag & 36 & laag \\
\hline Hogere juridische, bestuurlijke, beveiligingsberoepen & 0 & 0 & zeer laag & 59 & hoog \\
\hline Hogere taalkundige, culturele beroepen & 400 & 10 & hoog & 61 & zeer hoog \\
\hline Hogere beroepen m.b.t. gedrag en maatschappij e.d. & 575 & 6 & gemiddeld & 45 & gemiddeld \\
\hline Hogere verzorgende beroepen & 50 & 9 & hoog & 53 & hoog \\
\hline Managers (HBO werk- en denkniveau) e.d. & 200 & 6 & gemiddeld & 63 & zeer hoog \\
\hline Wetenschappelijke pedagogische beroepen & 100 & 1 & zeer laag & 27 & laag \\
\hline Wetenschappelijke landbouwkundige beroepen & 25 & 12 & hoog & 21 & zeer laag \\
\hline happelijke wiskundige, natuurwetenschappelijke beroepen & 50 & 4 & laag & 44 & gemiddeld \\
\hline Wetenschappelijke technische beroepen & 175 & 5 & gemiddeld & 38 & laag \\
\hline Wetenschappelijke (para)medische beroepen e.d. & 75 & 1 & zeer laag & 38 & laag \\
\hline Wetenschappelijke economische, administratieve beroepen e.d. & 175 & 3 & laag & 39 & Laag \\
\hline Wetenschappelijke, juridische, bestuurlijke beroepen & 75 & 2 & laag & 25 & laag \\
\hline Wetenschappelijke beroepen mbt gedrag en maatschappij e.d. & 50 & 1 & zeer laag & 31 & laag \\
\hline Managers (wetenschappelijke werk- en denkniveau) & 100 & 1 & zeer laag & 85 & zeer hoog \\
\hline Totaal & 36.725 & - & - & 45 & - \\
\hline
\end{tabular}

Bron: CBS/CWI/Etil/ROA 
Tabel 3.4

Niet-werkende werkzoekenden per beroepssegment en bemiddelingsfase, Overijssel, april 2003

\begin{tabular}{|c|c|c|c|c|}
\hline Beroepssegment & $\begin{array}{r}\text { fase } 1 \\
\%\end{array}$ & typering & $\begin{array}{c}\text { fase } 2+3 \\
\%\end{array}$ & typering \\
\hline Elementaire beroepen & 18 & laag & 26 & laag \\
\hline Lagere niet-specialistische beroepen & 44 & zeer hoog & 21 & zeer laag \\
\hline Lagere docenten sportvakken & 49 & zeer hoog & 18 & zeer laag \\
\hline Lagere agrarische beroepen & 22 & laag & 22 & zeer laag \\
\hline Lagere wiskundige, natuurwetenschappelijke beroepen & 13 & laag & 38 & gemiddeld \\
\hline Lagere technische beroepen & 33 & hoog & 27 & laag \\
\hline Lagere transportberoepen & 24 & gemiddeld & 34 & gemiddeld \\
\hline Lagere (para)medische beroepen & 0 & zeer laag & 37 & gemiddeld \\
\hline Lagere administratieve, commerciële beroepen e.d. & 28 & gemiddeld & 37 & gemiddeld \\
\hline Lagere beveiligingsberoepen & 24 & laag & 32 & laag \\
\hline Lagere verzorgende beroepen & 13 & zeer laag & 29 & laag \\
\hline Middelbare docenten transport-, sportvakken & 17 & laag & 43 & hoog \\
\hline Middelbare agrarische beroepen & 19 & laag & 29 & laag \\
\hline Middelbare wiskundige, natuurwetenschappelijke beroepen & 24 & laag & 30 & laag \\
\hline Middelbare technische beroepen & 33 & hoog & 26 & laag \\
\hline Middelbare transportberoepen e.d. & 13 & zeer laag & 23 & laag \\
\hline Middelbare (para)medische beroepen & 20 & laag & 41 & hoog \\
\hline Middelbare administratieve, commerciële beroepen e.d. & 29 & gemiddeld & 37 & gemiddeld \\
\hline Middelbare juridische, bestuurlijke, beveiligingsberoepen & 22 & gemiddeld & 19 & zeer laag \\
\hline Middelbare taalkundige, culturele beroepen & 27 & gemiddeld & 45 & zeer hoog \\
\hline Middelbare beroepen m.b.t. gedrag en maatschappij & 27 & gemiddeld & 42 & hoog \\
\hline Middelbare verzorgende beroepen e.d. & 17 & laag & 39 & hoog \\
\hline Hogere pedagogische beroepen & 18 & laag & 32 & laag \\
\hline Hogere landbouwkundige beroepen & 62 & zeer hoog & 28 & laag \\
\hline Hogere wiskundige, natuurwetenschappelijke beroepen & 27 & gemiddeld & 43 & hoog \\
\hline Hogere technische beroepen & 40 & hoog & 34 & gemiddeld \\
\hline Hogere transportberoepen & 35 & hoog & 8 & zeer laag \\
\hline Hogere (para)medische beroepen & 21 & laag & 55 & zeer hoog \\
\hline Hogere administratieve, commerciële, economische beroepen & 39 & hoog & 34 & gemiddeld \\
\hline Hogere juridische, bestuurlijke, beveiligingsberoepen & 28 & gemiddeld & 54 & zeer hoog \\
\hline Hogere taalkundige, culturele beroepen & 14 & laag & 24 & laag \\
\hline Hogere beroepen mbt gedrag en maatschappij e.d. & 29 & gemiddeld & 40 & hoog \\
\hline Hogere verzorgende beroepen & 29 & gemiddeld & 36 & gemiddeld \\
\hline Managers (HBO werk- en denkniveau) e.d. & 21 & laag & 38 & gemiddeld \\
\hline Wetenschappelijke pedagogische beroepen & 34 & hoog & 43 & hoog \\
\hline Wetenschappelijke landbouwkundige beroepen & 45 & zeer hoog & 37 & gemiddeld \\
\hline Wetenschappelijke wiskundige, natuurwetenschappelijke beroepen & 30 & gemiddeld & 29 & laag \\
\hline Wetenschappelijke technische beroepen & 40 & zeer hoog & 32 & laag \\
\hline Wetenschappelijke (para)medische beroepen e.d. & 29 & gemiddeld & 25 & laag \\
\hline Wetenschappelijke economische, administratieve beroepen e.d. & 38 & hoog & 35 & gemiddeld \\
\hline Wetenschappelijke, juridische, bestuurlijke beroepen & 35 & hoog & 33 & gemiddeld \\
\hline Wetenschappelijke beroepen m.b.t. gedrag en maatschappij e.d. & 33 & hoog & 40 & hoog \\
\hline Managers (wetenschappelijke werk- en denkniveau) & 7 & zeer laag & 23 & laag \\
\hline Totaal & 24 & - & 31 & - \\
\hline
\end{tabular}

Bron: CBS/CWI/Etil/ROA 
Tabel 3.5

Kenmerken niet-werkende werkzoekenden per beroepssegment, Overijssel, april 2003

\begin{tabular}{|c|c|c|c|}
\hline Beroepssegment & $\begin{array}{r}\text { vrouw } \\
\%\end{array}$ & $\begin{array}{r}\text { jong } \\
(15-29) \\
\%\end{array}$ & $\begin{array}{r}\text { oud } \\
(50-64) \\
\%\end{array}$ \\
\hline Elementaire beroepen & 49 & 29 & 21 \\
\hline Lagere niet-specialistische beroepen & 40 & 45 & 16 \\
\hline Lagere docenten sportvakken & 100 & 38 & 20 \\
\hline Lagere agrarische beroepen & 21 & 30 & 24 \\
\hline Lagere wiskundige, natuurwetenschappelijke beroepen & 48 & 21 & 11 \\
\hline Lagere technische beroepen & 9 & 26 & 28 \\
\hline Lagere transportberoepen & 11 & 17 & 31 \\
\hline Lagere (para)medische beroepen & 100 & 0 & 51 \\
\hline Lagere administratieve, commerciële beroepen e.d. & 91 & 33 & 19 \\
\hline Lagere beveiligingsberoepen & 24 & 41 & 18 \\
\hline Lagere verzorgende beroepen & 91 & 30 & 22 \\
\hline Middelbare docenten transport-, sportvakken & 35 & 19 & 30 \\
\hline Middelbare agrarische beroepen & 24 & 19 & 34 \\
\hline Middelbare wiskundige, natuurwetenschappelijke beroepen & 50 & 39 & 32 \\
\hline Middelbare technische beroepen & 15 & 21 & 29 \\
\hline Middelbare transportberoepen e.d. & 7 & 14 & 43 \\
\hline Middelbare (para)medische beroepen & 95 & 20 & 23 \\
\hline Middelbare administratieve, commerciële beroepen e.d. & 57 & 23 & 26 \\
\hline Middelbare juridische, bestuurlijke, beveiligingsberoepen & 43 & 48 & 10 \\
\hline Middelbare taalkundige, culturele beroepen & 48 & 23 & 23 \\
\hline Middelbare beroepen m.b.t. gedrag en maatschappij & 73 & 27 & 17 \\
\hline Middelbare verzorgende beroepen e.d. & 77 & 29 & 20 \\
\hline Hogere pedagogische beroepen & 62 & 9 & 40 \\
\hline Hogere landbouwkundige beroepen & 18 & 21 & 23 \\
\hline Hogere wiskundige, natuurwetenschappelijke beroepen & 56 & 30 & 11 \\
\hline Hogere technische beroepen & 10 & 17 & 34 \\
\hline Hogere transportberoepen & 15 & 14 & 15 \\
\hline Hogere (para)medische beroepen & 92 & 21 & 22 \\
\hline Hogere administratieve, commerciële, economische beroepen & 19 & 12 & 33 \\
\hline Hogere juridische, bestuurlijke, beveiligingsberoepen & 0 & 24 & 51 \\
\hline Hogere taalkundige, culturele beroepen & 50 & 16 & 32 \\
\hline Hogere beroepen mbt gedrag en maatschappij e.d. & 64 & 20 & 27 \\
\hline Hogere verzorgende beroepen & 52 & 9 & 49 \\
\hline Managers (HBO werk- en denkniveau) e.d. & 16 & 4 & 52 \\
\hline Wetenschappelijke pedagogische beroepen & 56 & 19 & 31 \\
\hline Wetenschappelijke landbouwkundige beroepen & 29 & 39 & 14 \\
\hline Wetenschappelijke wiskundige, natuurwetenschappelijke beroepen & 44 & 28 & 23 \\
\hline Wetenschappelijke technische beroepen & 8 & 23 & 31 \\
\hline Wetenschappelijke (para)medische beroepen e.d. & 43 & 10 & 30 \\
\hline Wetenschappelijke economische, administratieve beroepen e.d. & 12 & 7 & 37 \\
\hline Wetenschappelijke, juridische, bestuurlijke beroepen & 39 & 26 & 27 \\
\hline Wetenschappelijke beroepen m.b.t. gedrag en maatschappij e.d. & 57 & 30 & 32 \\
\hline Managers (wetenschappelijke werk- en denkniveau) & 12 & 2 & 80 \\
\hline Totaal & 48 & 25 & 25 \\
\hline
\end{tabular}

Bron: CBS/CWI/Etil/ROA 
Tabel 3.6

Discrepanties per bedrijfssector, Overijssel, april 2003

\begin{tabular}{|c|c|c|c|}
\hline Bedrijfssector & arbeidsmarktkrapte & typering & knelpuntindicator \\
\hline Landbouw en visserij & 0,28 & zeer laag & 0,00 \\
\hline Voeding & 1,30 & hoog & 0,27 \\
\hline Chemie & 0,35 & laag & 0,00 \\
\hline Metaal en elektrotechniek & 0,47 & laag & 0,00 \\
\hline Overige industrie & 0,63 & gemiddeld & 0,00 \\
\hline Energie & - & - & - \\
\hline Bouw en onroerend goed & 0,53 & laag & 0,00 \\
\hline Handel en reparatie & 0,62 & gemiddeld & 0,00 \\
\hline Horeca en zakelijke dienstverlening & 6,76 & zeer hoog & 4,46 \\
\hline Transport en communicatie & 0,55 & gemiddeld & 0,00 \\
\hline Bank- en verzekeringswezen & 0,32 & zeer laag & 0,00 \\
\hline Kwartaire diensten & 3,29 & hoog & 1,82 \\
\hline Overheid en onderwijs & 0,57 & gemiddeld & 0,00 \\
\hline Totaal & 1,17 & - & 0,13 \\
\hline
\end{tabular}

Bron: $\mathrm{CBS} / \mathrm{CWI} / \mathrm{Etil} / \mathrm{ROA}$ 
Tabel 3.7

Discrepanties per beroepssegment, Overijssel, april 2003

\begin{tabular}{|c|c|c|c|}
\hline Beroepssegment & $\begin{array}{l}\text { arbeidsmarkt- } \\
\text { krapte }\end{array}$ & typering & $\begin{array}{c}\text { knelpunt- } \\
\text { indicator } \\
\%\end{array}$ \\
\hline Elementaire beroepen & 0,54 & zeer laag & 0,00 \\
\hline Lagere niet-specialistische beroepen & - & - & _ \\
\hline Lagere docenten sportvakken & - & - & - \\
\hline Lagere agrarische beroepen & 0,93 & laag & 0,00 \\
\hline Lagere wiskundige, natuurwetenschappelijke beroepen & - & - & - \\
\hline Lagere technische beroepen & 0,67 & laag & 0,00 \\
\hline Lagere transportberoepen & 0,39 & zeer laag & 0,00 \\
\hline Lagere (para)medische beroepen & - & - & - \\
\hline Lagere administratieve, commerciële beroepen e.d. & 0,70 & laag & 0,00 \\
\hline Lagere beveiligingsberoepen & 1,93 & gemiddeld & 0,69 \\
\hline Lagere verzorgende beroepen & 2,44 & gemiddeld & 0,67 \\
\hline Middelbare docenten transport-, sportvakken & 4,32 & gemiddeld & 1,33 \\
\hline Middelbare agrarische beroepen & 0,74 & laag & 0,00 \\
\hline Middelbare wiskundige, natuurwetenschappelijke beroepen & - & - & - \\
\hline Middelbare technische beroepen & 1,27 & laag & 0,34 \\
\hline Middelbare transportberoepen e.d. & 1,31 & laag & 0,17 \\
\hline Middelbare (para)medische beroepen & 5,10 & hoog & 1,97 \\
\hline Middelbare administratieve, commerciële beroepen e.d. & 0,94 & laag & 0,00 \\
\hline Middelbare juridische, bestuurlijke, beveiligingsberoepen & 4,53 & hoog & 4,10 \\
\hline Middelbare taalkundige, culturele beroepen & 0,62 & zeer laag & 0,00 \\
\hline Middelbare beroepen m.b.t. gedrag en maatschappij & 1,32 & gemiddeld & 0,20 \\
\hline Middelbare verzorgende beroepen e.d. & 4,76 & hoog & 1,61 \\
\hline Hogere pedagogische beroepen & 4,91 & hoog & 2,15 \\
\hline Hogere landbouwkundige beroepen & - & - & - \\
\hline Hogere wiskundige, natuurwetenschappelijke beroepen & - & - & - \\
\hline Hogere technische beroepen & 1,40 & gemiddeld & 0,47 \\
\hline Hogere transportberoepen & - & - & - \\
\hline Hogere (para)medische beroepen & 12,06 & zeer hoog & 4,14 \\
\hline Hogere administratieve, commerciële, economische beroepen & 1,74 & gemiddeld & 0,86 \\
\hline Hogere juridische, bestuurlijke, beveiligingsberoepen & - & - & - \\
\hline Hogere taalkundige, culturele beroepen & - & - & - \\
\hline Hogere beroepen mbt gedrag en maatschappij e.d. & 1,98 & gemiddeld & 0,71 \\
\hline Hogere verzorgende beroepen & 6,98 & hoog & 4,73 \\
\hline Managers (HBO werk- en denkniveau) e.d. & 0,60 & zeer laag & 0,00 \\
\hline Wetenschappelijke pedagogische beroepen & 2,18 & gemiddeld & 0,95 \\
\hline Wetenschappelijke landbouwkundige beroepen & - & - & - \\
\hline Wetenschappelijke wiskundige, natuurwetenschappelijke beroepen & 1,69 & gemiddeld & 0,70 \\
\hline Wetenschappelijke technische beroepen & 1,06 & laag & 0,08 \\
\hline Wetenschappelijke (para)medische beroepen e.d. & 4,58 & hoog & 4,14 \\
\hline Wetenschappelijke economische, administratieve beroepen e.d. & 1,12 & laag & 0,14 \\
\hline Wetenschappelijke, juridische, bestuurlijke beroepen & 7,59 & zeer hoog & 7,01 \\
\hline Wetenschappelijke beroepen m.b.t. gedrag en maatschappij e.d. & 7,46 & zeer hoog & 5,46 \\
\hline Managers (wetenschappelijke werk- en denkniveau) & - & - & - \\
\hline Totaal & 1,17 & - & 0,13 \\
\hline
\end{tabular}

Bron: CBS/CWI/Etil/ROA 
Tabel 3.8

Werkloosheid (in procenten) onder MBO-schoolverlaters per opleidingssector, Overijssel en Nederland, 2002

Opleidingssector

Overijssel

Nederland

MBO Techniek

MBO Dienstverlening en gezondheidszorg

MBO Economie

MBO Openbare orde- en veiligheid

2

MBO Totaal

2

Bron: ROA 
Tabel 3.9

Intredewerkloosheid (langer dan 4 maanden, in procenten) onder MBO-schoolverlaters per opleidingssector, Overijssel en Nederland, 2002

\begin{tabular}{lcc} 
Opleidingssector & Overijssel & Nederland \\
\hline MBO Landbouw & 6 & 2 \\
MBO Techniek & 3 & 2 \\
MBO Dienstverlening en gezondheidszorg & 3 & 2 \\
MBO Economie & 4 & 4 \\
MBO Openbare orde- en veiligheid & - & - \\
MBO Totaal & 3 & 3
\end{tabular}

Bron: ROA 
Tabel 3.10

Gemiddeld bruto maandloon (in euro's) onder MBO-schoolverlaters per opleidingssector, Overijssel en Nederland, 2002

\begin{tabular}{lcc}
\hline Opleidingssector & Overijssel & Nederland \\
\hline MBO Landbouw & 1.200 & 1.250 \\
MBO Techniek & 1.450 & 1.550 \\
MBO Dienstverlening en gezondheidszorg & 1.550 & 1.500 \\
MBO Economie & 1.200 & 1.250 \\
MBO Openbare orde- en veiligheid & 1.100 & 1.100 \\
MBO Totaal & 1.300 & 1.350
\end{tabular}

Bron: ROA 
Tabel 3.11

Percentage MBO-schoolverlaters met een flexibele aanstelling per opleidingssector, Overijssel en Nederland, 2002

\begin{tabular}{lcc} 
Opleidingssector & Overijssel & Nederland \\
\hline MBO Landbouw & 20 & 19 \\
MBO Techniek & 10 & 11 \\
MBO Dienstverlening en gezondheidszorg & 13 & 14 \\
MBO Economie & 21 & 22 \\
MBO Openbare orde- en veiligheid & 40 & 40 \\
MBO Totaal & 13 & 15
\end{tabular}

Bron: ROA 
Tabel 3.12

Percentage MBO-schoolverlaters dat in deeltijd (12 tot 32 uur per week) werkt per opleidingssector, Overijssel en Nederland, 2002

\begin{tabular}{lrr} 
Opleidingssector & Overijssel & Nederland \\
\hline MBO Landbouw & 24 & 25 \\
MBO Techniek & 6 & 8 \\
MBO Dienstverlening en gezondheidszorg & 51 & 55 \\
MBO Economie & 30 & 24 \\
MBO Openbare orde- en veiligheid & 20 & 20 \\
MBO Totaal & 26 & 31
\end{tabular}

Bron: ROA 
Tabel 3.13

Onderbenutting van MBO-schoolverlaters per opleidingssector, Overijssel en Nederland, 2002

Opleidingssector

Overijssel

Nederland

MBO Landbouw

65

57

MBO Techniek

$43-40$

MBO Dienstverlening en gezondheidszorg

MBO Economie

MBO Openbare orde- en veiligheid

13

44

50

20

MBO Totaal

33

33

Bron: ROA 
Tabel 3.14

Percentage MBO-schoolverlaters dat buiten de eigen vakrichting werkzaam is, per opleidingssector, Overijssel en Nederland, 2002

\begin{tabular}{lcc} 
Opleidingssector & Overijssel & Nederland \\
\hline MBO Landbouw & 29 & 37 \\
MBO Techniek & 23 & 21 \\
MBO Dienstverlening en gezondheidszorg & 18 & 20 \\
MBO Economie & 43 & 38 \\
MBO Openbare orde- en veiligheid & 50 & 50 \\
MBO Totaal & 26 & 26
\end{tabular}

Bron: ROA 
4 De Overijsselse arbeidsmarkt in 2004 

Tabel 4.1

Verwachte uitbreidingsvraag per bedrijfssector (als percentage van de werkgelegenheid), Overijssel, 2004

\begin{tabular}{lcl}
\hline Bedrijfssector & $\%$ & typering \\
\hline Landbouw en visserij & $-1,6$ & laag \\
Voeding & $-1,6$ & laag \\
Chemie & $-1,1$ & gemiddeld \\
Metaal en elektrotechniek & $-1,7$ & laag \\
Overige industrie & $-1,8$ & erg laag \\
Energie & $-0,4$ & gemiddeld \\
Bouw en onroerend goed & $-0,7$ & gemiddeld \\
Handel & 0 & gemiddeld \\
Transport en communicatie & 0 & gemiddeld \\
Bank en verzekeringswezen & 0,6 & hoog \\
Horeca, reparatie en zak. diensten & 0,5 & hoog \\
Kwartaire diensten & 0,5 & hoog \\
Overheid en onderwijs & 0,6 & erg hoog \\
Totaal & $-0,2$ & -
\end{tabular}

Bron: ROA 
Tabel 4.2

Verwachte uitbreidingsvraag per beroepsgroep (als percentage van de werkgelegenheid), Overijssel, 2004

\begin{tabular}{|c|c|c|}
\hline Beroepsgroep & $\%$ & typering \\
\hline Leraar basisonderwijs & $-4,5$ & erg laag \\
\hline Docenten exacte, med. en verz. vakken $(2 \mathrm{e}+3 \mathrm{e}$ gr. $)$ & - & gemiddeld \\
\hline Docenten exacte, med. en verz. vakken (1e gr.) & - & erg hoog \\
\hline Docenten landbouw en techniek (2e en 3e gr.) & - & hoog \\
\hline Docenten landbouw en techniek (1e gr. en WO) & - & erg hoog \\
\hline Docenten economisch-admin. vakken (2e en 3e gr.) & - & erg hoog \\
\hline Docenten economisch-admin. vakken (1e gr.) & - & erg laag \\
\hline Docenten talen en expressie & $-2,3$ & gemiddeld \\
\hline Docenten letteren (1e gr. en WO) & 3,7 & hoog \\
\hline Docenten sociale vakken ( $2 \mathrm{e}$ en $3 \mathrm{e}$ gr.) & - & erg hoog \\
\hline Docenten sociale vakken (1e gr.) & - & gemiddeld \\
\hline Docenten $2 e$ en $3 e$ graads zonder specialisatie & - & gemiddeld \\
\hline Docent 1 e graads zonder specialisatie & - & hoog \\
\hline Onderwijskundig medewerkers & - & gemiddeld \\
\hline Onderwijskundigen en pedagogen & - & hoog \\
\hline Rij-instructeurs & - & gemiddeld \\
\hline Zweminstructeurs & - & erg laag \\
\hline Sportinstructeurs & - & erg laag \\
\hline Tolken, vertalers en schrijvers & - & erg hoog \\
\hline Bibliotheekassistenten & - & erg laag \\
\hline Bibliothecarissen & - & erg hoog \\
\hline Grafisch ontwerpers & - & hoog \\
\hline Kunstenaars & $-8,2$ & erg laag \\
\hline Geestelijk verzorgers & - & erg hoog \\
\hline Geestelijken & - & erg laag \\
\hline Journalisten & - & erg hoog \\
\hline Taalkundigen & - & erg hoog \\
\hline Agrarische hulparbeiders & - & gemiddeld \\
\hline Agrarische arbeiders & - & gemiddeld \\
\hline Agrarische vakkrachten & - & gemiddeld \\
\hline Milieuhygiënisten en agrarisch vertegenwoordigers & - & gemiddeld \\
\hline Landbouwkundigen & - & erg laag \\
\hline Landbouwmachinebestuurders en vissers & - & erg laag \\
\hline Agrarische bedrijfshoofden & -1 & gemiddeld \\
\hline Productiemedewerkers & 0,5 & gemiddeld \\
\hline Laboratoriumassistenten & - & erg laag \\
\hline Laboranten & - & gemiddeld \\
\hline Technisch analisten & - & erg hoog \\
\hline Natuurwetenschappers & - & hoog \\
\hline Conciërges & $-0,7$ & gemiddeld \\
\hline Hoofden technische dienst & - & hoog \\
\hline Werktuigbouwkundigen & - & erg hoog \\
\hline Bouwvakkers & -5 & erg laag \\
\hline Aannemers en installateurs & 4,2 & hoog \\
\hline Architecten en bouwkundig projectleiders & $-2,5$ & gemiddeld \\
\hline Weg- en waterbouwkundigen & - & erg laag \\
\hline Weg- en waterbouwkundige arbeiders & - & erg laag \\
\hline Weg- en waterbouwkundige vakkrachten & 7,5 & hoog \\
\hline Weg- en waterbouwkundig ontwerpers en projectleiders & - & erg laag \\
\hline Metaalarbeiders & $-0,4$ & gemiddeld \\
\hline Bankwerkers en lassers & 2,3 & gemiddeld \\
\hline Bedrijfshoofden metaalbewerking & - & gemiddeld \\
\hline Assembleurs & - & gemiddeld \\
\hline Monteurs & $-8,8$ & erg laag \\
\hline Werktuigbouwk. ontwerpers en hoofden techn. dienst & $-4,7$ & erg laag \\
\hline Elektronicamonteurs & - & hoog \\
\hline Monteurs en controleurs elektrotechn. producten & - & erg laag \\
\hline Elektromonteurs & 6,6 & hoog \\
\hline Electrotechnisch ontwerpers en bedrijfshoofden & - & erg laag \\
\hline Elektrotechnici & - & erg laag \\
\hline
\end{tabular}


Tabel 4.2 (vervolg)

Verwachte uitbreidingsvraag per beroepsgroep (als percentage van de werkgelegenheid), Overijssel, 2004

$\begin{array}{lll}\text { Beroepsgroep } & \% & \text { typering }\end{array}$

Grafisch productiepersoneel

erg laag

Grafische vakkrachten

3 hoog

Mechanisch operators

Procesoperators

Procestechnologen

Materiaalkundigen

Confectie-arbeiders

Schoen- en kleermakers

Laders en lossers

$\begin{array}{ll}1,3 & \text { gemiddeld } \\ 2,9 & \text { gemiddeld }\end{array}$

Chauffeurs

Schippers en conducteurs

Vliegers, scheepskapiteins en leidinggevenden transport

Stewards

Verpleeghulpen en leerling-verpleegkundigen

Verplegenden en doktersassistenten

Therapeuten en verpleegkundigen

Artsen

Apothekersassistenten en medisch laboranten

Medisch analisten

Apothekers

Afdelingshoofden zorginstelling

Kantoorhulpen, inpakkers en colporteurs

Ondersteunende administratieve hulpkrachten

Bedrijfshoofden

Economen

Productieplanners

hoog

- $\quad$ erg hoog

7,6 hoog

Organisatie-adviseurs

Organisatiedeskundigen

Receptionisten en administratieve employés

Boekhouders en secretaresses

Assistent accountants

Accountants

Verzekeringsagenten

Commercieel employés

Commercieel medewerkers

Technisch-commercieel employés

Technisch-bedrijfskundig medewerkers

Juridisch en fiscaal medewerkers

Juridisch, bestuurlijk medewerkers

Juristen

Administratieve transportemployés

erg laa

$-2 \quad$ gemiddeld

$-0,1 \quad$ gemiddeld

- $\quad$ gemiddeld

- $\quad$ hoog

hoog

erg laag

gemiddeld

gemiddeld

gemiddeld

gemiddeld

gemiddeld

gemiddeld

hoog

5 gemiddeld

erg laag

gemiddeld

gemiddeld

hoog

hoog

gemiddeld

erg laag

gemiddeld

gemiddeld

gemiddeld

gemiddeld

gemiddeld

hoog

hoog

hoog

erg hoog

- $\quad$ gemiddeld

$1,8 \quad$ gemiddeld

Leidinggevenden

gemiddeld

Managers

Medisch secretaresses

Programmeurs

Systeemanalisten

Informatici

Technisch systeemanalisten

Act.begeleiders en medew. arbeidsbemiddeling

hoog

hoog

gemiddeld

gemiddeld

hoog

gemiddeld

erg hoog

Sociaal-cultureel werkers

Sociale raadslieden en hoofden personeelszaken

gemiddeld

Sociaal-wetenschappelijk medewerkers

Sociaal-wetenschappelijk onderzoekers

Vakkenvullers

Interieurverzorgers

Verkopers

hoog

gemiddeld

erg laag

gemiddeld

gemiddeld

gemiddeld

gemiddeld

hoog

Hulpkrachten horeca en verzorging

Ziekenverzorgenden

Verzorgend personeel

hoog

gemiddeld 
Tabel 4.2 (vervolg)

Verwachte uitbreidingsvraag per beroepsgroep (als percentage van de werkgelegenheid), Overijssel, 2004

Café- en snackbarhouders

Bedrijfshoofden horeca

Bakkers en slagers

Asp. politie-agenten, soldaten en beveiligingshulpen

Agenten, onderofficieren en beveiligingsemployés

Politie-inspecteurs en officieren

Brandweerlieden

(1)

Totaal

- $\quad$ gemiddeld

- $\quad$ gemiddeld

- $\quad$ erg laag

$-5,4 \quad$ erg laag

$-6,4$ erg laag

- $\quad$ erg laag

erg laag

Bron: ROA 
Tabel 4.3

Verwachte vervangingsvraag per beroepsgroep (als percentage van de werkgelegenheid), Overijssel, 2004

\begin{tabular}{|c|c|c|}
\hline Beroepsgroep & $\%$ & typering \\
\hline Leraar basisonderwijs & 4,9 & hoog \\
\hline Docenten exacte, med. en verz. vakken $(2 \mathrm{e}+3 \mathrm{e}$ gr. $)$ & - & hoog \\
\hline Docenten exacte, med. en verz. vakken (1e gr.) & - & gemiddeld \\
\hline Docenten landbouw en techniek ( $2 \mathrm{e}$ en $3 \mathrm{e}$ gr.) & - & erg hoog \\
\hline Docenten landbouw en techniek (1e gr. en WO) & - & erg hoog \\
\hline Docenten economisch-admin. vakken (2e en 3e gr.) & - & erg hoog \\
\hline Docenten economisch-admin. vakken (1e gr.) & - & laag \\
\hline Docenten talen en expressie & 5,1 & hoog \\
\hline Docenten letteren (1e gr. en WO) & 3,2 & gemiddeld \\
\hline Docenten sociale vakken (2e en 3 e gr.) & - & hoog \\
\hline Docenten sociale vakken (1e gr.) & - & gemiddeld \\
\hline Docenten $2 \mathrm{e}$ en $3 \mathrm{e}$ graads zonder specialisatie & - & gemiddeld \\
\hline Docent $1 \mathrm{e}$ graads zonder specialisatie & - & gemiddeld \\
\hline Onderwijskundig medewerkers & - & gemiddeld \\
\hline Onderwijskundigen en pedagogen & - & laag \\
\hline Rij-instructeurs & - & gemiddeld \\
\hline Zweminstructeurs & - & erg laag \\
\hline Sportinstructeurs & - & hoog \\
\hline Tolken, vertalers en schrijvers & - & gemiddeld \\
\hline Bibliotheekassistenten & - & gemiddeld \\
\hline Bibliothecarissen & - & hoog \\
\hline Grafisch ontwerpers & - & gemiddeld \\
\hline Kunstenaars & 3,1 & gemiddeld \\
\hline Geestelijk verzorgers & - & erg hoog \\
\hline Geestelijken & - & gemiddeld \\
\hline Journalisten & - & laag \\
\hline Taalkundigen & - & erg laag \\
\hline Agrarische hulparbeiders & - & gemiddeld \\
\hline Agrarische arbeiders & 3,5 & gemiddeld \\
\hline Agrarische vakkrachten & - & gemiddeld \\
\hline Milieuhygiënisten en agrarisch vertegenwoordigers & - & hoog \\
\hline Landbouwkundigen & - & laag \\
\hline Landbouwmachinebestuurders en vissers & - & gemiddeld \\
\hline Agrarische bedrijfshoofden & 8,8 & erg hoog \\
\hline Productiemedewerkers & 3,1 & gemiddeld \\
\hline Laboratoriumassistenten & - & erg hoog \\
\hline Laboranten & - & erg laag \\
\hline Technisch analisten & - & gemiddeld \\
\hline Natuurwetenschappers & - & erg laag \\
\hline Conciërges & 6 & erg hoog \\
\hline Hoofden technische dienst & - & hoog \\
\hline Werktuigbouwkundigen & - & gemiddeld \\
\hline Bouwvakkers & 4,7 & hoog \\
\hline Aannemers en installateurs & 4 & hoog \\
\hline Architecten en bouwkundig projectleiders & 3 & gemiddeld \\
\hline Weg- en waterbouwkundigen & - & gemiddeld \\
\hline Weg- en waterbouwkundige arbeiders & - & hoog \\
\hline Weg- en waterbouwkundige vakkrachten & 6,1 & erg hoog \\
\hline Weg- en waterbouwkundig ontwerpers en projectleiders & - & hoog \\
\hline Metaalarbeiders & 4,4 & hoog \\
\hline Bankwerkers en lassers & 3,8 & gemiddeld \\
\hline Bedrijfshoofden metaalbewerking & - & gemiddeld \\
\hline Assembleurs & _ & hoog \\
\hline Monteurs & 3,7 & gemiddeld \\
\hline Werktuigbouwk. ontwerpers en hoofden techn. dienst & 4 & gemiddeld \\
\hline Elektronicamonteurs & - & gemiddeld \\
\hline Monteurs en controleurs elektrotechn. producten & - & hoog \\
\hline Elektromonteurs & 3 & gemiddeld \\
\hline Electrotechnisch ontwerpers en bedrijfshoofden & - & gemiddeld \\
\hline Elektrotechnici & - & erg laag \\
\hline
\end{tabular}


Tabel 4.3 (vervolg)

Verwachte vervangingsvraag per beroepsgroep (als percentage van de werkgelegenheid), Overijssel, 2004

\begin{tabular}{|c|c|c|}
\hline Beroepsgroep & $\%$ & typering \\
\hline Grafisch productiepersoneel & - & erg hoog \\
\hline Grafische vakkrachten & 3,8 & gemiddeld \\
\hline Mechanisch operators & 5,6 & hoog \\
\hline Procesoperators & 2,7 & gemiddeld \\
\hline Procestechnologen & - & hoog \\
\hline Materiaalkundigen & - & hoog \\
\hline Confectie-arbeiders & 3,6 & gemiddeld \\
\hline Schoen- en kleermakers & - & hoog \\
\hline Laders en lossers & 3,3 & gemiddeld \\
\hline Chauffeurs & 4,3 & hoog \\
\hline Schippers en conducteurs & - & gemiddeld \\
\hline Vliegers, scheepskapiteins en leidinggevenden transport & - & laag \\
\hline Stewards & - & erg laag \\
\hline Verpleeghulpen en leerling-verpleegkundigen & - & laag \\
\hline Verplegenden en doktersassistenten & 2,1 & laag \\
\hline Therapeuten en verpleegkundigen & 2,1 & laag \\
\hline Artsen & 2,5 & gemiddeld \\
\hline Apothekersassistenten en medisch laboranten & 1,5 & laag \\
\hline Medisch analisten & - & laag \\
\hline Apothekers & - & laag \\
\hline Afdelingshoofden zorginstelling & - & erg laag \\
\hline Kantoorhulpen, inpakkers en colporteurs & 3,9 & gemiddeld \\
\hline Ondersteunende administratieve hulpkrachten & - & laag \\
\hline Bedrijfshoofden & 3,8 & gemiddeld \\
\hline Economen & - & erg laag \\
\hline Productieplanners & 1,7 & laag \\
\hline Organisatie-adviseurs & 1,5 & laag \\
\hline Organisatiedeskundigen & - & laag \\
\hline Receptionisten en administratieve employés & 2,5 & gemiddeld \\
\hline Boekhouders en secretaresses & 2,3 & laag \\
\hline Assistent accountants & 1,1 & erg laag \\
\hline Accountants & 2 & laag \\
\hline Verzekeringsagenten & 2 & laag \\
\hline Commercieel employés & 1,9 & laag \\
\hline Commercieel medewerkers & 2 & laag \\
\hline Technisch-commercieel employés & - & hoog \\
\hline Technisch-bedrijfskundig medewerkers & - & laag \\
\hline Juridisch en fiscaal medewerkers & 6 & erg hoog \\
\hline Juridisch, bestuurlijk medewerkers & - & gemiddeld \\
\hline Juristen & 1,8 & laag \\
\hline Administratieve transportemployés & - & gemiddeld \\
\hline Leidinggevenden & 3,1 & gemiddeld \\
\hline Managers & 3,7 & gemiddeld \\
\hline Medisch secretaresses & 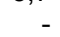 & gemiddeld \\
\hline Programmeurs & 1,5 & laag \\
\hline Systeemanalisten & 1,1 & erg laag \\
\hline Informatici & - & erg laag \\
\hline Technisch systeemanalisten & - & erg laag \\
\hline Act.begeleiders en medew. arbeidsbemiddeling & 3,2 & gemiddeld \\
\hline Sociaal-cultureel werkers & 2,6 & gemiddeld \\
\hline Sociale raadslieden en hoofden personeelszaken & - & erg hoog \\
\hline Sociaal-wetenschappelijk medewerkers & - & gemiddeld \\
\hline Sociaal-wetenschappelijk onderzoekers & - & laag \\
\hline Vakkenvullers & - & erg laag \\
\hline Interieurverzorgers & 3,9 & gemiddeld \\
\hline Verkopers & 2,3 & gemiddeld \\
\hline Winkeliers & 3,5 & gemiddeld \\
\hline Hulpkrachten horeca en verzorging & 4,2 & hoog \\
\hline Ziekenverzorgenden & 4,2 & hoog \\
\hline Verzorgend personeel & 2,7 & gemiddeld \\
\hline
\end{tabular}


Tabel 4.3 (vervolg)

Verwachte vervangingsvraag per beroepsgroep (als percentage van de werkgelegenheid), Overijssel, 2004

Beroepsgroep

$\% \quad$ typering

Café- en snackbarhouders

Bedrijfshoofden horeca

Bakkers en slagers

Asp. politie-agenten, soldaten en beveiligingshulpen

Agenten, onderofficieren en beveiligingsemployés

Politie-inspecteurs en officieren

Brandweerlieden

(1)

Totaal

erg hoog

hoog

- $\quad$ gemiddeld

6,2 erg hoog

4,1 hoog

- $\quad$ gemiddeld

laag

Bron: ROA 
Tabel 4.4

Verwachte baanopeningen per beroepsgroep (als percentage van de werkgelegenheid), Overijssel, 2004

\begin{tabular}{|c|c|c|}
\hline Beroepsgroep & $\%$ & typering \\
\hline Leraar basisonderwijs & 4,9 & gemiddeld \\
\hline Docenten exacte, med. en verz. vakken ( $2 \mathrm{e}+3 \mathrm{e}$ gr.) & - & gemiddeld \\
\hline Docenten exacte, med. en verz. vakken (1e gr.) & - & erg hoog \\
\hline Docenten landbouw en techniek (2e en 3e gr.) & - & erg hoog \\
\hline Docenten landbouw en techniek (1e gr. en WO) & - & erg hoog \\
\hline Docenten economisch-admin. vakken (2e en 3e gr.) & - & erg hoog \\
\hline Docenten economisch-admin. vakken (1e gr.) & - & laag \\
\hline Docenten talen en expressie & 5,1 & gemiddeld \\
\hline Docenten letteren (1e gr. en WO) & 6,9 & hoog \\
\hline Docenten sociale vakken ( $2 \mathrm{e}$ en $3 \mathrm{e}$ gr.) & - & erg hoog \\
\hline Docenten sociale vakken (1e gr.) & - & gemiddeld \\
\hline Docenten $2 \mathrm{e}$ en $3 e$ graads zonder specialisatie & - & gemiddeld \\
\hline Docent $1 \mathrm{e}$ graads zonder specialisatie & - & hoog \\
\hline Onderwijskundig medewerkers & - & gemiddeld \\
\hline Onderwijskundigen en pedagogen & - & hoog \\
\hline Rij-instructeurs & - & gemiddeld \\
\hline Zweminstructeurs & - & erg laag \\
\hline Sportinstructeurs & - & gemiddeld \\
\hline Tolken, vertalers en schrijvers & - & erg hoog \\
\hline Bibliotheekassistenten & - & laag \\
\hline Bibliothecarissen & - & erg hoog \\
\hline Grafisch ontwerpers & - & hoog \\
\hline Kunstenaars & 3,1 & gemiddeld \\
\hline Geestelijk verzorgers & - & erg hoog \\
\hline Geestelijken & - & gemiddeld \\
\hline Journalisten & - & erg hoog \\
\hline Taalkundigen & - & hoog \\
\hline Agrarische hulparbeiders & - & gemiddeld \\
\hline Agrarische arbeiders & 3,5 & gemiddeld \\
\hline Agrarische vakkrachten & - & laag \\
\hline Milieuhygiënisten en agrarisch vertegenwoordigers & - & hoog \\
\hline Landbouwkundigen & - & laag \\
\hline Landbouwmachinebestuurders en vissers & - & gemiddeld \\
\hline Agrarische bedriifshoofden & 8,8 & hoog \\
\hline Productiemedewerkers & 3,7 & gemiddeld \\
\hline Laboratoriumassistenten & - & gemiddeld \\
\hline Laboranten & - & laag \\
\hline Technisch analisten & - & erg hoog \\
\hline Natuurwetenschappers & - & gemiddeld \\
\hline Conciërges & 6 & gemiddeld \\
\hline Hoofden technische dienst & - & hoog \\
\hline Werktuigbouwkundigen & - & erg hoog \\
\hline Bouwvakkers & 4,7 & gemiddeld \\
\hline Aannemers en installateurs & 8,3 & hoog \\
\hline Architecten en bouwkundig projectleiders & 3 & laag \\
\hline Weg- en waterbouwkundigen & - & gemiddeld \\
\hline Weg- en waterbouwkundige arbeiders & - & gemiddeld \\
\hline Weg- en waterbouwkundige vakkrachten & 13,6 & erg hoog \\
\hline Weg- en waterbouwkundig ontwerpers en projectleiders & & gemiddeld \\
\hline Metaalarbeiders & 4,4 & gemiddeld \\
\hline Bankwerkers en lassers & 6,1 & hoog \\
\hline Bedrijfshoofden metaalbewerking & - & gemiddeld \\
\hline Assembleurs & - & gemiddeld \\
\hline Monteurs & 3,7 & gemiddeld \\
\hline Werktuigbouwk. ontwerpers en hoofden techn. dienst & $\begin{array}{r}\sqrt{1}, 1 \\
4\end{array}$ & gemiddeld \\
\hline Elektronicamonteurs & - & hoog \\
\hline Monteurs en controleurs elektrotechn. producten & - & gemiddeld \\
\hline Elektromonteurs & 9,6 & hoog \\
\hline Electrotechnisch ontwerpers en bedrijfshoofden & - & gemiddeld \\
\hline Elektrotechnici & - & laag \\
\hline
\end{tabular}


Tabel 4.4 (vervolg)

Verwachte baanopeningen per beroepsgroep (als percentage van de werkgelegenheid), Overijssel, 2004

Beroepsgroep

$\% \quad$ typering

Grafisch productiepersoneel

Grafische vakkrachten

Mechanisch operators

Procesoperators

Procestechnologen

Materiaalkundigen

Confectie-arbeiders

Schoen- en kleermakers

Laders en lossers

typering

Chauffeurs

Schippers en conducteurs

Vliegers, scheepskapiteins en leidinggevenden transport

Stewards

Verpleeghulpen en leerling-verpleegkundigen

Verplegenden en doktersassistenten

Therapeuten en verpleegkundigen

Artsen

Apothekersassistenten en medisch laboranten

Medisch analisten

Apothekers

Afdelingshoofden zorginstelling

Kantoorhulpen, inpakkers en colporteurs

Ondersteunende administratieve hulpkrachten

Bedrijfshoofden

Economen

Productieplanners

Organisatie-adviseurs

Organisatiedeskundigen

Receptionisten en administratieve employés

Boekhouders en secretaresses

Assistent accountants

Accountants

Verzekeringsagenten

Commercieel employés

Commercieel medewerkers

Technisch-commercieel employés

Technisch-bedrijfskundig medewerkers

Juridisch en fiscaal medewerkers

Juridisch, bestuurlijk medewerkers

Juristen

Administratieve transportemployés

Leidinggevenden

Managers

Medisch secretaresses

Programmeurs

Systeemanalisten

Informatici

Technisch systeemanalisten

Act.begeleiders en medew. arbeidsbemiddeling

Sociaal-cultureel werkers

Sociale raadslieden en hoofden personeelszaken

Sociaal-wetenschappelijk medewerkers

Sociaal-wetenschappelijk onderzoekers

Vakkenvullers

Interieurverzorgers

Verkopers

Winkeliers

Hulpkrachten horeca en verzorging

Ziekenverzorgenden

Verzorgend personeel

6,8

6,8
6,9

5,6

-

11,

11,2

3,3

4,3

-

-

-

3,4

2,5

4,3

1,7

-

-

4,4

3,8

7

4,4

2,5

4,2

4,2
2,3

2,3
4,8
2

1,9

5,1

-

15,7

3,5

3,5

6,8

8,1

2,7

2,7
4,8

4,8
-
-

5,8

6,6

-

$-$

-

4,2

2,3

8,4

4,2

4,2
7,5

2,7 gemiddeld

hoog

hoog

gemiddeld

hoog

erg hoog

hoog

gemiddeld

gemiddeld

gemiddeld

laag

hoog

gemiddeld

laag

gemiddeld

laag

gemiddeld

laag

laag

gemiddeld

gemiddeld

gemiddeld

laag

gemiddeld

erg laag

hoog

gemiddeld

laag

laag

gemiddeld

laag

gemiddeld

laag

laag

gemiddeld

hoog

gemiddeld

erg hoog

gemiddeld

gemiddeld

laag

hoog

hoog

laag

laag

gemiddeld

laag

hoog

gemiddeld

hoog

hoog

gemiddeld

laag

laag

gemiddeld

laag

hoog

gemiddeld

hoog

laag 
Tabel 4.4 (vervolg)

Verwachte baanopeningen per beroepsgroep (als percentage van de werkgelegenheid), Overijssel, 2004

Beroepsgroep

Café- en snackbarhouders

Bedrijfshoofden horeca

Bakkers en slagers

Asp. politie-agenten, soldaten en beveiligingshulpen

Agenten, onderofficieren en beveiligingsemployés

Politie-inspecteurs en officieren

Brandweerlieden

Totaal

Bron: ROA typering

hoog

gemiddeld

- $\quad$ gemiddeld

6,2 hoog

4,1 gemiddeld

- $\quad$ laag

laag

5 
Tabel 4.5

Indicator Toekomstige Knelpunten in de personeelsvoorziening per Beroep (ITKB) per beroepsgroep, Overijssel, 2004 (alleen elementaire, lagere en middelbare beroepen)

\begin{tabular}{|c|c|c|}
\hline Beroepsgroep & ITKB & typering \\
\hline Rij-instructeurs & - & groot \\
\hline Zweminstructeurs & - & vrijwel geen \\
\hline Sportinstructeurs & - & groot \\
\hline Agrarische hulparbeiders & - & enige \\
\hline Agrarische arbeiders & 1,04 & enige \\
\hline Agrarische vakkrachten & - & vrijwel geen \\
\hline Landbouwmachinebestuurders en vissers & - & vrijwel geen \\
\hline Agrarische bedrijfshoofden & 1,00 & groot \\
\hline Productiemedewerkers & 1,14 & vrijwel geen \\
\hline Laboratoriumassistenten & - & vrijwel geen \\
\hline Laboranten & - & vrijwel geen \\
\hline Conciërges & 1,00 & groot \\
\hline Hoofden technische dienst & - & groot \\
\hline Bouwvakkers & 1,08 & vrijwel geen \\
\hline Aannemers en installateurs & 0,98 & groot \\
\hline Weg- en waterbouwkundige arbeiders & - & geen \\
\hline Weg- en waterbouwkundige vakkrachten & 0,96 & groot \\
\hline Metaalarbeiders & 1,01 & enige \\
\hline Bankwerkers en lassers & 0,99 & groot \\
\hline Assembleurs & - & enige \\
\hline Monteurs & 1,10 & vrijwel geen \\
\hline Elektronicamonteurs & - & groot \\
\hline Monteurs en controleurs elektrotechn. producten & - & vrijwel geen \\
\hline Elektromonteurs & 0,96 & groot \\
\hline Grafisch productiepersoneel & - & vrijwel geen \\
\hline Grafische vakkrachten & 1,00 & groot \\
\hline Mechanisch operators & 0,97 & groot \\
\hline Procesoperators & 0,94 & groot \\
\hline Confectie-arbeiders & 0,95 & groot \\
\hline Schoen- en kleermakers & - & geen \\
\hline Laders en lossers & 1,07 & vrijwel geen \\
\hline Chauffeurs & 1,04 & enige \\
\hline Schippers en conducteurs & - & enige \\
\hline Stewards & - & enige \\
\hline Verpleeghulpen en leerling-verpleegkundigen & - & vrijwel geen \\
\hline Verplegenden en doktersassistenten & 0,98 & groot \\
\hline Apothekersassistenten en medisch laboranten & 1,01 & enige \\
\hline Kantoorhulpen, inpakkers en colporteurs & 1,03 & enige \\
\hline Ondersteunende administratieve hulpkrachten & - & geen \\
\hline Receptionisten en administratieve employés & 1,08 & vrijwel geen \\
\hline Verzekeringsagenten & 1,07 & vrijwel geen \\
\hline Administratieve transportemployés & - & enige \\
\hline Medisch secretaresses & - & enige \\
\hline Vakkenvullers & - & vrijwel geen \\
\hline Interieurverzorgers & 1,01 & enige \\
\hline Verkopers & 1,07 & vrijwel geen \\
\hline Hulpkrachten horeca en verzorging & 1,01 & enige \\
\hline Ziekenverzorgenden & 0,97 & groot \\
\hline Café- en snackbarhouders & - & groot \\
\hline Bakkers en slagers & - & vrijwel geen \\
\hline Asp. politie-agenten, soldaten en beveiligingshulpen & 1,05 & enige \\
\hline Brandweerlieden & - & groot \\
\hline
\end{tabular}

Bron: ROA 
Tabel 4.6

Verwachte uitbreidingsvraag per opleidingstype (als percentage van de werkgelegenheid), Overijssel, 2004

\begin{tabular}{|c|c|c|}
\hline Opleidingstype & $\%$ & typering \\
\hline Basisonderwijs & $-1,2$ & laag \\
\hline VMBO theorie & $-1,4$ & erg laag \\
\hline VMBO landbouw en natuurlijke omgeving & $-1,1$ & laag \\
\hline VMBO bouwtechniek & $-1,5$ & erg laag \\
\hline VMBO installatietechniek & - & laag \\
\hline VMBO mechanische techniek & $-1,1$ & laag \\
\hline VMBO fijnmechanische techniek & - & erg laag \\
\hline VMBO motorvoertuigentechniek & - & laag \\
\hline VMBO elektrotechniek & $-0,7$ & laag \\
\hline VMBO grafische techniek & - & erg laag \\
\hline VMBO brood en banket & - & erg laag \\
\hline VMBO horeca en levensmiddelentechniek & - & erg laag \\
\hline VMBO vervoer & $-0,4$ & gemiddeld \\
\hline VMBO administratie, handel en textiel & $-1,4$ & erg laag \\
\hline VMBO verzorging & $-1,8$ & erg laag \\
\hline VMBO beveiliging & - & erg laag \\
\hline HAVO/VWO & $-0,2$ & gemiddeld \\
\hline MBO voeding, natuur en milieu & $-0,9$ & laag \\
\hline MBO groene ruimte & & laag \\
\hline MBO bouw & $-0,7$ & laag \\
\hline MBO grond-, weg- en waterbouw & - & gemiddeld \\
\hline MBO installatietechniek & - & gemiddeld \\
\hline MBO werktuigbouw en mechanische techniek & $-0,1$ & gemiddeld \\
\hline MBO fijnmechanische techniek en laboratorium & $-0,3$ & gemiddeld \\
\hline MBO motorvoertuigentechniek en tweewielers & $-0,2$ & gemiddeld \\
\hline MBO vliegtuigtechniek & - & gemiddeld \\
\hline MBO operationele techniek & - & gemiddeld \\
\hline MBO elektrotechniek & 0,1 & gemiddeld \\
\hline MBO grafische techniek & $-0,9$ & laag \\
\hline MBO procestechniek & $-0,2$ & gemiddeld \\
\hline MBO brood en banket & - & gemiddeld \\
\hline MBO levensmiddelentechniek/vleesverwerking & - & laag \\
\hline MBO vervoer & 0 & gemiddeld \\
\hline MBO dokters-, tandarts- en dierenartsassistent & - & hoog \\
\hline MBO apothekersassistent & - & hoog \\
\hline MBO verpleging en verzorging & 0,3 & gemiddeld \\
\hline MBO gezondheidstechniek & - & hoog \\
\hline MBO sociaal-pedagogisch en welzijn & 0 & gemiddeld \\
\hline MBO uiterlijke verzorging & $-1,1$ & laag \\
\hline MBO horeca & $-0,9$ & laag \\
\hline MBO bewegingen therapie & & gemiddeld \\
\hline MBO administratie en logistiek & 0,3 & gemiddeld \\
\hline MBO handel & $-0,4$ & laag \\
\hline MBO secretariaat & 0,2 & gemiddeld \\
\hline MBO toerisme en recreatie & & gemiddeld \\
\hline MBO facilitaire dienstverlening & 0,8 & hoog \\
\hline MBO ICT & 0,6 & gemiddeld \\
\hline MBO geld, bank en belastingen & 1,1 & hoog \\
\hline MBO verzekeringswezen & 0,6 & gemiddeld \\
\hline MBO openbare orde en veiligheid & $-0,2$ & gemiddeld \\
\hline HBO lerarenopleiding basisonderwijs & -1 & laag \\
\hline HBO lerarenopleiding talen & 0,1 & gemiddeld \\
\hline HBO lerarenopleiding natuur en techniek & $-0,4$ & laag \\
\hline HBO lerarenopleiding economie en maatschappij & 0,8 & hoog \\
\hline HBO lerarenopleiding lichamelijke opvoeding & . & laag \\
\hline HBO lerarenopleiding medisch en verzorging & - & gemiddeld \\
\hline
\end{tabular}


Tabel 4.6 (vervolg)

Verwachte uitbreidingsvraag per opleidingstype (als percentage van de werkgelegenheid), Overijssel, 2004

\begin{tabular}{|c|c|c|}
\hline Opleidingstype & $\%$ & typering \\
\hline HBO lerarenopleiding expressie & - & laag \\
\hline HBO tolk en vertaler & - & gemiddeld \\
\hline HBO landbouw en veeteelt & - & gemiddeld \\
\hline HBO milieukunde en levensmiddelentechnologie & - & gemiddeld \\
\hline HBO laboratorium & 3,3 & erg hoog \\
\hline HBO bouwkunde & - & gemiddeld \\
\hline HBO civiele techniek & - & gemiddeld \\
\hline HBO werktuigbouwkunde & 0,1 & gemiddeld \\
\hline HBO elektrotechniek & 0,3 & gemiddeld \\
\hline HBO informatica & 1,6 & erg hoog \\
\hline HBO chemische technologie & - & gemiddeld \\
\hline HBO vervoer en logistiek & - & erg hoog \\
\hline HBO verpleegkunde & 1,1 & hoog \\
\hline HBO (fysio)therapie & 0,4 & gemiddeld \\
\hline HBO voeding & - & gemiddeld \\
\hline HBO radiologie & - & gemiddeld \\
\hline HBO accountancy en bedrijfseconomie & 1,2 & hoog \\
\hline HBO commerciële economie & 1,5 & erg hoog \\
\hline HBO toerisme en recreatie & - & hoog \\
\hline HBO recht en bestuur & 0,8 & hoog \\
\hline HBO secretariaat & 0,9 & hoog \\
\hline HBO bedrijfskunde & 1,5 & erg hoog \\
\hline HBO communicatie en journalistiek & - & erg hoog \\
\hline HBO maatschappelijk werk en hulpverlening & 2,2 & erg hoog \\
\hline HBO personeelswerk & - & erg hoog \\
\hline HBO bibliotheek en documentatie & - & erg laag \\
\hline HBO uitvoerende en beeldende kunsten & $-0,4$ & laag \\
\hline HBO openbare orde en veiligheid & - & hoog \\
\hline WO letteren & 1,1 & hoog \\
\hline WO theologie & - & gemiddeld \\
\hline WO landbouw en milieukunde & - & gemiddeld \\
\hline WO wiskunde en natuurwetenschappen & 1,2 & hoog \\
\hline WO bouwkunde & - & erg laag \\
\hline WO civiele techniek & _ & gemiddeld \\
\hline WO werktuigbouwkunde & - & laag \\
\hline WO elektrotechniek & - & gemiddeld \\
\hline WO informatica en bestuurlijke informatiekunde & - & hoog \\
\hline WO (dier)geneeskunde & 1,7 & erg hoog \\
\hline WO tandheelkunde & - & erg hoog \\
\hline WO farmacie en medische biologie & - & erg hoog \\
\hline WO econom(etr)ie & 1,4 & hoog \\
\hline WO bedrijfskunde & 1,3 & hoog \\
\hline WO accountancy en belastingen & - & hoog \\
\hline WO rechten en bestuurskunde & 1,3 & hoog \\
\hline WO sociale wetenschappen & 1,3 & hoog \\
\hline WO kunstwetenschappen & - & gemiddeld \\
\hline Totaal & $-0,1$ & - \\
\hline
\end{tabular}

Bron: ROA 
Tabel 4.7

Verwachte vervangingsvraag per opleidingstype (als percentage van de werkgelegenheid), Overijssel, 2004

\begin{tabular}{|c|c|c|}
\hline Opleidingstype & $\%$ & typering \\
\hline Basisonderwijs & 7,7 & erg hoog \\
\hline VMBO theorie & 4,6 & gemiddeld \\
\hline VMBO landbouw en natuurlijke omgeving & 5,9 & hoog \\
\hline VMBO bouwtechniek & 4,6 & hoog \\
\hline VMBO installatietechniek & - & gemiddeld \\
\hline VMBO mechanische techniek & 6,5 & erg hoog \\
\hline VMBO fijnmechanische techniek & - & laag \\
\hline VMBO motorvoertuigentechniek & _ & erg hoog \\
\hline VMBO elektrotechniek & 5,2 & hoog \\
\hline VMBO grafische techniek & - & erg hoog \\
\hline VMBO brood en banket & - & hoog \\
\hline VMBO horeca en levensmiddelentechniek & - & hoog \\
\hline VMBO vervoer & 6,1 & erg hoog \\
\hline VMBO administratie, handel en textiel & 6 & erg hoog \\
\hline VMBO verzorging & 4,9 & hoog \\
\hline VMBO beveiliging & - & hoog \\
\hline HAVO/VWO & 5,6 & hoog \\
\hline $\mathrm{MBO}$ voeding, natuur en milieu & 3,9 & gemiddeld \\
\hline MBO groene ruimte & - & gemiddeld \\
\hline MBO bouw & 5,1 & hoog \\
\hline MBO grond-, weg- en waterbouw & - & gemiddelo \\
\hline MBO installatietechniek & - & gemiddeld \\
\hline MBO werktuigbouw en mechanische techniek & 5,5 & hoog \\
\hline MBO fijnmechanische techniek en laboratorium & 4,1 & gemiddeld \\
\hline MBO motorvoertuigentechniek en tweewielers & 4,9 & hoog \\
\hline MBO vliegtuigtechniek & - & laag \\
\hline MBO operationele techniek & - & gemiddeld \\
\hline MBO elektrotechniek & 4,6 & gemiddeld \\
\hline MBO grafische techniek & 4,5 & gemiddeld \\
\hline MBO procestechniek & 1,9 & laag \\
\hline MBO brood en banket & - & gemiddeld \\
\hline MBO levensmiddelentechniek/vleesverwerking & - & gemiddeld \\
\hline MBO vervoer & 4,7 & hoog \\
\hline MBO dokters-, tandarts- en dierenartsassistent & - & gemiddeld \\
\hline MBO apothekersassistent & - & gemiddeld \\
\hline MBO verpleging en verzorging & 4,2 & gemiddeld \\
\hline MBO gezondheidstechniek & & gemiddeld \\
\hline MBO sociaal-pedagogisch en welzijn & 4,2 & gemiddeld \\
\hline MBO uiterlijke verzorging & 2,3 & laag \\
\hline MBO horeca & 2,7 & gemiddeld \\
\hline MBO bewegingen therapie & - & gemiddelo \\
\hline MBO administratie en logistiek & 4,1 & gemiddeld \\
\hline MBO handel & 3,7 & gemiddeld \\
\hline MBO secretariaat & 2,7 & gemiddeld \\
\hline MBO toerisme en recreatie & - & erg hoog \\
\hline MBO facilitaire dienstverlening & 6,3 & erg hoog \\
\hline MBO ICT & 3 & gemiddeld \\
\hline MBO geld, bank en belastingen & 5,4 & hoog \\
\hline MBO verzekeringswezen & 5,2 & hoog \\
\hline MBO openbare orde en veiligheid & 4,2 & gemiddeld \\
\hline HBO lerarenopleiding basisonderwijs & 4 & gemiddeld \\
\hline HBO lerarenopleiding talen & 5,8 & hoog \\
\hline HBO lerarenopleiding natuur en techniek & 3,3 & gemiddeld \\
\hline HBO lerarenopleiding economie en maatschappij & 6,5 & erg hoog \\
\hline HBO lerarenopleiding lichamelijke opvoeding & - & hoog \\
\hline HBO lerarenopleiding medisch en verzorging & - & hoog \\
\hline
\end{tabular}


Tabel 4.7 (vervolg)

Verwachte vervangingsvraag per opleidingstype (als percentage van de werkgelegenheid), Overijssel, 2004

\begin{tabular}{|c|c|c|}
\hline Opleidingstype & $\%$ & typering \\
\hline HBO lerarenopleiding expressie & - & erg hoog \\
\hline HBO tolk en vertaler & - & erg laag \\
\hline HBO landbouw en veeteelt & - & laag \\
\hline HBO milieukunde en levensmiddelentechnologie & _ & gemiddeld \\
\hline HBO laboratorium & 3,2 & gemiddeld \\
\hline HBO bouwkunde & - & gemiddeld \\
\hline HBO civiele techniek & - & gemiddeld \\
\hline HBO werktuigbouwkunde & 4 & gemiddeld \\
\hline HBO elektrotechniek & 4,7 & hoog \\
\hline HBO informatica & 2,3 & gemiddeld \\
\hline HBO chemische technologie & - & hoog \\
\hline HBO vervoer en logistiek & - & laag \\
\hline HBO verpleegkunde & 2,7 & gemiddeld \\
\hline HBO (fysio)therapie & 4,6 & hoog \\
\hline HBO voeding & - & erg laag \\
\hline HBO radiologie & - & laag \\
\hline HBO accountancy en bedrijfseconomie & 2,6 & gemiddeld \\
\hline HBO commerciële economie & 1,9 & laag \\
\hline HBO toerisme en recreatie & - & erg laag \\
\hline HBO recht en bestuur & 2,5 & gemiddeld \\
\hline HBO secretariaat & 4,1 & gemiddeld \\
\hline HBO bedrijfskunde & 2 & laag \\
\hline HBO communicatie en journalistiek & - & laag \\
\hline HBO maatschappelijk werk en hulpverlening & 4,8 & hoog \\
\hline HBO personeelswerk & - & hoog \\
\hline HBO bibliotheek en documentatie & - & laag \\
\hline HBO uitvoerende en beeldende kunsten & 4,2 & gemiddeld \\
\hline HBO openbare orde en veiligheid & - & laag \\
\hline WO letteren & 1 & erg laag \\
\hline WO theologie & - & gemiddeld \\
\hline WO landbouw en milieukunde & - & laag \\
\hline WO wiskunde en natuurwetenschappen & 2,2 & laag \\
\hline WO bouwkunde & - & gemiddeld \\
\hline WO civiele techniek & - & laag \\
\hline WO werktuigbouwkunde & - & gemiddeld \\
\hline WO elektrotechniek & - & laag \\
\hline WO informatica en bestuurlijke informatiekunde & - & erg laag \\
\hline WO (dier)geneeskunde & 2,1 & laag \\
\hline WO tandheelkunde & - & gemiddeld \\
\hline WO farmacie en medische biologie & _ & erg laag \\
\hline WO econom(etr)ie & 1,4 & laag \\
\hline WO bedriifskunde & 1,1 & laag \\
\hline WO accountancy en belastingen & - & laag \\
\hline WO rechten en bestuurskunde & 1,2 & laag \\
\hline WO sociale wetenschappen & 2,5 & gemiddeld \\
\hline WO kunstwetenschappen & - & erg laag \\
\hline Totaal & 4,2 & - \\
\hline
\end{tabular}

Bron: ROA 
Tabel 4.8

Verwachte baanopeningen per opleidingstype (als percentage van de werkgelegenheid), Overijssel, 2004

\begin{tabular}{|c|c|c|}
\hline Opleidingstype & $\%$ & typering \\
\hline Basisonderwijs & 7,7 & erg hoog \\
\hline VMBO theorie & 4,6 & gemiddeld \\
\hline VMBO landbouw en natuurlijke omgeving & 5,9 & hoog \\
\hline VMBO bouwtechniek & 4,6 & gemiddeld \\
\hline VMBO installatietechniek & - & gemiddeld \\
\hline VMBO mechanische techniek & 6,5 & erg hoog \\
\hline VMBO fijnmechanische techniek & - & laag \\
\hline VMBO motorvoertuigentechniek & - & erg hoog \\
\hline VMBO elektrotechniek & 5,2 & hoog \\
\hline VMBO grafische techniek & - & erg hoog \\
\hline VMBO brood en banket & - & hoog \\
\hline VMBO horeca en levensmiddelentechniek & - & gemiddeld \\
\hline VMBO vervoer & 6,1 & hoog \\
\hline VMBO administratie, handel en textiel & 6 & hoog \\
\hline VMBO verzorging & 4,9 & hoog \\
\hline VMBO beveiliging & - & hoog \\
\hline HAVO/VWO & 5,6 & hoog \\
\hline MBO voeding, natuur en milieu & 3,9 & gemiddeld \\
\hline MBO groene ruimte & & laag \\
\hline MBO bouw & 5,1 & hoog \\
\hline MBO grond-, weg- en waterbouw & - & gemiddeld \\
\hline MBO installatietechniek & - & gemiddeld \\
\hline MBO werktuigbouw en mechanische techniek & 5,5 & hoog \\
\hline MBO fijnmechanische techniek en laboratorium & 4,1 & gemiddeld \\
\hline MBO motorvoertuigentechniek en tweewielers & 4,9 & hoog \\
\hline MBO vliegtuigtechniek & - & erg laag \\
\hline MBO operationele techniek & - & gemiddeld \\
\hline MBO elektrotechniek & 4,6 & gemiddeld \\
\hline MBO grafische techniek & 4,5 & gemiddeld \\
\hline MBO procestechniek & 1,9 & laag \\
\hline MBO brood en banket & - & gemiddeld \\
\hline MBO levensmiddelentechniek/vleesverwerking & - & gemiddeld \\
\hline MBO vervoer & 4,7 & gemiddeld \\
\hline MBO dokters-, tandarts- en dierenartsassistent & - & gemiddeld \\
\hline MBO apothekersassistent & - & hoog \\
\hline MBO verpleging en verzorging & 4,6 & gemiddeld \\
\hline MBO gezondheidstechniek & - & gemiddeld \\
\hline MBO sociaal-pedagogisch en welzijn & 4,2 & gemiddeld \\
\hline MBO uiterlijke verzorging & 2,3 & laag \\
\hline MBO horeca & 2,7 & laag \\
\hline MBO bewegingen therapie & & gemiddeld \\
\hline MBO administratie en logistiek & 4,5 & gemiddeld \\
\hline MBO handel & 3,7 & gemiddeld \\
\hline MBO secretariaat & 2,9 & laag \\
\hline MBO toerisme en recreatie & - & erg hoog \\
\hline MBO facilitaire dienstverlening & 7,1 & erg hoog \\
\hline MBO ICT & 3,6 & gemiddeld \\
\hline MBO geld, bank en belastingen & 6,5 & hoog \\
\hline MBO verzekeringswezen & 5,9 & hoog \\
\hline MBO openbare orde en veiligheid & 4,2 & gemiddeld \\
\hline HBO lerarenopleiding basisonderwijs & 4 & gemiddeld \\
\hline HBO lerarenopleiding talen & 5,9 & hoog \\
\hline HBO lerarenopleiding natuur en techniek & 3,3 & gemiddeld \\
\hline HBO lerarenopleiding economie en maatschappij & 7,3 & erg hoog \\
\hline HBO lerarenopleiding lichamelijke opvoeding & - & gemiddeld \\
\hline HBO lerarenopleiding medisch en verzorging & - & hoog \\
\hline
\end{tabular}


Tabel 4.8 (vervolg)

Verwachte baanopeningen per opleidingstype (als percentage van de werkgelegenheid), Overijssel, 2004

\begin{tabular}{|c|c|c|}
\hline Opleidingstype & $\%$ & typering \\
\hline $\begin{array}{l}\text { HBO lerarenopleiding expressie } \\
\text { HBO tolk en vertaler } \\
\text { HBO landbouw en veeteelt } \\
\text { HBO milieukunde en levensmiddelentechnologie } \\
\text { HBO laboratorium } \\
\text { HBO bouwkunde } \\
\text { HBO civiele techniek } \\
\text { HBO werktuigbouwkunde } \\
\text { HBO elektrotechniek } \\
\text { HBO informatica } \\
\text { HBO chemische technologie } \\
\text { HBO vervoer en logistiek } \\
\text { HBO verpleegkunde } \\
\text { HBO (fysio)therapie } \\
\text { HBO voeding } \\
\text { HBO radiologie } \\
\text { HBO accountancy en bedrijfseconomie } \\
\text { HBO commerciële economie } \\
\text { HBO toerisme en recreatie } \\
\text { HBO recht en bestuur } \\
\text { HBO secretariaat } \\
\text { HBO bedrijfskunde } \\
\text { HBO communicatie en journalistiek } \\
\text { HBO maatschappelijk werk en hulpverlening } \\
\text { HBO personeelswerk } \\
\text { HBO bibliotheek en documentatie } \\
\text { HBO uitvoerende en beeldende kunsten } \\
\text { HBO openbare orde en veiligheid }\end{array}$ & $\begin{array}{r}- \\
- \\
- \\
6,5 \\
- \\
- \\
4,1 \\
5,1 \\
3,9 \\
- \\
- \\
3,8 \\
4,9 \\
- \\
- \\
3,9 \\
3,4 \\
- \\
3,3 \\
5 \\
3,5 \\
- \\
6,9 \\
- \\
- \\
4,2 \\
-\end{array}$ & $\begin{array}{l}\text { hoog } \\
\text { erg laag } \\
\text { laag } \\
\text { gemiddeld } \\
\text { erg hoog } \\
\text { laag } \\
\text { gemiddeld } \\
\text { gemiddeld } \\
\text { hoog } \\
\text { gemiddeld } \\
\text { hoog } \\
\text { laag } \\
\text { gemiddeld } \\
\text { hoog } \\
\text { erg laag } \\
\text { laag } \\
\text { gemiddeld } \\
\text { gemiddeld } \\
\text { erg laag } \\
\text { gemiddeld } \\
\text { hoog } \\
\text { gemiddeld } \\
\text { gemiddeld } \\
\text { erg hoog } \\
\text { erg hoog } \\
\text { laag } \\
\text { gemiddeld } \\
\text { gemiddeld }\end{array}$ \\
\hline $\begin{array}{l}\text { WO letteren } \\
\text { WO theologie } \\
\text { WO landbouw en milieukunde } \\
\text { WO wiskunde en natuurwetenschappen } \\
\text { WO bouwkunde } \\
\text { WO civiele techniek } \\
\text { WO werktuigbouwkunde } \\
\text { WO elektrotechniek } \\
\text { WO informatica en bestuurlijke informatiekunde } \\
\text { WO (dier)geneeskunde } \\
\text { WO tandheelkunde } \\
\text { WO farmacie en medische biologie } \\
\text { WO econom(etr)ie } \\
\text { WO bedrijfskunde } \\
\text { WO accountancy en belastingen } \\
\text { WO rechten en bestuurskunde } \\
\text { WO sociale wetenschappen } \\
\text { WO kunstwetenschappen }\end{array}$ & $\begin{array}{r}2 \\
- \\
- \\
3,4 \\
- \\
- \\
- \\
- \\
- \\
3,8 \\
- \\
- \\
2,8 \\
2,4 \\
2,6 \\
3,8 \\
-\end{array}$ & $\begin{array}{l}\text { laag } \\
\text { laag } \\
\text { laag } \\
\text { gemiddeld } \\
\text { gemiddeld } \\
\text { laag } \\
\text { laag } \\
\text { laag } \\
\text { erg laag } \\
\text { gemiddeld } \\
\text { hoog } \\
\text { erg laag } \\
\text { laag } \\
\text { laag } \\
\text { laag } \\
\text { laag } \\
\text { gemiddeld } \\
\text { erg laag }\end{array}$ \\
\hline Totaal & 4,6 & - \\
\hline
\end{tabular}

Bron: ROA 
Tabel 4.9

Verwachte arbeidsmarktinstroom van schoolverlaters per opleidingstype (als percentage van de werkgelegenheid), Overijssel, 2004 (alleen lagere en middelbare opleidingen)

\begin{tabular}{|c|c|c|}
\hline Opleidingstype & $\%$ & typering \\
\hline Basisonderwijs & 4,9 & gemiddeld \\
\hline VMBO theorie & 4,6 & gemiddeld \\
\hline VMBO landbouw en natuurlijke omgeving & 7,3 & hoog \\
\hline VMBO bouwtechniek & 4,1 & gemiddeld \\
\hline VMBO installatietechniek & - & gemiddeld \\
\hline VMBO mechanische techniek & 2,8 & gemiddeld \\
\hline VMBO fijnmechanische techniek & - & erg laag \\
\hline VMBO motorvoertuigentechniek & - & gemiddeld \\
\hline VMBO elektrotechniek & 4,1 & gemiddeld \\
\hline VMBO grafische techniek & - & hoog \\
\hline VMBO brood en banket & - & hoog \\
\hline VMBO horeca en levensmiddelentechniek & - & laag \\
\hline VMBO vervoer & 0,4 & erg laag \\
\hline VMBO administratie, handel en textiel & 9 & hoog \\
\hline VMBO verzorging & 6,7 & hoog \\
\hline VMBO beveiliging & - & erg hoog \\
\hline HAVO/NWO & 7,2 & hoog \\
\hline MBO voeding, natuur en milieu & 9,5 & erg hoog \\
\hline MBO groene ruimte & & erg hoog \\
\hline MBO bouw & 10,4 & erg hoog \\
\hline MBO grond-, weg- en waterbouw & - & erg hoog \\
\hline MBO installatietechniek & - & hoog \\
\hline MBO werktuigbouw en mechanische techniek & 4 & gemiddeld \\
\hline MBO fijnmechanische techniek en laboratorium & 3,5 & gemiddeld \\
\hline MBO motorvoertuigentechniek en tweewielers & 7,8 & hoog \\
\hline MBO vliegtuigtechniek & - & gemiddeld \\
\hline MBO operationele techniek & - & gemiddeld \\
\hline MBO elektrotechniek & 5,8 & hoog \\
\hline MBO grafische techniek & 21,4 & erg hoog \\
\hline MBO procestechniek & 4,9 & gemiddeld \\
\hline MBO brood en banket & - & gemiddeld \\
\hline MBO levensmiddelentechniek/vleesverwerking & - & erg hoog \\
\hline MBO vervoer & 4,9 & gemiddeld \\
\hline MBO dokters-, tandarts- en dierenartsassistent & - & erg hoog \\
\hline MBO apothekersassistent & - & erg hoog \\
\hline MBO verpleging en verzorging & 2,1 & laag \\
\hline MBO gezondheidstechniek & - & hoog \\
\hline MBO sociaal-pedagogisch en welzijn & 7,8 & hoog \\
\hline MBO uiterlijke verzorging & 7,1 & hoog \\
\hline MBO horeca & 9,4 & erg hoog \\
\hline MBO bewegingen therapie & - & gemiddeld \\
\hline MBO administratie en logistiek & 5 & gemiddeld \\
\hline MBO handel & 3,8 & gemiddeld \\
\hline MBO secretariaat & 4,5 & gemiddeld \\
\hline MBO toerisme en recreatie & . & hoog \\
\hline MBO facilitaire dienstverlening & 7,8 & hoog \\
\hline MBO ICT & 5,4 & hoog \\
\hline MBO geld, bank en belastingen & 1,4 & laag \\
\hline MBO verzekeringswezen & 3,5 & gemiddeld \\
\hline MBO openbare orde en veiligheid & 2 & laag \\
\hline Totaal (incl. HBO en WO) & 5 & - \\
\hline
\end{tabular}

Bron: ROA 
Tabel 4.10

Indicator Toekomstperspectieven op de Arbeidsmarkt voor schoolverlaters (ITA) en Indicator Toekomstige knelpunten in de Personeelsvoorziening (ITKP) per opleidingstype, Overijssel, 2004 (alleen lagere en middelbare opleidingen)

\begin{tabular}{|c|c|c|c|c|}
\hline Opleidingstype & ITA & typering & ITKP & typering \\
\hline Basisonderwijs & 0,97 & goed & 0,98 & groot \\
\hline VMBO theorie & 1 & goed & 1,01 & enige \\
\hline VMBO landbouw en natuurlijke omgeving & 1,01 & redelijk & 1,02 & enige \\
\hline VMBO bouwtechniek & 1 & goed & 1,01 & enige \\
\hline VMBO installatietechniek & - & redelijk & - & enige \\
\hline VMBO mechanische techniek & 0,97 & goed & 0,98 & groot \\
\hline VMBO fijnmechanische techniek & - & goed & - & groot \\
\hline VMBO motorvoertuigentechniek & - & goed & - & groot \\
\hline VMBO elektrotechniek & 0,99 & goed & 1 & groot \\
\hline VMBO grafische techniek & - & goed & - & enige \\
\hline VMBO brood en banket & - & goed & - & enige \\
\hline VMBO horeca en levensmiddelentechniek & - & goed & - & groot \\
\hline VMBO vervoer & 0,95 & goed & 0,95 & groot \\
\hline VMBO administratie, handel en textiel & 1,03 & redelijk & 1,04 & enige \\
\hline VMBO verzorging & 1,02 & redelijk & 1,04 & enige \\
\hline VMBO beveiliging & - & slecht & - & geen \\
\hline HAVO/MWO & 1,02 & redelijk & 1,02 & enige \\
\hline MBO voeding, natuur en milieu & 1,05 & redelijk & 1,06 & vrijwel geen \\
\hline MBO groene ruimte & - & matig & - & vrijwel geen \\
\hline MBO bouw & 1,05 & redelijk & 1,06 & vrijwel geen \\
\hline MBO grond-, weg- en waterbouw & - & matig & - & vrijwel geen \\
\hline MBO installatietechniek & - & redelijk & - & enige \\
\hline MBO werktuigbouw en mechanische techniek & 0,99 & goed & 0,99 & groot \\
\hline MBO fijnmechanische techniek en laboratorium & 0,99 & goed & 1 & groot \\
\hline MBO motorvoertuigentechniek en tweewielers & 1,03 & redelijk & 1,03 & enige \\
\hline MBO vliegtuigtechniek & - & redelijk & - & enige \\
\hline MBO operationele techniek & - & goed & - & groot \\
\hline MBO elektrotechniek & 1,01 & redelijk & 1,01 & enige \\
\hline MBO grafische techniek & 1,16 & slecht & 1,17 & geen \\
\hline MBO procestechniek & 1,03 & redelijk & 1,03 & enige \\
\hline MBO brood en banket & - & redelijk & - & enige \\
\hline MBO levensmiddelentechniek/vleesverwerking & - & slecht & - & geen \\
\hline MBO vervoer & 1 & goed & 1 & groot \\
\hline MBO dokters-, tandarts- en dierenartsassistent & - & matig & - & vrijwel geen \\
\hline MBO apothekersassistent & - & redelijk & - & enige \\
\hline MBO verpleging en verzorging & 0,98 & goed & 0,98 & groot \\
\hline MBO gezondheidstechniek & - & redelijk & - & enige \\
\hline MBO sociaal-pedagogisch en welzijn & 1,03 & redelijk & 1,03 & enige \\
\hline MBO uiterlijke verzorging & 1,05 & redelijk & 1,06 & vrijwel geen \\
\hline MBO horeca & 1,07 & matig & 1,07 & vrijwel geen \\
\hline MBO bewegingen therapie & - & goed & - & groot \\
\hline MBO administratie en logistiek & 1,01 & redelijk & 1,01 & enige \\
\hline MBO handel & 1 & goed & 1,01 & enige \\
\hline MBO secretariaat & 1,02 & redelijk & 1,02 & enige \\
\hline MBO toerisme en recreatie & - & goed & - & groot \\
\hline MBO facilitaire dienstverlening & 1,01 & redelijk & 1,01 & enige \\
\hline MBO ICT & 1,02 & redelijk & 1,02 & enige \\
\hline MBO geld, bank en belastingen & 0,95 & goed & 0,95 & groot \\
\hline MBO verzekeringswezen & 0,98 & goed & 0,98 & groot \\
\hline MBO openbare orde en veiligheid & 0,98 & goed & 0,98 & groot \\
\hline
\end{tabular}

Bron: ROA 


Tabel 5.1

Verwachte uitbreidingsvraag per bedrijfssector (als percentage van de werkgelegenheid), Overijssel, 2001-2006

\begin{tabular}{lrl}
\hline Bedrijfssector & $\%$ & typering \\
\hline & & \\
Landbouw en visserij & $-6,3$ & laag \\
Voeding & $-2,9$ & gemiddeld \\
Chemie & $-4,7$ & laag \\
Metaal en elektrotechniek & $-10,6$ & erg laag \\
Overige industrie & $-10,1$ & laag \\
Energie & $-3,6$ & gemiddeld \\
Bouw en onroerend goed & $-1,2$ & gemiddeld \\
Handel & 1,3 & gemiddeld \\
Transport en communicatie & 2,3 & hoog \\
Bank en verzekeringswezen & $-1,5$ & gemiddeld \\
Horeca, reparatie en zak. diensten & 8,2 & hoog \\
Kwartaire diensten & 9,3 & erg hoog \\
Overheid en onderwijs & 8,4 & hoog \\
Totaal & 1,9 & -
\end{tabular}

Bron: ROA 
Tabel 5.2

Verwachte uitbreidingsvraag per beroepsgroep (als percentage van de werkgelegenheid), Overijssel, 20012006

\begin{tabular}{lll}
\hline Beroepsgroep & $\% \quad$ typering
\end{tabular}

Leraar basisonderwijs

Docenten exacte, med. en verz. vakken $(2 \mathrm{e}+3 \mathrm{e}$ gr.)

Docenten exacte, med. en verz. vakken (1e gr.)

Docenten landbouw en techniek (2e en $3 e$ gr.)

Docenten landbouw en techniek (1e gr. en WO)

Docenten economisch-admin. vakken (2e en 3 e gr.)

Docenten economisch-admin. vakken (1e gr.)

Docenten talen en expressie

Docenten letteren (1e gr. en WO)

Docenten sociale vakken (2e en $3 \mathrm{e}$ gr.)

Docenten sociale vakken (1e gr.)

Docenten $2 \mathrm{e}$ en $3 \mathrm{e}$ graads zonder specialisatie

Docent 1e graads zonder specialisatie

Onderwijskundig medewerkers

Onderwijskundigen en pedagogen

Rij-instructeurs

Zweminstructeurs

Sportinstructeurs

Tolken, vertalers en schrijvers

Bibliotheekassistenten

Bibliothecarissen

Grafisch ontwerpers

Kunstenaars

Geestelijk verzorgers

Geestelijken

Journalisten

Taalkundigen

Agrarische hulparbeiders

Agrarische arbeiders

Agrarische vakkrachten

Milieuhygiënisten en agrarisch vertegenwoordigers

Landbouwkundigen

Landbouwmachinebestuurders en vissers

Agrarische bedrijfshoofden

Productiemedewerkers

Laboratoriumassistenten

Laboranten

Technisch analisten

Natuurwetenschappers

Conciërges

Hoofden technische dienst

Werktuigbouwkundigen

Bouwvakkers

Aannemers en installateurs

Architecten en bouwkundig projectleiders

Weg- en waterbouwkundigen

Weg- en waterbouwkundige arbeiders

Weg- en waterbouwkundige vakkrachten

Weg- en waterbouwkundig ontwerpers en projectleiders

Metaalarbeiders

Bankwerkers en lassers

Bedrijfshoofden metaalbewerking

Assembleurs

Monteurs

Werktuigbouwk. ontwerpers en hoofden techn. dienst

Elektronicamonteurs

Monteurs en controleurs elektrotechn. producten

Elektromonteurs

Electrotechnisch ontwerpers en bedrijfshoofden

\begin{tabular}{|c|c|}
\hline 1,1 & gemiddeld \\
\hline- & gemiddeld \\
\hline - & hoog \\
\hline & gemiddeld \\
\hline - & gemiddeld \\
\hline- & gemiddeld \\
\hline - & gemiddeld \\
\hline$-7,6$ & erg laag \\
\hline & hoog \\
\hline - & gemiddeld \\
\hline & gemiddeld \\
\hline - & hoog \\
\hline - & erg hoog \\
\hline - & hoog \\
\hline - & erg hoog \\
\hline - & gemiddeld \\
\hline - & gemiddeld \\
\hline- & gemiddeld \\
\hline- & hoog \\
\hline - & gemiddeld \\
\hline - & gemiddeld \\
\hline 50 & hoog \\
\hline$-5,8$ & gemiddeld \\
\hline- & $\begin{array}{l}\text { erg hoog } \\
\text { gemiddeld }\end{array}$ \\
\hline- & hoog \\
\hline 5 & erg hoog \\
\hline- & gemiddeld \\
\hline$-10,7$ & erg laag \\
\hline & erg laag \\
\hline- & hoog \\
\hline 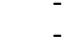 & gemiddeld \\
\hline$-5,3$ & gemiddeld \\
\hline$-2,7$ & gemiddeld \\
\hline & erg laag \\
\hline- & erg laag \\
\hline- & hoog \\
\hline 107 & hoog \\
\hline$-10,7$ & $\begin{array}{l}\text { erg laag } \\
\text { gemiddeld }\end{array}$ \\
\hline 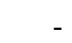 & erg hoog \\
\hline$-15,5$ & erg laag \\
\hline 3,6 & gemiddeld \\
\hline 3,7 & gemiddeld \\
\hline & erg laag \\
\hline & erg laag \\
\hline$-0,6$ & gemiddeld \\
\hline & gemiddeld \\
\hline$-14,8$ & erg laag \\
\hline$-3,2$ & gemiddeld \\
\hline & gemiddeld \\
\hline & erg laag \\
\hline$-13,2$ & erg laag \\
\hline$-4,1$ & gemiddeld \\
\hline- & gemiddeld \\
\hline- & erg laag \\
\hline$-0,9$ & $\begin{array}{l}\text { gemiddeld } \\
\text { erq laaag }\end{array}$ \\
\hline
\end{tabular}


Tabel 5.2 (vervolg)

Verwachte uitbreidingsvraag per beroepsgroep (als percentage van de werkgelegenheid), Overijssel, 20012006

$\begin{array}{lll}\text { Beroepsgroep } & \% \quad \text { typering }\end{array}$

Elektrotechnici

Grafisch productiepersoneel

Grafische vakkrachten

Mechanisch operators

Procesoperators

Procestechnologen

Materiaalkundigen

Confectie-arbeiders

Schoen- en kleermakers

Laders en lossers

Chauffeurs

Schippers en conducteurs

Vliegers, scheepskapiteins en leidinggevenden transport

Stewards

Verpleeghulpen en leerling-verpleegkundigen

Verplegenden en doktersassistenten

Therapeuten en verpleegkundigen

Artsen

Apothekersassistenten en medisch laboranten

Medisch analisten

Apothekers

Afdelingshoofden zorginstelling

Kantoorhulpen, inpakkers en colporteurs

Ondersteunende administratieve hulpkrachten

Bedrijfshoofden

Economen

Productieplanners

Organisatie-adviseurs

Organisatiedeskundigen

Receptionisten en administratieve employés

Boekhouders en secretaresses

Assistent accountants

Accountants

Verzekeringsagenten

Commercieel employés

Commercieel medewerkers

Technisch-commercieel employés

Technisch-bedrijfskundig medewerkers

Juridisch en fiscaal medewerkers

Juridisch, bestuurlijk medewerkers

Juristen

Administratieve transportemployés

Leidinggevenden

Managers

Medisch secretaresses

Programmeurs

Systeemanalisten

Informatici

Technisch systeemanalisten

Act.begeleiders en medew. arbeidsbemiddeling

Sociaal-cultureel werkers

Sociale raadslieden en hoofden personeelszaken

Sociaal-wetenschappelijk medewerkers

Sociaal-wetenschappelijk onderzoekers

Vakkenvullers

Interieurverzorgers

Verkopers

Winkeliers

erg laag

gemiddeld

$-15,1$

0,2

erg laag

gemiddeld

erg laag

- $\quad$ gemiddeld

$-9,9 \quad$ erg laag

- erg laag

$-1,1 \quad$ gemiddeld

$-3,7 \quad$ gemiddeld

- $\quad$ erg laag

- hoog

hoog

erg laag

4,8 gemiddeld

9,4 hoog

8,5 hoog

9,5 hoog

- hoog

- hoog

gemiddeld

erg laag

1,5 gemiddeld

- $\quad$ gemiddeld

25,9 erg hoog

21 erg hoog

- hoog

$-17,7$ erg laag

14,6 hoog

12,6 hoog

41,3 erg hoog

$-9,4$ erg laag

$-2,7 \quad$ gemiddeld

9,9 hoog

- hoog

gemiddeld

$4,5 \quad$ gemiddeld

- gemiddeld

9,1 hoog

- $\quad$ gemiddeld

28,6 erg hoog

25,1 erg hoog

- hoog

hoog

13 hoog

- hoog

gemiddeld

28,2 erg hoog

12,5 hoog

- $\quad$ erg hoog

- $\quad$ gemiddeld

- $\quad$ erg hoog

- gemiddeld

$0 \quad$ gemiddeld

$-3,8 \quad$ gemiddeld

$0,1 \quad$ gemiddeld 
Tabel 5.2 (vervolg)

Verwachte uitbreidingsvraag per beroepsgroep (als percentage van de werkgelegenheid), Overijssel, 20012006

$\begin{array}{lll}\text { Beroepsgroep } & \% \quad \text { typering }\end{array}$

Hulpkrachten horeca en verzorging

Ziekenverzorgenden

Verzorgend personeel

Café- en snackbarhouders

Bedriffshoofden horeca

Bakkers en slagers

Asp. politie-agenten, soldaten en beveiligingshulpen

Agenten, onderofficieren en beveiligingsemployés

Politie-inspecteurs en officieren

Brandweerlieden

$\begin{aligned}-10,9 & \text { erg laag } \\ 21,6 & \text { erg hoog } \\ 1,4 & \text { gemiddeld } \\ - & \text { erg laag } \\ - & \text { gemiddeld } \\ - & \text { erg laag } \\ 1,6 & \text { gemiddeld } \\ -7,9 & \text { erg laag } \\ - & \text { gemiddeld } \\ - & \text { erg laag }\end{aligned}$

Totaal

Bron: ROA 
Tabel 5.3

Verwachte vervangingsvraag per beroepsgroep (als percentage van de werkgelegenheid), Overijssel, 20012006

Beroepsgroep

$\% \quad$ typering

Leraar basisonderwijs

Docenten exacte, med. en verz. vakken $(2 e+3 e$ gr.)

Docenten exacte, med. en verz. vakken (1e gr.)

Docenten landbouw en techniek (2e en $3 e$ gr.)

Docenten landbouw en techniek (1e gr. en WO)

Docenten economisch-admin. vakken (2e en 3e gr.)

Docenten economisch-admin. vakken (1e gr.)

Docenten talen en expressie

Docenten letteren (1e gr. en WO)

Docenten sociale vakken (2e en 3 e gr.)

Docenten sociale vakken (1e gr.)

Docenten 2 e en $3 e$ graads zonder specialisatie

Docent 1e graads zonder specialisatie

Onderwijskundig medewerkers

Onderwijskundigen en pedagogen

Rij-instructeurs

Zweminstructeurs

Sportinstructeurs

Tolken, vertalers en schrijvers

Bibliotheekassistenten

Bibliothecarissen

Grafisch ontwerpers

Kunstenaars

Geestelijk verzorgers

Geestelijken

Journalisten

Taalkundigen

Agrarische hulparbeiders

Agrarische arbeiders

Agrarische vakkrachten

Milieuhygiënisten en agrarisch vertegenwoordigers

Landbouwkundigen

Landbouwmachinebestuurders en vissers

Agrarische bedrijfshoofden

Productiemedewerkers

Laboratoriumassistenten

Laboranten

Technisch analisten

Natuurwetenschappers

Conciërges

Hoofden technische dienst

Werktuigbouwkundigen

Bouwvakkers

Aannemers en installateurs

hoog

- gemiddeld

- $\quad$ erg hoog

erg hoog

- $\quad$ erg hoog

- laag

26,5 hoog

- $\quad$ gemiddeld

hoog

gemiddeld

gemiddeld

- gemiddeld

- $\quad$ gemiddeld

laag

- $\quad$ gemiddeld

- $\quad$ erg laag

- hoog

- gemiddeld

- $\quad$ gemiddeld

- $\quad$ hoog

- $\quad$ gemiddeld

15,8 gemiddeld

- $\quad$ erg hoog

- gemiddeld

- $\quad$ laag

- $\quad$ erg laag

- $\quad$ gemiddeld

17,1 gemiddeld

- laag

- $\quad$ hoog

- $\quad$ laag

- $\quad$ gemiddeld

$42,5 \quad$ erg hoog

15,5 gemiddeld

- hoog

- $\quad$ erg laag

- $\quad$ gemiddeld

erg laag

29,3 erg hoog

- hoog

14,4 gemiddeld

Weg- en waterbouwkundigen

Weg- en waterbouwkundige arbeiders

Weg- en waterbouwkundige vakkrachten

Weg- en waterbouwkundig ontwerpers en projectleiders

Metaalarbeiders

Bankwerkers en lassers

Bedrijfshoofden metaalbewerking

Assembleurs

Monteurs

Werktuigbouwk. ontwerpers en hoofden techn. dienst

Elektronicamonteurs

Monteurs en controleurs elektrotechn. producten

Elektromonteurs

gemiddeld

$29,7 \quad$ hoog

29,7 erg hoog

hoog

21,5 hoog

18,4 gemiddeld

- $\quad$ gemiddeld

- hoog

17,9 gemiddeld

19,5 gemiddeld

- $\quad$ gemiddeld

- $\quad$ hoog

14,5 gemiddeld 
Tabel 5.3 (vervolg)

Verwachte vervangingsvraag per beroepsgroep (als percentage van de werkgelegenheid), Overijssel, 20012006

Beroepsgroep

$\% \quad$ typering

Electrotechnisch ontwerpers en bedrijfshoofden

Elektrotechnici

Grafisch productiepersoneel

Grafische vakkrachten

Mechanisch operators

Procesoperators

Procestechnologen

Materiaalkundigen

Confectie-arbeiders

Schoen- en kleermakers

Laders en lossers

-

Chauffeurs

Schippers en conducteurs

Vliegers, scheepskapiteins en leidinggevenden transport

Stewards

Verpleeghulpen en leerling-verpleegkundigen

Verplegenden en doktersassistenten

Therapeuten en verpleegkundigen

Artsen

Apothekersassistenten en medisch laboranten

Medisch analisten

Apothekers

Afdelingshoofden zorginstelling

Kantoorhulpen, inpakkers en colporteurs

Ondersteunende administratieve hulpkrachten

Bedrijfshoofden

Economen

Productieplanners

Organisatie-adviseurs

Organisatiedeskundigen

Receptionisten en administratieve employés

Boekhouders en secretaresses

Assistent accountants

Accountants

Verzekeringsagenten

Commercieel employés

Commercieel medewerkers

Technisch-commercieel employés

Technisch-bedrijfskundig medewerkers

Juridisch en fiscaal medewerkers

Juridisch, bestuurlijk medewerkers

Juristen

Administratieve transportemployés

Leidinggevenden

- $\quad$ erg laag

- $\quad$ erg hoog

18,2 gemiddeld

27,1 hoog

13,1 gemiddeld

- $\quad$ hoog

- hoog

17,7 gemiddeld

16,2 gemiddeld

21,1 hoog

- gemiddeld

- $\quad$ laag

- $\quad$ erg laag

- $\quad$ laag

$10,8 \quad$ laag

11,2 laag

13,2 gemiddeld

8 laag

- $\quad$ laag

- $\quad$ laag

- $\quad$ erg laag

19,4 gemiddeld

- laag

19,3 gemiddeld

- $\quad$ erg laag

8,8 laag

7,6 laag

- laag

$12,7 \quad$ gemiddeld

11,4 gemiddeld

5,6 erg laag

$9,8 \quad$ laag

10,1 laag

9,6 laag

10,1 laag

- hoog

- laag

31,1 erg hoog

- $\quad$ gemiddeld

$9,1 \quad$ laag

- gemiddeld

15,4 gemiddeld

Managers

Medisch secretaresses

Programmeurs

Systeemanalisten

Informatici

Technisch systeemanalisten

Act.begeleiders en medew. arbeidsbemiddeling

Sociaal-cultureel werkers

16,9

Sociale raadslieden en hoofden personeelszaken

Sociaal-wetenschappelijk medewerkers

Sociaal-wetenschappelijk onderzoekers

Vakkenvullers

Interieurverzorgers

Verkopers

Winkeliers

gemiddeld

- $\quad$ erg hoog

- $\quad$ gemiddeld

- $\quad$ laag

- $\quad$ erg laag

19,2 gemiddeld

11,6 gemiddeld

17,5 gemiddeld 
Tabel 5.3 (vervolg)

Verwachte vervangingsvraag per beroepsgroep (als percentage van de werkgelegenheid), Overijssel, 20012006

Beroepsgroep

$\% \quad$ typering

Hulpkrachten horeca en verzorging

Ziekenverzorgenden

Verzorgend personee

Café- en snackbarhouders

21,5 hoog

Bedrijfshoofden horeca

Bakkers en slagers

Asp. politie-agenten, soldaten en beveiligingshulpen

Agenten, onderofficieren en beveiligingsemployés

Politie-inspecteurs en officieren

22 hoog

14,2 gemiddeld

- $\quad$ erg hoog

- $\quad$ erg hoog

- $\quad$ gemiddeld

Brandweerlieden

$\begin{aligned} 32 & \text { erg hoog } \\ 21,3 & \text { hoog } \\ - & \text { gemiddeld } \\ - & \text { laag }\end{aligned}$

Totaal

15,8

Bron: ROA 
Tabel 5.4

Verwachte baanopeningen per beroepsgroep (als percentage van de werkgelegenheid), Overijssel, 2001-2006

Beroepsgroep

Leraar basisonderwijs

Docenten exacte, med. en verz. vakken $(2 \mathrm{e}+3 \mathrm{e}$ gr.)

Docenten exacte, med. en verz. vakken (1e gr.)

Docenten landbouw en techniek (2e en $3 e$ gr.)

Docenten landbouw en techniek (1e gr. en WO)

Docenten economisch-admin. vakken (2e en 3 e gr.)

Docenten economisch-admin. vakken (1e gr.)

Docenten talen en expressie

Docenten letteren (1e gr. en WO)

Docenten sociale vakken (2e en $3 e$ gr.)

Docenten sociale vakken (1e gr.)

Docenten $2 \mathrm{e}$ en $3 \mathrm{e}$ graads zonder specialisatie

Docent $1 \mathrm{e}$ graads zonder specialisatie

Onderwijskundig medewerkers

Onderwijskundigen en pedagogen

Rij-instructeurs

Zweminstructeurs

Sportinstructeurs

Tolken, vertalers en schrijvers

Bibliotheekassistenten

Bibliothecarissen

Grafisch ontwerpers

Kunstenaars

Geestelijk verzorgers

Geestelijken

Journalisten

Taalkundigen

Agrarische hulparbeiders

Agrarische arbeiders

Agrarische vakkrachten

Milieuhygiënisten en agrarisch vertegenwoordigers

Landbouwkundigen

Landbouwmachinebestuurders en vissers

Agrarische bedrijfshoofden

Productiemedewerkers

Laboratoriumassistenten

Laboranten

Technisch analisten

Natuurwetenschappers

Conciërges

Hoofden technische dienst

Werktuigbouwkundigen

Bouwvakkers

Aannemers en installateurs

Architecten en bouwkundig projectleiders

Weg- en waterbouwkundigen

Weg- en waterbouwkundige arbeiders

Weg- en waterbouwkundige vakkrachten

Weg- en waterbouwkundig ontwerpers en projectleiders

Metaalarbeiders

Bankwerkers en lassers

Bedrijfshoofden metaalbewerking

Assembleurs

Monteurs

Werktuigbouwk. ontwerpers en hoofden techn. dienst

Elektronicamonteurs

Monteurs en controleurs elektrotechn. producten

Elektromonteurs

Electrotechnisch ontwerpers en bedrijfshoofden

Elektrotechnici

$\% \quad$ typering

26,5

- $\quad$ hoog

- hoog

- $\quad$ erg hoog

- $\quad$ erg hoog

- $\quad$ erg hoog

- $\quad$ laag

26,5 hoog

- hoog

- $\quad$ gemiddeld

- $\quad$ gemiddeld

- $\quad$ hoog

- hoog

- hoog

- $\quad$ erg hoog

- gemiddeld

- $\quad$ erg laag

- $\quad$ gemiddeld

- $\quad$ gemiddeld

- $\quad$ laag

- hoog

- hoog

15,8 gemiddeld

- $\quad$ erg hoog

- $\quad$ gemiddeld

- hoog

- hoog

- $\quad$ gemiddeld

17,1 gemiddeld

- laag

- hoog

- $\quad$ laag

- $\quad$ gemiddeld

42,5 erg hoog

15,5 laag

- hoog

- $\quad$ erg laag

- $\quad$ gemiddeld

- $\quad$ gemiddeld

29,3 hoog

- gemiddeld

- $\quad$ erg hoog

23,1 gemiddeld

23,1 gemiddeld

18 gemiddeld

- $\quad$ gemiddeld

- $\quad$ gemiddeld

29,7 hoog

- hoog

21,5 gemiddeld

18,4 gemiddeld

- $\quad$ gemiddeld

- hoog

17,9 gemiddeld

$19,5 \quad$ gemiddeld

- $\quad$ gemiddeld

- gemiddeld

14,5 laag

- $\quad$ laag

- laag 
Tabel 5.4 (vervolg)

Verwachte baanopeningen per beroepsgroep (als percentage van de werkgelegenheid), Overijssel, 2001-2006

Grafisch productiepersoneel

Grafische vakkrachten

- hoog

Mechanisch operators

18,2

Procesoperators

Procestechnologen

Materiaalkundigen

Confectie-arbeiders

Schoen- en kleermakers

Laders en lossers

27,1 hoog

13,3 laag

- $\quad$ gemiddeld

- $\quad$ gemiddeld

17,7 gemiddeld

Chauffeurs

Schippers en conducteurs

Vliegers, scheepskapiteins en leidinggevenden transport

Stewards

Verpleeghulpen en leerling-verpleegkundigen

Verplegenden en doktersassistenten

Therapeuten en verpleegkundigen

Artsen

Apothekersassistenten en medisch laboranten

Medisch analisten

Apothekers

Afdelingshoofden zorginstelling

Kantoorhulpen, inpakkers en colporteurs

Ondersteunende administratieve hulpkrachten

Bedrijfshoofden

Economen

Productieplanners

Organisatie-adviseurs

Organisatiedeskundigen

Receptionisten en administratieve employés

Boekhouders en secretaresses

Assistent accountants

Accountants

Verzekeringsagenten

Commercieel employés

Commercieel medewerkers

Technisch-commercieel employés

Technisch-bedrijfskundig medewerkers

Juridisch en fiscaal medewerkers

Juridisch, bestuurlijk medewerkers

Juristen

Administratieve transportemployés

Leidinggevenden

Managers

Medisch secretaresses

Programmeurs

Systeemanalisten

Informatici

Technisch systeemanalisten

Act.begeleiders en medew. arbeidsbemiddeling

Sociaal-cultureel werkers

Sociale raadslieden en hoofden personeelszaken

Sociaal-wetenschappelijk medewerkers

Sociaal-wetenschappelijk onderzoekers

Vakkenvullers

Interieurverzorgers

Verkopers

Winkeliers

Hulpkrachten horeca en verzorging

- gemiddeld

16,2 gemiddeld

21,1 gemiddeld

- laag

- $\quad$ gemiddeld

- laag

- laag

$15,6 \quad$ laag

20,6 gemiddeld

21,8 gemiddeld

17,5 gemiddeld

- $\quad$ gemiddeld

- $\quad$ gemiddeld

- $\quad$ laag

23,2 gemiddeld

- laag

20,9 gemiddeld

- laag

34,7 hoog

28,7 hoog

- $\quad$ gemiddeld

12,7 laag

26 gemiddeld

18,2 gemiddeld

51,1 erg hoog

10,1 laag

$9,6 \quad$ laag

20,1 gemiddeld

- hoog

- laag

35,6 hoog

- gemiddeld

18,3 gemiddeld

- laag

44,1 erg hoog

43,8 erg hoog

- $\quad$ gemiddeld

20,3 gemiddeld

18,7 gemiddeld

- hoog

- laag

$45,1 \quad$ erg hoog

25,8 gemiddeld

- $\quad$ erg hoog

- gemiddeld

- hoog

- laag

19,3 gemiddeld

11,6 laag

17,6 gemiddeld

21,5 gemiddeld

43,6 erg hoog 
Tabel 5.4 (vervolg)

Verwachte baanopeningen per beroepsgroep (als percentage van de werkgelegenheid), Overijssel, 2001-2006

Beroepsgroep

Verzorgend personeel

Café- en snackbarhouders

Bedrijfshoofden horeca

Bakkers en slagers

Asp. politie-agenten, soldaten en beveiligingshulpen

Agenten, onderofficieren en beveiligingsemployés

Politie-inspecteurs en officieren

Brandweerlieden

Totaal

Bron: ROA
$\% \quad$ typering

15,6 laag

- $\quad$ erg hoog

- hoog

- laag

33,6 hoog

21,3 gemiddeld

- laag

- laag 
Tabel 5.5

Indicator Toekomstige knelpunten in de personeelsvoorziening per Beroep (ITKB) per beroepsgroep, Overijssel, 2001-2006 (alleen elementaire, lagere en middelbare beroepen)

\begin{tabular}{|c|c|c|}
\hline Beroepsgroep & ITKB & typering \\
\hline Rij-instructeurs & - & enige \\
\hline Zweminstructeurs & - & geen \\
\hline Sportinstructeurs & - & enige \\
\hline Bibliotheekassistenten & - & geen \\
\hline Grafisch ontwerpers & - & enige \\
\hline Agrarische hulparbeiders & - & vrijwel geen \\
\hline Agrarische arbeiders & 1,22 & geen \\
\hline Agrarische vakkrachten & - & geen \\
\hline Landbouwmachinebestuurders en vissers & - & geen \\
\hline Agrarische bedrijfshoofden & 0,92 & groot \\
\hline Productiemedewerkers & 1,20 & geen \\
\hline Laboratoriumassistenten & - & vrijwel geen \\
\hline Laboranten & - & vrijwel geen \\
\hline Conciërges & 1,05 & enige \\
\hline Hoofden technische dienst & - & enige \\
\hline Bouwvakkers & 1,15 & vrijwel geen \\
\hline Aannemers en installateurs & 1,01 & enige \\
\hline Weg- en waterbouwkundige arbeiders & - & geen \\
\hline Weg- en waterbouwkundige vakkrachten & 0,97 & groot \\
\hline Metaalarbeiders & 1,17 & geen \\
\hline Bankwerkers en lassers & 1,08 & vrijwel geen \\
\hline Assembleurs & - & vrijwel geen \\
\hline Monteurs & 1,19 & geen \\
\hline Elektronicamonteurs & - & enige \\
\hline Monteurs en controleurs elektrotechn. producten & - & geen \\
\hline Elektromonteurs & 1,10 & vrijwel geen \\
\hline Grafisch productiepersoneel & - & geen \\
\hline Grafische vakkrachten & 1,06 & vrijwel geen \\
\hline Mechanisch operators & 1,12 & vrijwel geen \\
\hline Procesoperators & 0,88 & groot \\
\hline Confectie-arbeiders & 1,17 & geen \\
\hline Schoen- en kleermakers & - & geen \\
\hline Laders en lossers & 1,17 & geen \\
\hline Chauffeurs & 1,13 & vrijwel geen \\
\hline Schippers en conducteurs & - & geen \\
\hline Stewards & - & vrijwel geen \\
\hline Verpleeghulpen en leerling-verpleegkundigen & - & geen \\
\hline Verplegenden en doktersassistenten & 1,05 & enige \\
\hline Apothekersassistenten en medisch laboranten & 1,03 & enige \\
\hline Kantoorhulpen, inpakkers en colporteurs & 1,09 & vrijwel geen \\
\hline Ondersteunende administratieve hulpkrachten & - & geen \\
\hline Productieplanners & 0,92 & groot \\
\hline Receptionisten en administratieve employés & 1,33 & geen \\
\hline Boekhouders en secretaresses & 0,98 & groot \\
\hline Verzekeringsagenten & 1,25 & geen \\
\hline Commercieel employés & 1,16 & geen \\
\hline Technisch-commercieel employés & - & groot \\
\hline Juridisch en fiscaal medewerkers & 0,87 & groot \\
\hline Administratieve transportemployés & - & geen \\
\hline Medisch secretaresses & - & groot \\
\hline Programmeurs & 1,03 & enige \\
\hline Act.begeleiders en medew. arbeidsbemiddeling & 0,96 & groot \\
\hline Vakkenvullers & - & geen \\
\hline Interieurverzorgers & 1,13 & vrijwel geen \\
\hline
\end{tabular}


Tabel 5.5 (vervolg)

Indicator Toekomstige Knelpunten in de personeelsvoorziening per Beroep (ITKB) per beroepsgroep, Overijssel, 2001-2006 (alleen elementaire, lagere en middelbare beroepen)

\begin{tabular}{lll} 
Beroepsgroep & ITKB & typering \\
\hline Verkopers & & \\
Winkeliers & 1,16 & geen \\
Hulpkrachten horeca en verzorging & 1,07 & vrijwel geen \\
Ziekenverzorgenden & 1,32 & geen \\
Verzorgend personeel & 0,84 & zeer groot \\
Café- en snackbarhouders & 1,21 & geen \\
Bedrijfshoofden horeca & - & groot \\
Bakkers en slagers & - & enige \\
Asp. politie-agenten, soldaten en beveiligingshulpen & - & geen \\
Agenten, onderofficieren en beveiligingsemployés & 1,01 & enige \\
Brandweerlieden & 1,03 & enige \\
& - & groot
\end{tabular}

Bron: ROA 
Tabel 5.6

Verwachte uitbreidingsvraag per opleidingstype (als percentage van de werkgelegenheid), Overijssel, 20012006

\begin{tabular}{|c|c|c|}
\hline Opleidingstype & $\%$ & typering \\
\hline Basisonderwijs & $-24,9$ & erg laag \\
\hline VMBO theorie & $-4,7$ & laag \\
\hline VMBO landbouw en natuurlijke omgeving & $-33,8$ & erg laag \\
\hline VMBO bouwtechniek & $-11,7$ & laag \\
\hline VMBO installatietechniek & - & laag \\
\hline VMBO mechanische techniek & $-24,2$ & erg laag \\
\hline VMBO fijnmechanische techniek & - & erg laag \\
\hline VMBO motorvoertuigentechniek & - & erg laag \\
\hline VMBO elektrotechniek & $-10,8$ & laag \\
\hline VMBO grafische techniek & - & erg laag \\
\hline VMBO brood en banket & - & erg laag \\
\hline VMBO horeca en levensmiddelentechniek & - & erg laag \\
\hline VMBO vervoer & $-18,7$ & erg laag \\
\hline VMBO administratie, handel en textiel & $-25,2$ & erg laag \\
\hline VMBO verzorging & $-12,8$ & laag \\
\hline VMBO beveiliging & - & hoog \\
\hline HAVO/VWO & 11,5 & gemiddeld \\
\hline MBO voeding, natuur en milieu & 10,7 & gemiddeld \\
\hline MBO groene ruimte & - & hoog \\
\hline MBO bouw & 11,4 & gemiddeld \\
\hline MBO grond-, weg- en waterbouw & - & gemiddeld \\
\hline MBO installatietechniek & - & gemiddeld \\
\hline MBO werktuigbouw en mechanische techniek & $-3,6$ & laag \\
\hline MBO fijnmechanische techniek en laboratorium & 5,9 & gemiddeld \\
\hline MBO motorvoertuigentechniek en tweewielers & 9,2 & gemiddeld \\
\hline MBO vliegtuigtechniek & - & laag \\
\hline MBO operationele techniek & - & gemiddeld \\
\hline MBO elektrotechniek & 4,3 & gemiddeld \\
\hline MBO grafische techniek & $-10,9$ & laag \\
\hline MBO procestechniek & 16,3 & hoog \\
\hline MBO brood en banket & - & laag \\
\hline MBO levensmiddelentechniek/vleesverwerking & - & gemiddeld \\
\hline MBO vervoer & 7,9 & gemiddeld \\
\hline MBO dokters-, tandarts- en dierenartsassistent & - & hoog \\
\hline MBO apothekersassistent & - & hoog \\
\hline $\mathrm{MBO}$ verpleging en verzorging & 0,8 & laag \\
\hline MBO gezondheidstechniek & - & hoog \\
\hline MBO sociaal-pedagogisch en welzijn & 18,5 & hoog \\
\hline MBO uiterlijke verzorging & 6,4 & gemiddeld \\
\hline MBO horeca & 12,3 & gemiddeld \\
\hline MBO bewegingen therapie & - & gemiddeld \\
\hline MBO administratie en logistiek & 6,8 & gemiddeld \\
\hline MBO handel & $-4,5$ & laag \\
\hline MBO secretariaat & 13,4 & gemiddeld \\
\hline MBO toerisme en recreatie & - & hoog \\
\hline MBO facilitaire dienstverlening & 4,9 & gemiddeld \\
\hline MBO ICT & 6,8 & gemiddeld \\
\hline MBO geld, bank en belastingen & $-14,2$ & erg laag \\
\hline MBO verzekeringswezen & & laag \\
\hline MBO openbare orde en veiligheid & 0,6 & laag \\
\hline HBO lerarenopleiding basisonderwijs & 10,6 & gemiddeld \\
\hline HBO lerarenopleiding talen & - & laag \\
\hline HBO lerarenopleiding natuur en techniek & 3,1 & gemiddeld \\
\hline HBO lerarenopleiding economie en maatschappij & 21,2 & hoog \\
\hline
\end{tabular}


Tabel 5.6 (vervolg)

Verwachte uitbreidingsvraag per opleidingstype (als percentage van de werkgelegenheid), Overijssel, 20012006

\begin{tabular}{|c|c|c|}
\hline Opleidingstype & $\%$ & typering \\
\hline HBO lerarenopleiding lichamelijke opvoeding & - & laag \\
\hline HBO lerarenopleiding medisch en verzorging & - & gemiddeld \\
\hline HBO lerarenopleiding expressie & - & laag \\
\hline HBO tolk en vertaler & - & gemiddeld \\
\hline HBO landbouw en veeteelt & - & erg hoog \\
\hline HBO milieukunde en levensmiddelentechnologie & - & gemiddeld \\
\hline HBO laboratorium & $-1,1$ & laag \\
\hline HBO bouwkunde & - & gemiddeld \\
\hline HBO civiele techniek & - & laag \\
\hline HBO werktuigbouwkunde & 4,3 & gemiddeld \\
\hline HBO elektrotechniek & 5,1 & gemiddeld \\
\hline HBO informatica & 19,2 & hoog \\
\hline HBO chemische technologie & - & gemiddeld \\
\hline HBO vervoer en logistiek & - & gemiddeld \\
\hline HBO verpleegkunde & 22,5 & hoog \\
\hline HBO (fysio)therapie & 27,3 & hoog \\
\hline HBO voeding & - & hoog \\
\hline $\mathrm{HBO}$ radiologie & - & hoog \\
\hline HBO accountancy en bedrijfseconomie & 11,5 & gemiddeld \\
\hline HBO commerciële economie & 17,4 & hoog \\
\hline HBO toerisme en recreatie & & gemiddeld \\
\hline HBO recht en bestuur & 23,6 & hoog \\
\hline HBO secretariaat & 9,8 & gemiddeld \\
\hline HBO bedrijfskunde & 18,4 & hoog \\
\hline HBO communicatie en journalistiek & - & erg hoog \\
\hline HBO maatschappelijk werk en hulpverlening & 11,1 & gemiddeld \\
\hline HBO personeelswerk & & laag \\
\hline HBO bibliotheek en documentatie & - & gemiddeld \\
\hline HBO uitvoerende en beeldende kunsten & 10,9 & gemiddeld \\
\hline HBO openbare orde en veiligheid & - & gemiddeld \\
\hline WO letteren & 19 & hoog \\
\hline WO theologie & - & gemiddeld \\
\hline WO landbouw en milieukunde & - & gemiddeld \\
\hline WO wiskunde en natuurwetenschappen & 6,3 & gemiddeld \\
\hline WO bouwkunde & - & hoog \\
\hline WO civiele techniek & - & hoog \\
\hline WO werktuigbouwkunde & - & gemiddeld \\
\hline WO elektrotechniek & - & gemiddeld \\
\hline WO informatica en bestuurlijke informatiekunde & - & erg hoog \\
\hline WO (dier)geneeskunde & 3,1 & gemiddeld \\
\hline WO tandheelkunde & - & gemiddeld \\
\hline WO farmacie en medische biologie & - & gemiddeld \\
\hline WO econom(etr)ie & 30,6 & erg hoog \\
\hline WO bedrijfskunde & 33,2 & erg hoog \\
\hline WO accountancy en belastingen & - & erg hoog \\
\hline WO rechten en bestuurskunde & 11,2 & gemiddeld \\
\hline WO sociale wetenschappen & 22 & hoog \\
\hline WO kunstwetenschappen & - & hoog \\
\hline Totaal & 3,2 & - \\
\hline
\end{tabular}

Bron: ROA 
Tabel 5.7

Verwachte vervangingsvraag per opleidingstype (als percentage van de werkgelegenheid), Overijssel, 20012006

\begin{tabular}{|c|c|c|}
\hline Opleidingstype & $\%$ & typering \\
\hline Basisonderwijs & 40,1 & erg hoog \\
\hline VMBO theorie & 23,7 & hoog \\
\hline VMBO landbouw en natuurlijke omgeving & 29,6 & hoog \\
\hline VMBO bouwtechniek & 23,7 & hoog \\
\hline VMBO installatietechniek & - & gemiddeld \\
\hline VMBO mechanische techniek & 32,3 & erg hoog \\
\hline VMBO fijnmechanische techniek & - & laag \\
\hline VMBO motorvoertuigentechniek & - & erg hoog \\
\hline VMBO elektrotechniek & 26,1 & hoog \\
\hline VMBO grafische techniek & - & erg hoog \\
\hline VMBO brood en banket & - & hoog \\
\hline VMBO horeca en levensmiddelentechniek & - & hoog \\
\hline VMBO vervoer & 30,3 & erg hoog \\
\hline VMBO administratie, handel en textiel & 30,9 & erg hoog \\
\hline VMBO verzorging & 25,6 & hoog \\
\hline VMBO beveiliging & - & hoog \\
\hline HAVO/VWO & 28,2 & hoog \\
\hline MBO voeding, natuur en milieu & 19 & gemiddeld \\
\hline MBO groene ruimte & - & gemiddeld \\
\hline MBO bouw & 24,4 & hoog \\
\hline MBO grond-, weg- en waterbouw & - & gemiddeld \\
\hline MBO installatietechniek & - & gemiddeld \\
\hline MBO werktuigbouw en mechanische techniek & 26,6 & hoog \\
\hline MBO fijnmechanische techniek en laboratorium & 18,7 & gemiddeld \\
\hline MBO motorvoertuigentechniek en tweewielers & 23 & hoog \\
\hline MBO vliegtuigtechniek & - & laag \\
\hline MBO operationele techniek & - & gemiddeld \\
\hline MBO elektrotechniek & 22 & gemiddeld \\
\hline MBO grafische techniek & 22,5 & hoog \\
\hline MBO procestechniek & 9,8 & laag \\
\hline MBO brood en banket & - & gemiddeld \\
\hline MBO levensmiddelentechniek/vleesverwerking & - & gemiddeld \\
\hline MBO vervoer & 22,3 & gemiddeld \\
\hline MBO dokters-, tandarts- en dierenartsassistent & - & gemiddeld \\
\hline MBO apothekersassistent & - & gemiddeld \\
\hline MBO verpleging en verzorging & 20,9 & gemiddeld \\
\hline MBO gezondheidstechniek & - & gemiddeld \\
\hline MBO sociaal-pedagogisch en welzijn & 20,9 & gemiddeld \\
\hline MBO uiterlijke verzorging & 11,9 & laag \\
\hline MBO horeca & 13,6 & gemiddeld \\
\hline MBO bewegingen therapie & - & gemiddeld \\
\hline MBO administratie en logistiek & 20,3 & gemiddeld \\
\hline MBO handel & 17,7 & gemiddeld \\
\hline MBO secretariaat & 13,5 & gemiddeld \\
\hline MBO toerisme en recreatie & - & erg hoog \\
\hline MBO facilitaire dienstverlening & 31,7 & erg hoog \\
\hline MBO ICT & 15,7 & gemiddeld \\
\hline MBO geld, bank en belastingen & 27,4 & hoog \\
\hline MBO verzekeringswezen & - & hoog \\
\hline MBO openbare orde en veiligheid & 22,3 & gemiddeld \\
\hline HBO lerarenopleiding basisonderwijs & 20,3 & gemiddeld \\
\hline HBO lerarenopleiding talen & - & hoog \\
\hline HBO lerarenopleiding natuur en techniek & 17 & gemiddeld \\
\hline HBO lerarenopleiding economie en maatschappij & 31,8 & erg hoog \\
\hline
\end{tabular}


Tabel 5.7 (vervolg)

Verwachte vervangingsvraag per opleidingstype (als percentage van de werkgelegenheid), Overijssel, 20012006

\begin{tabular}{lll}
\hline Opleidingstype & $\% \quad$ typering
\end{tabular}

HBO lerarenopleiding lichamelijke opvoeding $\mathrm{HBO}$ lerarenopleiding medisch en verzorging HBO lerarenopleiding expressie

$\mathrm{HBO}$ tolk en vertaler

HBO landbouw en veeteelt

HBO milieukunde en levensmiddelentechnologie

HBO laboratorium

HBO bouwkunde

HBO civiele techniek

HBO werktuigbouwkunde

HBO elektrotechniek

HBO informatica

HBO chemische technologie

HBO vervoer en logistiek

HBO verpleegkunde

HBO (fysio)therapie

$\mathrm{HBO}$ voeding

$\mathrm{HBO}$ radiologie

HBO accountancy en bedrijfseconomie

HBO commerciële economie

$\mathrm{HBO}$ toerisme en recreatie

HBO recht en bestuur

$\mathrm{HBO}$ secretariaat

HBO bedrijfskunde

HBO communicatie en journalistiek

HBO maatschappelijk werk en hulpverlening

HBO personeelswerk

HBO bibliotheek en documentatie

HBO uitvoerende en beeldende kunsten

HBO openbare orde en veiligheid

WO letteren

WO theologie

WO landbouw en milieukunde

WO wiskunde en natuurwetenschappen

WO bouwkunde

WO civiele techniek

WO werktuigbouwkunde

WO elektrotechniek

WO informatica en bestuurlijke informatiekunde

WO (dier)geneeskunde

WO tandheelkunde

WO farmacie en medische biologie

WO econom(etr)ie

WO bedrijfskunde

WO accountancy en belastingen

WO rechten en bestuurskunde

WO sociale wetenschappen

WO kunstwetenschappen

hoog

hoog

erg hoog

erg laag

laag

- $\quad$ gemiddeld

15,7 gemiddeld

- $\quad$ gemiddeld

gemiddeld

19,4 gemiddeld

23,1 hoog

$11,5 \quad$ laag

- hoog

- laag

$12,8 \quad$ gemiddeld

22,6 hoog

- $\quad$ erg laag

- laag

$12,9 \quad$ gemiddeld

$9,4 \quad$ laag

- erg laag

12,6 gemiddeld

$20,1 \quad$ gemiddeld

$10,4 \quad$ laag

- laag

23 hoog

- $\quad$ gemiddeld

- laag

20,5 gemiddeld

- $\quad$ laag

5 erg laag

- $\quad$ gemiddeld

laag

12,3 gemiddeld

- $\quad$ gemiddeld

- $\quad$ laag

- $\quad$ gemiddeld

- $\quad$ laag

- $\quad$ erg laag

0,8 laag

- $\quad$ gemiddeld

- $\quad$ erg laag

$7,1 \quad$ laag

5,6 laag

- laag

6,3 laag

12,6 gemiddeld

- $\quad$ erg laag

Totaal

21,4

Bron: ROA 
Tabel 5.8

Verwachte baanopeningen per opleidingstype (als percentage van de werkgelegenheid), Overijssel, 2001-2006

\begin{tabular}{|c|c|c|}
\hline Opleidingstype & $\%$ & typering \\
\hline Basisonderwijs & 40,1 & hoog \\
\hline VMBO theorie & 23,7 & laag \\
\hline VMBO landbouw en natuurlijke omgeving & 29,6 & gemiddeld \\
\hline VMBO bouwtechniek & 23,7 & gemiddeld \\
\hline VMBO installatietechniek & - & laag \\
\hline VMBO mechanische techniek & 32,3 & hoog \\
\hline VMBO fijnmechanische techniek & - & erg laag \\
\hline VMBO motorvoertuigentechniek & - & hoog \\
\hline VMBO elektrotechniek & 26,1 & gemiddeld \\
\hline VMBO grafische techniek & - & hoog \\
\hline VMBO brood en banket & - & gemiddeld \\
\hline VMBO horeca en levensmiddelentechniek & - & gemiddeld \\
\hline VMBO vervoer & 30,3 & gemiddeld \\
\hline VMBO administratie, handel en textiel & 30,9 & gemiddeld \\
\hline VMBO verzorging & 25,6 & gemiddeld \\
\hline VMBO beveiliging & - & erg hoog \\
\hline HAVO/VWO & 39,6 & hoog \\
\hline MBO voeding, natuur en milieu & 29,7 & gemiddeld \\
\hline MBO groene ruimte & - & hoog \\
\hline MBO bouw & 35,8 & hoog \\
\hline MBO grond-, weg- en waterbouw & - & gemiddeld \\
\hline MBO installatietechniek & - & gemiddeld \\
\hline MBO werktuigbouw en mechanische techniek & 26,6 & gemiddeld \\
\hline MBO fijnmechanische techniek en laboratorium & 24,8 & gemiddeld \\
\hline MBO motorvoertuigentechniek en tweewielers & 32,2 & gemiddeld \\
\hline MBO vliegtuigtechniek & - & erg laag \\
\hline MBO operationele techniek & - & gemiddeld \\
\hline MBO elektrotechniek & 26,3 & gemiddeld \\
\hline MBO grafische techniek & 22,5 & laag \\
\hline MBO procestechniek & 26,1 & gemiddeld \\
\hline MBO brood en banket & - & laag \\
\hline MBO levensmiddelentechniek/vleesverwerking & - & laag \\
\hline MBO vervoer & 30,1 & gemiddeld \\
\hline MBO dokters-, tandarts- en dierenartsassistent & - & gemiddeld \\
\hline MBO apothekersassistent & - & hoog \\
\hline $\mathrm{MBO}$ verpleging en verzorging & 26,1 & gemiddeld \\
\hline MBO gezondheidstechniek & & hoog \\
\hline MBO sociaal-pedagogisch en welzijn & 39,4 & hoog \\
\hline MBO uiterlijke verzorging & 18,3 & laag \\
\hline MBO horeca & 25,9 & gemiddeld \\
\hline MBO bewegingen therapie & - & gemiddeld \\
\hline MBO administratie en logistiek & 27,1 & gemiddeld \\
\hline MBO handel & 17,7 & laag \\
\hline MBO secretariaat & 26,9 & gemiddeld \\
\hline MBO toerisme en recreatie & - & erg hoog \\
\hline MBO facilitaire dienstverlening & 36,6 & hoog \\
\hline MBO ICT & 22,5 & laag \\
\hline MBO geld, bank en belastingen & 27,4 & gemiddeld \\
\hline MBO verzekeringswezen & - & gemiddeld \\
\hline MBO openbare orde en veiligheid & 22,9 & laag \\
\hline HBO lerarenopleiding basisonderwijs & 30,9 & gemiddeld \\
\hline HBO lerarenopleiding talen & & gemiddeld \\
\hline HBO lerarenopleiding natuur en techniek & 20,1 & laag \\
\hline HBO lerarenopleiding economie en maatschappij & 53 & erg hoog \\
\hline HBO lerarenopleiding lichamelijke opvoeding & - & gemiddeld \\
\hline
\end{tabular}


Tabel 5.8 (vervolg)

Verwachte baanopeningen per opleidingstype (als percentage van de werkgelegenheid), Overijssel, 2001-2006

Opleidingstype

$\% \quad$ typering

HBO lerarenopleiding medisch en verzorging

HBO lerarenopleiding expressie

HBO tolk en vertaler

HBO landbouw en veeteelt

HBO milieukunde en levensmiddelentechnologie

HBO laboratorium

HBO bouwkunde

HBO civiele techniek

HBO werktuigbouwkunde

HBO elektrotechniek

- $\quad$ gemiddeld

hoog

HBO informatica

$\mathrm{HBO}$ chemische technologie

HBO vervoer en logistiek

$\mathrm{HBO}$ verpleegkunde

HBO (fysio)therapie

$\mathrm{HBO}$ voeding

$\mathrm{HBO}$ radiologie

HBO accountancy en bedrijfseconomie

HBO commerciële economie

$\mathrm{HBO}$ toerisme en recreatie

HBO recht en bestuur

- $\quad$ erg laag

- hoog

HBO secretariaat

- $\quad$ erg laag

HBO bedrijfskunde

HBO communicatie en journalistiek

HBO maatschappelijk werk en hulpverlening

HBO personeelswerk

HBO bibliotheek en documentatie

HBO uitvoerende en beeldende kunsten

HBO openbare orde en veiligheid

15,7 laag

- $\quad$ gemiddeld

gemiddeld

28,3 gemiddeld

30,7 gemiddeld

- hoog

- $\quad$ erg laag

35,3 hoog

$49,9 \quad$ erg hoog

- laag

gemiddeld

$24,4 \quad$ gemiddeld

26,8 gemiddeld

- erg laag

36,2 hoog

29,9 gemiddeld

28,8 gemiddeld

- hoog

$34,1 \quad$ hoog

- laag

laag

$31,4 \quad$ gemiddeld

- $\quad$ laag

WO letteren

WO theologie

WO landbouw en milieukunde

WO wiskunde en natuurwetenschappen

WO bouwkunde

WO civiele techniek

WO werktuigbouwkunde

WO elektrotechniek

WO informatica en bestuurlijke informatiekunde

WO (dier)geneeskunde

WO tandheelkunde

WO farmacie en medische biologie

WO econom(etr)ie

WO bedrijfskunde

WO accountancy en belastingen

WO rechten en bestuurskunde

24 gemiddeld

- gemiddeld

- laag

18,7 laag

- $\quad$ gemiddeld

- $\quad$ gemiddeld

- $\quad$ laag

- erg laag

- $\quad$ erg hoog

13,9 erg laag

- $\quad$ gemiddeld

erg laag

37,7 hoog

38,8 hoog

erg hoog

WO kunstwetenschappen

34,6 hoog

- laag

Totaal

29,5

Bron: ROA 
Tabel 5.9

Verwachte arbeidsmarktinstroom van schoolverlaters per opleidingstype (als percentage van de werkgelegenheid), Overijssel, 2001-2006 (alleen lagere en middelbare opleidingen)

\begin{tabular}{|c|c|c|}
\hline Opleidingstype & $\%$ & typering \\
\hline Basisonderwijs & 26,9 & gemiddeld \\
\hline VMBO theorie & 21,6 & gemiddeld \\
\hline VMBO landbouw en natuurlijke omgeving & 35,7 & hoog \\
\hline VMBO bouwtechniek & 28,4 & hoog \\
\hline VMBO installatietechniek & 2, & gemiddeld \\
\hline VMBO mechanische techniek & 21,6 & gemiddeld \\
\hline VMBO fijnmechanische techniek & - & erg laag \\
\hline VMBO motorvoertuigentechniek & - & hoog \\
\hline VMBO elektrotechniek & 34,3 & hoog \\
\hline VMBO grafische techniek & - & laag \\
\hline VMBO brood en banket & - & gemiddeld \\
\hline VMBO horeca en levensmiddelentechniek & - & hoog \\
\hline VMBO vervoer & 8,2 & laag \\
\hline VMBO administratie, handel en textiel & 52 & erg hoog \\
\hline VMBO verzorging & 29,7 & hoog \\
\hline VMBO beveiliging & - & erg hoog \\
\hline HAVO/VWO & 44,4 & erg hoog \\
\hline MBO voeding, natuur en milieu & 29,8 & hoog \\
\hline MBO groene ruimte & 20,0 & erg hoog \\
\hline MBO bouw & 42,8 & erg hoog \\
\hline MBO grond-, weg- en waterbouw & - & hoog \\
\hline MBO installatietechniek & - & gemiddeld \\
\hline MBO werktuigbouw en mechanische techniek & 18,5 & gemiddeld \\
\hline MBO fijnmechanische techniek en laboratorium & 10,7 & gemiddeld \\
\hline MBO motorvoertuigentechniek en tweewielers & 31,8 & hoog \\
\hline MBO vliegtuigtechniek & - & laag \\
\hline MBO operationele techniek & - & gemiddeld \\
\hline MBO elektrotechniek & 29,6 & hoog \\
\hline MBO grafische techniek & 27,1 & hoog \\
\hline MBO procestechniek & 13,3 & gemiddeld \\
\hline MBO brood en banket & - & gemiddeld \\
\hline MBO levensmiddelentechniek/vleesverwerking & - & erg hoog \\
\hline MBO vervoer & 18,2 & gemiddeld \\
\hline MBO dokters-, tandarts- en dierenartsassistent & - & hoog \\
\hline MBO apothekersassistent & - & gemiddeld \\
\hline MBO verpleging en verzorging & 24,6 & gemiddeld \\
\hline MBO gezondheidstechniek & - & laag \\
\hline MBO sociaal-pedagogisch en welziin & 59,4 & erg hoog \\
\hline MBO uiterlijke verzorging & 32,5 & hoog \\
\hline MBO horeca & 30 & hoog \\
\hline MBO bewegingen therapie & 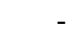 & erg hoog \\
\hline MBO administratie en logistiek & 24,7 & gemiddeld \\
\hline MBO handel & 20,8 & gemiddeld \\
\hline MBO secretariaat & 18,9 & gemiddeld \\
\hline MBO toerisme en recreatie & - & hoog \\
\hline MBO facilitaire dienstverlening & 41,6 & erg hoog \\
\hline MBO ICT & 20,1 & gemiddeld \\
\hline MBO geld, bank en belastingen & 7 & laag \\
\hline MBO verzekeringswezen & - & gemiddeld \\
\hline MBO openbare orde en veiligheid & 6,6 & laag \\
\hline Totaal (inclusief hogere en wetenschappelijke opleidingen) & 24,7 & - \\
\hline
\end{tabular}

Bron: ROA 
Tabel 5.10

Indicator Toekomstperspectieven op de arbeidsmarkt voor schoolverlaters (ITA) en Indicator Toekomstige Knelpunten in de Personeelsvoorziening (ITKP) per opleidingstype, Overijssel, 2001-2006 (alleen lagere en middelbare opleidingen)

\begin{tabular}{|c|c|c|c|c|}
\hline Opleidingstype & ITA & typering & ITKP & typering \\
\hline Basisonderwijs & 0,91 & goed & 1,10 & vrijwel geen \\
\hline VMBO theorie & 0,98 & goed & 1,02 & enige \\
\hline VMBO landbouw en natuurlijke omgeving & 1,05 & redelijk & 1,42 & geen \\
\hline VMBO bouwtechniek & 1,04 & redelijk & 1,15 & vrijwel geen \\
\hline VMBO installatietechniek & - & goed & - & vrijwel geen \\
\hline VMBO mechanische techniek & 0,92 & goed & 1,12 & vrijwel geen \\
\hline VMBO fijnmechanische techniek & - & goed & - & vrijwel geen \\
\hline VMBO motorvoertuigentechniek & - & redelijk & - & geen \\
\hline VMBO elektrotechniek & 1,06 & matig & 1,16 & geen \\
\hline VMBO grafische techniek & - & zeer goed & - & vrijwel geen \\
\hline VMBO brood en banket & - & goed & - & geen \\
\hline VMBO horeca en levensmiddelentechniek & - & redelijk & - & geen \\
\hline VMBO vervoer & 0,83 & zeer goed & 0,97 & groot \\
\hline VMBO administratie, handel en textiel & 1,16 & slecht & 1,44 & geen \\
\hline VMBO verzorging & 1,03 & redelijk & 1,15 & vrijwel geen \\
\hline VMBO beveiliging & - & goed & - & groot \\
\hline HAVO/MWO & 1,03 & redelijk & 1,03 & enige \\
\hline MBO voeding, natuur en milieu & 1,00 & goed & 1,00 & groot \\
\hline MBO groene ruimte & - & slecht & - & geen \\
\hline MBO bouw & 1,05 & redelijk & 1,05 & enige \\
\hline MBO grond-, weg- en waterbouw & - & redelijk & - & enige \\
\hline MBO installatietechniek & - & goed & - & groot \\
\hline MBO werktuigbouw en mechanische techniek & 0,94 & goed & 0,96 & groot \\
\hline MBO fijnmechanische techniek en laboratorium & 0,89 & goed & 0,89 & groot \\
\hline MBO motorvoertuigentechniek en tweewielers & 1,00 & goed & 1,00 & groot \\
\hline MBO vliegtuigtechniek & - & redelijk & - & vrijwel geen \\
\hline MBO operationele techniek & - & goed & - & groot \\
\hline MBO elektrotechniek & 1,03 & redelijk & 1,03 & enige \\
\hline MBO grafische techniek & 1,04 & redelijk & 1,14 & vrijwel geen \\
\hline MBO procestechniek & 0,90 & goed & 0,90 & groot \\
\hline MBO brood en banket & - & matig & - & geen \\
\hline MBO levensmiddelentechniek/vleesverwerking & - & slecht & - & geen \\
\hline MBO vervoer & 0,91 & goed & 0,91 & groot \\
\hline MBO dokters-, tandarts- en dierenartsassistent & - & goed & - & groot \\
\hline MBO apothekersassistent & - & goed & - & groot \\
\hline MBO verpleging en verzorging & 0,99 & goed & 1,02 & enige \\
\hline MBO gezondheidstechniek & - & zeer goed & - & zeer groot \\
\hline MBO sociaal-pedagogisch en welzijn & 1,14 & matig & 1,14 & vrijwel geen \\
\hline MBO uiterlijke verzorging & 1,12 & matig & 1,12 & vrijwel geen \\
\hline MBO horeca & 1,03 & redelijk & 1,03 & enige \\
\hline MBO bewegingen therapie & - & matig & - & vrijwel geen \\
\hline MBO administratie en logistiek & 0,98 & goed & 0,98 & groot \\
\hline MBO handel & 1,03 & redelijk & 1,07 & vrijwel geen \\
\hline MBO secretariaat & 0,94 & goed & 0,94 & groot \\
\hline MBO toerisme en recreatie & - & goed & - & groot \\
\hline MBO facilitaire dienstverlening & 1,04 & redelijk & 1,04 & enige \\
\hline MBO ICT & 0,98 & goed & 0,98 & groot \\
\hline MBO geld, bank en belastingen & 0,84 & zeer goed & 0,95 & groot \\
\hline MBO verzekeringswezen & - & goed & - & enige \\
\hline MBO openbare orde en veiligheid & 0,87 & goed & 0,87 & groot \\
\hline
\end{tabular}

Bron: ROA 
Tabel 5.11

Conjunctuurgevoeligheid per opleidingstype

Opleidingstype

conjunctuur-

typering

gevoeligheid

BASISONDERWIJS

Basisonderwijs

1,09 hoog

VMBO

VMBO Theorie

VMBO theorie

0,85 gemiddeld

VMBO Landbouw en natuurlijke omgeving

VMBO landbouw en natuurlijke omgeving

$0,87 \quad$ gemiddeld

VMBO Techniek

VMBO bouwtechniek

VMBO installatietechniek

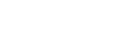

VMBO mechanische techniek

0,93

1,13

VMBO fijnmechanische techniek

VMBO voertuigentechniek

1,03

1,03

VMBO elektrotechniek

0,99
1,14

VMBO grafische techniek

VMBO brood en banket

0,98

VMBO transport en logistiek

0,94

erg hoog

gemiddeld

hoog

hoog

hoog

gemiddeld

hoog

gemiddeld

VMBO Economie

VMBO administratie, handel en mode

$0,89 \quad$ gemiddeld

VMBO consumptief en levensmiddelentechniek

1,19 erg hoog

VMBO Zorg en welzijn

VMBO (uiterlijke) verzorging

1,06 hoog

VMBO Beveiliging

VMBO beveiliging

1,01 hoog

\title{
HAVO/VWO, MBO
}

\author{
HAVO/VWO \\ HAVO/VWO \\ MBO Landbouw en natuurlijke omgeving \\ $M B O$ voeding, natuur en milieu \\ $\mathrm{MBO}$ groene ruimte \\ MBO Techniek \\ MBO laboratorium \\ MBO bouw \\ MBO grond-, weg- en waterbouw \\ MBO installatietechniek \\ MBO fijnmechanische techniek \\ MBO vliegtuigtechniek \\ MBO operationele techniek \\ MBO grafische techniek \\ MBO procestechniek \\ MBO levensmiddelentechniek/ vleesverwerking \\ $\mathrm{MBO}$ vervoer
}

gemiddeld

0,73

laag

0,72 laag

1,06

hoog

1,04

1,04
0,94

0,95

0,84

0,94

0,86

0,98

0,98

1,06

0,75

0,75

0,94

0,98

hoog

gemiddeld gemiddeld gemiddeld gemiddeld gemiddeld gemiddeld gemiddeld hoog

laag gemiddeld gemiddeld 
Tabel 5.11 (vervolg)

Conjunctuurgevoeligheid per opleidingstype

Opleidingstype

conjunctuur-

typering

gevoeligheid

MBO Dienstverlening en gezondheidszorg

MBO dokters-, tandarts- en dierenartsassistent

MBO apothekersassistent

1,12 hoog

$\mathrm{MBO}$ verpleging

erg laag

MBO gezondheidstechniek

erg hoog

MBO sociaal-pedagogisch en welzijn

0,67

1,00

$\mathrm{MBO}$ verzorging

MBO uiterlijke verzorging

1,25

1,34

MBO horeca

1,39

MBO beweging en therapie

gemiddeld

erg hoog

erg hoog

erg hoog

MBO Economie

MBO administratie

0,76

laag

MBO handel

MBO secretariaat

0,87

0,74

0,70

MBO toerisme en recreatie

0,87
0,75

$\mathrm{MBO}$ facilitaire dienstverlening

MBO geld, bank en belastingen

0,92

$M B O$ verzekeringswezen

0,68

gemiddeld

laag

laag

gemiddeld

laag

gemiddeld

laag

MBO Openbare orde en veiligheid

MBO openbare orde en veiligheid

0,85

gemiddeld

\section{HBO}

HBO Onderwijs en tolk en vertaler

HBO lerarenopleiding basisonderwijs

HBO lerarenopleiding talen

HBO lerarenopleiding natuur en techniek

0,49

0,68

0,64

HBO lerarenopleiding economie en maatschappij

0,72

HBO lerarenopleiding lichamelijke opvoeding

0,46

0,68

0,73

HBO lerarenopleiding expressie

0,79

erg laag

laag

erg laag

laag

erg laag

laag

$\mathrm{HBO}$ tolk en vertaler

laag

laag

HBO Landbouw

HBO landbouw en veeteelt

0,80

gemiddeld

HBO milieukunde en levensmiddelentechnologie

0,89

gemiddeld

HBO Techniek

HBO laboratorium

HBO bouwkunde

HBO civiele techniek

HBO werktuigbouwkunde

HBO elektrotechniek

0,63

0,73

0,96

0,86

0,86

HBO informatica

1,25

$\mathrm{HBO}$ chemische technologie

0,85

HBO vervoer en logistiek

0,79

erg laag

laag

gemiddeld

gemiddeld

gemiddeld

erg hoog

gemiddeld

HBO Paramedisch

$\mathrm{HBO}$ verpleegkunde

HBO (fysio)therapie

0,73

laag

$\mathrm{HBO}$ voeding

$\mathrm{HBO}$ radiologie

0,56

laag

0,70

erg laag

0,51

laag

erg laag 
Tabel 5.11 (vervolg)

Conjunctuurgevoeligheid per opleidingstype

Opleidingstype

conjunctuur-

typering

gevoeligheid

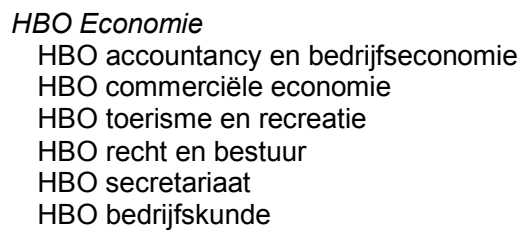

HBO bedrijfskunde

1,09 hoog

$0,99 \quad$ gemiddeld

0,82 gemiddeld

1,09 hoog

0,92 gemiddeld

1,00 gemiddeld

HBO Sociaal-cultureel

HBO communicatie en journalistiek

$0,84 \quad$ gemiddeld

HBO maatschappelijk werk en hulpverlening

0,74

HBO bibliotheek en documentatie

0,89

laag

laag

gemiddeld

HBO Kunst

HBO uitvoerende en beeldende kunsten

$1,14 \quad$ hoog

HBO Openbare orde en veiligheid

HBO openbare orde en veiligheid

$0,81 \quad$ gemiddeld

Wo

WO Letteren en theologie

WO letteren

WO theologie

$0,93 \quad$ gemiddeld

$0,63 \quad$ erg laag

WO Landbouw en milieukunde

WO landbouw en milieukunde

$0,91 \quad$ gemiddeld

WO Techniek

WO wiskunde en natuurwetenschappen

WO bouwkunde

WO civiele techniek

WO werktuigbouwkunde

WO elektrotechniek

WO informatica en bestuurlijke informatiekunde

WO Medisch

WO (dier)geneeskunde

WO tandheelkunde

WO farmacie en medische biologie

1,03 hoog

1,93 erg hoog

1,44 erg hoog

1,02 hoog

1,05 hoog

1,12 hoog

WO Economie

WO econom(etr)ie

WO bedrijfskunde

0,39

WO accountancy en belastingen

$0,39 \quad$ erg laag

0,38 erg laag

$0,78 \quad$ laag

WO rechten en bestuurskunde

1,01 hoog

0,97 gemiddeld

1,42 erg hoog

1,62 erg hoog

WO Sociaal-cultureel

WO sociale wetenschappen

0,97 gemiddeld

WO Kunst

WO kunstwetenschappen

$1,17 \quad$ hoog 
Tabel 5.12

Uitwijkmogelijkheden naar verschillende beroepsgroepen per opleidingstype, Overijssel, gemiddelde 2000-2001

Opleidingstype

spreidings-

typering

index

BASISONDERWIJS

Basisonderwijs

20,06

erg hoog

VMBO

VMBO Theorie

VMBO theorie

erg hoog

VMBO Landbouw en natuurlijke omgeving

VMBO landbouw en natuurlijke omgeving

$7,74 \quad$ hoog

VMBO Techniek

VMBO bouwtechniek

VMBO installatietechniek

VMBO mechanische techniek

VMBO fijnmechanische techniek

VMBO voertuigentechniek

VMBO elektrotechniek

VMBO grafische techniek

4,09

1,48

10,89

VMBO brood en banket

6,94

9,13

2,07

4,02

VMBO transport en logistiek

2,11

gemiddeld

laag

erg hoog

hoog

hoog

laag

gemiddeld

VMBO Economie

VMBO administratie, handel en mode

13,21 erg hoog

VMBO consumptief en levensmiddelentechniek

6,75 hoog

VMBO Zorg en welzijn

VMBO (uiterlijke) verzorging

10,93 erg hoog

VMBO Beveiliging

VMBO beveiliging

laag

\title{
HAVO/VWO, MBO
}

\author{
HAVO/VWO \\ HAVO/VWO \\ MBO Landbouw en natuurlijke omgeving \\ $M B O$ voeding, natuur en milieu \\ $\mathrm{MBO}$ groene ruimte \\ MBO Techniek \\ MBO laboratorium \\ MBO bouw \\ MBO grond-, weg- en waterbouw \\ MBO installatietechniek \\ MBO werktuigbouw en mechanische techniek \\ MBO motorvoertuigentechniek en tweewielers \\ MBO vliegtuigtechniek \\ MBO operationele techniek \\ MBO elektrotechniek \\ MBO grafische techniek \\ MBO procestechniek \\ MBO levensmiddelentechniek/ vleesverwerking \\ $\mathrm{MBO}$ vervoer
}

erg hoog

4,70

4,42

gemiddeld

1,71

6,38

2,77

2,77
4,49

$-$

2,43

8,71

5,05

5,71

5,05

5,71

5,80

hoog

gemiddeld

gemiddeld

laag

gemiddeld

laag

gemiddeld

laag

hoog

gemiddeld

gemiddeld

gemiddeld

gemiddeld

gemiddeld 
Tabel 5.12 (vervolg)

Uitwijkmogelijkheden naar verschillende beroepsgroepen per opleidingstype, Overijssel, gemiddelde 2000-2001

typering

index

MBO Dienstverlening en gezondheidszorg

MBO dokters-, tandarts- en dierenartsassistent

MBO apothekersassistent

3,22

2,73

3,83

$M B O$ verpleging

1,00

MBO gezondheidstechniek

MBO sociaal-pedagogisch en welzijn

$M B O$ verzorging

MBO uiterlijke verzorging

6,31

3,94

MBO horeca

6,90

MBO beweging en therapie

7,18

gemiddeld

laag

gemiddeld

erg laag

hoog

gemiddeld

gemiddeld

hoog

MBO Economie

MBO administratie en logistiek $\quad 6,66$

MBO handel 14,35

MBO secretariaat $\quad 4,88$

MBO toerisme en recreatie

5,63

MBO facilitaire dienstverlening

12,95

3,26

3,97

MBO geld, bank en belastingen

3,08

hoog

MBO verzekeringswezen

gemiddeld

erg hoog

gemiddeld

gemiddeld

erg hoog

gemiddeld

gemiddeld

gemiddeld

MBO Openbare orde en veiligheid

MBO openbare orde en veiligheid

hoog

\section{HBO}

$H B O$ Onderwijs en tolk en vertaler

HBO lerarenopleiding basisonderwijs $\quad 1,48$

HBO lerarenopleiding talen

3,31
3,89

HBO lerarenopleiding natuur en techniek

HBO lerarenopleiding economie en maatschappij

HBO lerarenopleiding lichamelijke opvoeding

2,67
3,55

O lerarenopleiding medisch en verzorging

erg laag

gemiddeld

gemiddeld

HBO lerarenopleiding expressie

hoog

$\mathrm{HBO}$ tolk en vertaler

gemiddeld

gemiddeld

HBO Landbouw

$\mathrm{HBO}$ landbouw en veeteelt

HBO milieukunde en levensmiddelentechnologie

gemiddeld

gemiddeld

HBO Techniek

HBO laboratorium

4,93

HBO bouwkunde

2,99

gemiddeld

HBO civiele techniek

gemiddeld

HBO werktuigbouwkunde

3,46

HBO elektrotechniek

10,79

gemiddeld

HBO informatica

10,35

$\mathrm{HBO}$ chemische technologie

2,55

hoog

hoog

3,67

laag

HBO vervoer en logistiek

gemiddeld

HBO Paramedisch

$\mathrm{HBO}$ verpleegkunde

$\mathrm{HBO}$ voeding

HBO radiologie 
Tabel 5.12 (vervolg)

Uitwijkmogelijkheden naar verschillende beroepsgroepen per opleidingstype, Overijssel, gemiddelde 2000-2001

\begin{tabular}{lcc}
\hline Opleidingstype & $\begin{array}{c}\text { spreidings- } \\
\text { index }\end{array}$ & typering \\
\hline
\end{tabular}

\section{HBO Economie}

HBO accountancy en bedrijfseconomie

HBO commerciële economie

7,83 hoog

4,60

gemiddeld

$\mathrm{HBO}$ toerisme en recreatie

HBO recht en bestuur $\quad 9,01$

HBO secretariaat $\quad 2,79$

gemiddeld

HBO bedrijfskunde

16,58

laag

erg hoog

HBO Sociaal-cultureel

HBO communicatie en journalistiek

2,69 laag

HBO maatschappelijk werk en hulpverlening

4,11

HBO personeel en arbeid

gemiddeld

HBO bibliotheek en documentatie

1,59

gemiddeld

HBO Kunst

HBO uitvoerende en beeldende kunsten

7,52 hoog

HBO Openbare orde en veiligheid

$\mathrm{HBO}$ openbare orde en veiligheid

$1,77 \quad$ laag

wo

WO Letteren en theologie
WO letteren

WO theologie

4,05 gemiddeld

WO Landbouw en milieukunde

WO landbouw en milieukunde

gemiddeld

WO Techniek

WO wiskunde en natuurwetenschappen

WO bouwkunde

WO civiele techniek

WO werktuigbouwkunde

1,71

laag

WO elektrotechniek

WO informatica en bestuurlijke informatiekunde

9,13 hoog

1,11 erg laag

1,86 laag

$4,00 \quad$ gemiddeld

3,24 gemiddeld

WO Medisch

WO (dier)geneeskunde

WO tandheelkunde

$2,45 \quad$ laag

WO farmacie en medische biologie

1,24 erg laag

1,31 erg laag

$1,00 \quad$ erg laag

WO Economie

WO econom(etr)ie

WO bedrijfskunde

5,94 gemiddeld

6,21

gemiddeld

WO rechten en bestuurskunde

$\begin{array}{ll}3,86 & \text { gemiddeld } \\ 3,76 & \text { gemiddeld }\end{array}$

WO Sociaal-cultureel

WO sociale wetenschappen

9,47 hoog

WO Kunst

WO kunstwetenschappen 
Tabel 5.13

Substitutiemogelijkheden tussen mensen met uiteenlopende opleidingsachtergronden per beroepsgroep, Overijssel, gemiddelde 2000-2001

\begin{tabular}{lcc}
\hline Opleidingstype & $\begin{array}{c}\text { spreidings- } \\
\text { index }\end{array}$ & typering \\
\hline
\end{tabular}

\section{PEDAGOGISCHE BEROEPEN}

Leraar basisonderwijs

1,34

Docenten exacte, medische en verzorgende vakken (2e graads)

Docenten exacte, medische en verzorgende vakken (1e graads)

Docenten landbouw en techniek (2e graads)

Docenten landbouw en techniek (1e graads)

Docenten economisch-administratieve vakken (2e graads)

Docenten economisch-administratieve vakken (1e graads)

Docenten talen en expressie

Docenten letteren (1e graads)

Docenten sociale vakken (2e graads)

Docenten sociale vakken (1e graads)

Docenten 2 e graads zonder specialisatie

Docent 1 e graads zonder specialisatie

Onderwijskundig medewerkers

Onderwijskundigen en pedagogen

Rij-instructeurs

Zweminstructeurs

Sportinstructeurs

\section{CULTURELE BEROEPEN}

Tolken, vertalers en schrijvers

Bibliotheekassistenten

Bibliothecarissen

Grafisch ontwerpers

Kunstenaars

Geestelijk verzorgers

Geestelijken

Journalisten

Taalkundigen

laag

gemiddeld

laag

gemiddeld

laag

gemiddeld

erg laag

laag

laag

gemiddeld

laag

erg laag

gemiddeld

\section{AGRARISCHE BEROEPEN}

Agrarische hulparbeiders

Agrarische arbeiders

Agrarische vakkrachten

Milieuhygiënisten en agrarisch vertegenwoordigers

Landbouwkundigen

Landbouwmachinebestuurders en vissers

Agrarische bedrijfshoofden

TECHNISCHE, AMBACHTS- EN INDUSTRIEBEROEPEN

Productiemedewerkers

Laboratorium-assistenten

Laboranten

Technisch analisten

Natuurwetenschappers

Conciërges

Hoofden technische dienst

erg laag

hoog

laag

gemiddeld

erg laag

gemiddeld

hoog

Werktuigbouwkundigen

Bouwvakkers

Aannemers en installateurs

Architecten en bouwkundig projectleiders

laag

laag

laag

hoog

gemiddeld

laag

gemiddeld

gemiddeld

gemiddeld

laag 
Tabel 5.13 (vervolg)

Substitutiemogelijkheden tussen mensen met uiteenlopende opleidingsachtergronden per beroepsgroep, Overijssel, gemiddelde 2000-2001

\begin{tabular}{lcc}
\hline Opleidingstype & spreidings- \\
& index & typering \\
& & hoog \\
Weg- en waterbouwkundige arbeiders & 6,90 & hoog \\
Weg- en waterbouwkundige vakkrachten & 9,49 & gemiddeld \\
Weg- en waterbouwkundig ontwerpers en projectleiders & 3,21 & hoog \\
Metaalarbeiders & 7,28 & gemiddeld \\
Bankwerkers en lassers & 6,05 & gemiddeld \\
Bedrijfshoofden metaalbewerking & 3,00 & hoog \\
Assembleurs & 6,78 & gemiddeld \\
Monteurs & 9,50 & laag \\
Werktuigbouwkundig ontwerpers en hoofden technische dienst & 6,25 & gemiddeld \\
Elektronicamonteurs & 2,22 & gemiddeld \\
Monteurs en controleurs elektrotechnische producten & 5,75 & laag \\
Elektromonteurs & 3,00 & laag \\
Elektrotechnisch ontwerpers en bedrijfshoofden & 1,94 & gemiddeld \\
Elektrotechnici & 1,99 & hoog \\
Grafisch productiepersoneel & 6,21 & hoog \\
Grafische vakkrachten & 7,40 & erg hoog \\
Mechanisch operators & 9,95 & gemiddeld \\
Procesoperators & 13,57 & gemiddeld \\
Procestechnologen & 3,18 & gemiddeld \\
Materiaalkundigen & 4,15 & gemiddeld \\
Confectie-arbeiders & 5,45 & 3,51 \\
Schoen- en kleermakers & &
\end{tabular}

TRANSPORT BEROEPEN

Laders en lossers $\quad 12,17$

Chauffeurs

Schippers en conducteurs

Vliegers, scheepskapiteins en leidinggevenden transport

Stewards

\section{MEDISCHE EN PARAMEDISCHE BEROEPEN}

Verpleeghulpen en leerling-verpleegkundigen

Verplegenden en doktersassistenten

Therapeuten en verpleegkundigen

Artsen

Apothekersassistenten en medisch laboranten

Medisch analisten

Apothekers

Afdelingshoofden zorginstelling

\section{ECONOMISCH-ADMINISTRATIEVE BEROEPEN}

Kantoorhulpen, inpakkers en colporteurs

Ondersteunende administratieve hulpkrachten

Bedrijfshoofden

erg hoog

hoog

laag

gemiddeld

erg laag

Economen

Productieplanners

Organisatie-adviseurs

Organisatiedeskundigen

Receptionisten en administratieve employés

Boekhouders en secretaresses

Assistent accountants

Accountants

Verzekeringsagenten

Commercieel employés laag

gemiddeld

laag

gemiddeld

laag

erg laag

laag

$\begin{aligned} 5,01 & \text { gemiddeld } \\ 2,44 & \text { laag } \\ 12,13 & \text { erg hoog } \\ 5,78 & \text { gemiddeld } \\ 14,48 & \text { erg hoog } \\ 7,47 & \text { hoog } \\ 2,56 & \text { laag } \\ 10,21 & \text { erg hoog } \\ 9,16 & \text { hoog } \\ 9,54 & \text { hoog } \\ 3,61 & \text { gemiddeld } \\ 5,20 & \text { gemiddeld } \\ 14,92 & \text { erg hoog }\end{aligned}$


Tabel 5.13 (vervolg)

Substitutiemogelijkheden tussen mensen met uiteenlopende opleidingsachtergronden per beroepsgroep, Overijssel, gemiddelde 2000-2001

\begin{tabular}{lc}
\hline Opleidingstype & $\begin{array}{c}\text { spreidings- } \\
\text { index }\end{array}$ \\
\hline
\end{tabular}

Commercieel medewerkers

20,11

6,56

3,11

Technisch-bedrijfskundig medewerkers

Juridisch en fiscaal medewerkers

Juridisch, bestuurlijk medewerkers

Juristen

Administratieve transportemployés

Leidinggevenden

Managers

Medisch secretaresses

\section{erg hoog \\ hoog \\ gemiddeld \\ hoog \\ gemiddeld \\ gemiddeld \\ hoog \\ erg hoog \\ erg hoog \\ gemiddeld}

INFORMATICA BEROEPEN

Programmeurs

gemiddeld

Systeemanalisten

Informatici

Technisch systeemanalisten

hoog

hoog

gemiddeld

\section{SOCIAAL CULTURELE BEROEPEN}

Activiteitenbegeleiders en medewerkers arbeidsbemiddeling Medewerkers sociaal-cultureel werk en personeel en arbeid

Hoofden sociaal-cultureel werk en personeel en arbeid

hoog

Sociaal-wetenschappelijk medewerker

laag

gemiddeld

erg laag

VERZORGENDE EN DIENSTVERLENENDE BEROEPEN

Vakkenvullers

Verkopers

Hulpkrachten horeca en verzorging

Ziekenverzorgenden

Verzorgend personeel

Café- en snackbarhouders

Bedrijfshoofden horeca

Bakkers en slagers

gemiddeld

hoog

erg hoog

hoog

hoog

erg laag

hoog

gemiddeld

gemiddeld

gemiddeld

\section{OPENBARE ORDE- EN VEILIGHEIDSBEROEPEN}

Aspirant politieagenten, soldaten en beveiligingshulpkrachten

$\begin{aligned} 11,77 & \text { erg hoog } \\ 2,96 & \text { gemiddeld } \\ 1,95 & \text { laag } \\ 1,60 & \text { erg laag }\end{aligned}$



6 Classificaties 



\section{Basisonderwijs}

00000-20199

VMBO, VMBO theorie

VMBO theorie

002 VMBO theorie

VMBO Landbouw en natuurlijke omgeving

003 VMBO landbouw en natuurlijke omgeving

VMBO Techniek

VMBO bouwtechniek

VMBO installatietechniek

VMBO mechanische techniek

VMBO fijnmechanische techniek

VMBO motorvoertuigentechniek

VMBO elektrotechniek

VMBO grafische techniek

VMBO brood en banket

VMBO horeca en levensmiddelentechniek

VMBO vervoe

VMBO techniek overig

VMBO Economie

015 VMBO administratie, handel en textiel

$\checkmark M B O$ Verzorging

$016 \quad$ VMBO verzorging

VMBO Openbare orde en veiligheid

017

VMBO beveiliging

VMBO Overig

VMBO overig

MBO, HAVO/VWO

HAVO/VWO

019 HAVO/VWO

$M B O$ Landbouw en natuurlijke omgeving

020 MBO voeding, natuur en milieu

$021 \quad$ MBO groene ruimte

MBO Techniek

022 MBO bouw

023 MBO grond-, weg- en waterbouw

024 MBO installatietechniek

$025 \mathrm{MBO}$ werktuigbouw \& mechanische techniek

30100-30199

33616

33635

33641

$33650-33659$

33660-33669

33676

34100-34399

39100-39399

39800-39999

40100-40199

43616,43816

MBO motorvoertuigentechniek en tweewielers

MBO vliegtuigtechniek

43645
30637, 32100-32999

33610-33615, 33617-33629

$33631,33633,33638$

$33677,34430,38140,38340$

33100-33199, 33642-33649,

33670-33672, 33674-33675,

33678-33684, 33686-33699

$33673,33685,36110-36699$

$30667,30671,35100-35499$, 37100-37199, 38100-38139, $38180-38199,38330$

30690, 31100-31199, 31610, $38430,38600-38699$,

42110-42129, 42150-42169,

42188-42199, 42220-42999

$42130,42175,42183$

43611-43615, 43618-43619,

43811-43815, 43818-43819

43623-43625, 43823-43825

42210, 43631, 43633,

43638, 43643, 43647-43648,

43833, 43838, 43843,

43847-43848,

44231, 44250-44299

MBO fijnmechanische techniek en laboratorium $\quad 43100-43199,45210-45219,43635,43835,45280$ 


\section{Overzicht van opleidingstypen (vervolg)}

Opleidingsniveau

Opleidingscategorie

Nr. Opleidingstype

SOI

\begin{tabular}{|c|c|c|}
\hline 029 & MBO operationele techniek & 43646 \\
\hline 030 & MBO elektrotechniek & $43650-43659,43850-43859$ \\
\hline 031 & MBO grafische techniek & $43660-43669,43867-43869$ \\
\hline 032 & MBO procestechniek & $\begin{array}{l}43674,43675,43678,43679 \\
43874,43875,43878,43879\end{array}$ \\
\hline 033 & MBO brood en banket & 43676,43876 \\
\hline 034 & MBO levensmiddelentechniek/ & \\
\hline \multirow[t]{3}{*}{035} & MBO vervoer & $\begin{array}{l}40657,44100-44199,44210 \\
44238-44241,44248 \\
44300-44999\end{array}$ \\
\hline & MBO techniek overig & $\begin{array}{l}\text { 43671-43673, 43682, } \\
\text { 43688-43699, 43888-43999 }\end{array}$ \\
\hline & MBO Dienstverlening en gezondheidszorg & \\
\hline 037 & MBO dokters-, tandarts- en dierenartsassistent & $45118,45138,45160$ \\
\hline 038 & MBO apothekersassistent & 45220 \\
\hline 039 & MBO verpleging & $\begin{array}{l}45120,45380,41610,45430,45480, \\
48110-48129, \\
48180-48199,48320\end{array}$ \\
\hline 040 & MBO gezondheidstechniek & $45230-45239$ \\
\hline 041 & MBO sociaal-pedagogisch en welzijn & $47100-47199$ \\
\hline 042 & MBO uiterlijke verzorging & 48130,48330 \\
\hline 043 & MBO horeca & 48140,48340 \\
\hline \multirow[t]{2}{*}{044} & MBO beweging en therapie & $\begin{array}{l}40667,45140-45159 \\
45161-45179,45181-45199 \\
45240-45249,45410,45900\end{array}$ \\
\hline & MBO Economie & \\
\hline 045 & MBO administratie en logistiek & $\begin{array}{l}46110,46133,46138,46141 \\
46148,46180-46199 \\
46600-46629,46690\end{array}$ \\
\hline 046 & MBO handel & $\begin{array}{l}43617,43685,43817,43885 \\
46143,46150-46159,46280\end{array}$ \\
\hline 047 & MBO secretariaat & $45180,45310,46131$ \\
\hline 048 & MBO toerisme en recreatie & 46142 \\
\hline 049 & MBO facilitaire dienstverlening & $46120-46129,46220$ \\
\hline 050 & MBO ICT & 46135 \\
\hline 051 & MBO geld, bank en belastingen & 46145,46630 \\
\hline 052 & $\begin{array}{l}\text { MBO verzekeringswezen } \\
M B O \text { Openbare orde en veiligheid }\end{array}$ & 46146 \\
\hline \multirow[t]{3}{*}{053} & $\begin{array}{l}\text { MBO openbare orde en veiligheid } \\
\text { MBO Overig }\end{array}$ & $49100-49799$ \\
\hline & MBO overig & $\begin{array}{l}40617-40656,40658, \\
40670-40699, \\
41110-41199,46240, \\
48400-48699,49800-49999\end{array}$ \\
\hline & HBO & \\
\hline 055 & $\begin{array}{l}\text { HBO Onderwijs en tolk en vertaler } \\
\text { HBO lerarenopleiding basisonderwijs }\end{array}$ & $\begin{array}{l}40611,50611-50617 \\
50690-50699, \\
60611-60617,60692\end{array}$ \\
\hline 056 & HBO lerarenopleiding talen & $\begin{array}{l}50620-50625,50628,50629 \\
60620-60625,60628,60629 \\
70621-70625,70628,70629\end{array}$ \\
\hline 057 & HBO lerarenopleiding natuur en techniek & $\begin{array}{l}50630-50659,60630-60659 \\
70630-70635\end{array}$ \\
\hline 058 & HBO lerarenopleiding economie en maatschappij & $\begin{array}{l}50626,50627,50660-50666, \\
57181,60626,60627,60660-60666,70626 \\
70627,70660-70666\end{array}$ \\
\hline
\end{tabular}




\section{Overzicht van opleidingstypen (vervolg)}

Opleidingsniveau

Opleidingscategorie

Nr. Opleidingstype SOI

\begin{tabular}{|c|c|c|}
\hline 059 & HBO lerarenopleiding lichamelijke opvoeding & 50667,60667 \\
\hline 060 & HBO lerarenopleiding medisch en verzorging & $50670-50679,60670-60679$ \\
\hline 061 & HBO lerarenopleiding expressie & $50680-50689,60680-60689,70680-70689$ \\
\hline 062 & $\begin{array}{l}\text { HBO tolk en vertaler } \\
\text { HBO Landbouw }\end{array}$ & $51100-51199$ \\
\hline 063 & HBO landbouw en veeteelt & 52110,52158 \\
\hline 064 & $\begin{array}{l}\text { HBO milieukunde en levensmiddelentechnologie } \\
\text { HBO Techniek }\end{array}$ & $52128-52130,52171-52299,52900,53677,53678$ \\
\hline 065 & HBO laboratorium & $53140,53149,53160,55210,55220$ \\
\hline 066 & HBO bouwkunde & $53610-53619,53810-53819$ \\
\hline 067 & HBO civiele techniek & $53620-53629,53820-53829$ \\
\hline 068 & HBO werktuigbouwkunde & $53631-53649,53830-53849$ \\
\hline 069 & HBO elektrotechniek & $\begin{array}{l}53110-53139,53150,53170-53190,53650-53651, \\
53653-53655,53682,53683\end{array}$ \\
\hline 070 & HBO informatica & 53652,56135 \\
\hline 071 & HBO chemische technologie & $53670-53676$ \\
\hline 072 & $\begin{array}{l}\text { HBO vervoer en logistiek } \\
\text { HBO Paramedisch }\end{array}$ & $54100-54999$ \\
\hline 073 & HBO verpleegkunde & 55120,55380 \\
\hline 074 & HBO (fysio)therapie & $55140-55149,55151,55153,55180,55238$ \\
\hline 075 & HBO voeding & 55420,58180 \\
\hline \multirow[t]{3}{*}{076} & HBO radiologie & $55241-55243$ \\
\hline & HBO paramedisch overig & $\begin{array}{l}55110-55119,55130-55133,55160,55190-55199, \\
55231,55248,55280,55480\end{array}$ \\
\hline & HBO Economie & \\
\hline 078 & HBO accountancy en bedrijfseconomie & $\begin{array}{l}56110,56133,56138,56210,56240,56249, \\
56630\end{array}$ \\
\hline 079 & HBO commerciële economie & $56143-56180$ \\
\hline 080 & HBO toerisme en recreatie & 56142 \\
\hline 081 & HBO recht en bestuur & $56611-56629,56690$ \\
\hline 082 & HBO secretariaat & 55310,56131 \\
\hline 083 & $\begin{array}{l}\text { HBO bedrijfskunde } \\
\text { HBO Sociaal-cultureel }\end{array}$ & $52310,52350,52380,56120,56220$ \\
\hline 084 & HBO communicatie en journalistiek & 56141,57120 \\
\hline 085 & HBO maatschappelijk werk en hulpverlening & $51610,57111,57115-57119,57188-57199$ \\
\hline 086 & HBO personeelswerk & 57113 \\
\hline \multirow[t]{2}{*}{087} & HBO bibliotheek en documentatie & 57130 \\
\hline & $\begin{array}{l}\text { HBO sociaal-cultureel overig } \\
\text { HBO Kunst }\end{array}$ & $57141,57143,57145-57165$ \\
\hline 089 & $\begin{array}{l}\text { HBO uitvoerende en beeldende kunsten } \\
\text { HBO Openbare orde en veiligheid }\end{array}$ & $58610-58640,58680-58699,68610$ \\
\hline \multirow[t]{4}{*}{090} & $\begin{array}{l}\text { HBO openbare orde en veiligheid } \\
\text { HBO Overig }\end{array}$ & $59100-59499$ \\
\hline & HBO overig & $\begin{array}{l}53685-53699,53868,53885, \\
53900,56190-56199, \\
58110-58125,58190,58340,58900-58999, \\
59900-59999\end{array}$ \\
\hline & WO & \\
\hline & WO Letteren en theologie & \\
\hline 092 & WO letteren & $61100-61199,71100-71199$ \\
\hline 093 & $\begin{array}{l}\text { WO theologie } \\
\text { WO Landbouw en milieukunde }\end{array}$ & 61610,71610 \\
\hline \multirow[t]{2}{*}{094} & WO landbouw en milieukunde & $\begin{array}{l}62110-62130,62158,62170-62180,62182-62189 \\
62200-62999,72175\end{array}$ \\
\hline & WO Techniek & \\
\hline 095 & WO wiskunde en natuurwetenschappen & $\begin{array}{l}\text { 63110-63199, 63631, 63670-63688, 73110-73199, } \\
73674,73675\end{array}$ \\
\hline 096 & WO bouwkunde & $63613-63618,63818,73618$ \\
\hline
\end{tabular}




\title{
Overzicht van opleidingstypen (vervolg)
}

\author{
Opleidingsniveau \\ Opleidingscategorie \\ Nr. Opleidingstype SOl

\begin{tabular}{|c|c|c|}
\hline 097 & WO civiele techniek & $63623-63625,73623$ \\
\hline 098 & WO werktuigbouwkunde & $\begin{array}{l}62181,63643-63649 \\
73645-73648\end{array}$ \\
\hline 099 & WO elektrotechniek & $\begin{array}{l}\text { 63650-63651, 63653-63659, 72181, 73650-73651, } \\
73653-73659\end{array}$ \\
\hline \multirow[t]{2}{*}{100} & WO informatica en bestuurlijke informatiekunde & $63652,66135,73652,76135$ \\
\hline & WO Medisch & \\
\hline 101 & WO (dier)geneeskunde & $65111,65160,75111,75160$ \\
\hline 102 & WO tandheelkunde & 65131,75131 \\
\hline 103 & $\begin{array}{l}\text { WO farmacie en medische biologie } \\
\text { WO Economie }\end{array}$ & $65200-65299,75200-75299$ \\
\hline 104 & WO econom(etr)ie & $\begin{array}{l}\text { 66110, 66141-66219, 66221-66240, 76110, } \\
76141-76219\end{array}$ \\
\hline 105 & WO bedrijfskunde & $66120,66220,76120$ \\
\hline 106 & WO accountancy en belastingen & $66133,66630,76133,76630$ \\
\hline \multirow[t]{2}{*}{107} & WO rechten en bestuurskunde & $\begin{array}{l}66118,66610-66629 \\
66631-66699,76118,76610-76629\end{array}$ \\
\hline & WO Sociaal-cultureel & \\
\hline \multirow[t]{2}{*}{108} & WO sociale wetenschappen & $\begin{array}{l}65148,65180-65199,67120,67130,67141- \\
67188,68110,68180,75148,75151,75180, \\
77130,77141-77188\end{array}$ \\
\hline & $\begin{array}{l}\text { WO sociaal-cultureel overig } \\
\text { WO Kunst }\end{array}$ & $67110-67119,67190,77113$ \\
\hline 112 & $\begin{array}{l}\text { WO kunstwetenschappen } \\
\text { WO Overig }\end{array}$ & 68640 \\
\hline - & WO overig & $\begin{array}{l}63690,63900,65380,65480,65900,68690 \\
69150-69999\end{array}$ \\
\hline
\end{tabular}

Noot: De classificatie die gehanteerd wordt in hoofdstuk 1 van deze Statistische Bijlage wijkt op twee punten licht af van de indeling die hier wordt weergegeven. Het opleidingstype MBO fijnmechanische techniek en laboratium is in hoofdstuk 1 uitgesplitst in MBO Laboratium en MBO fijnmechanische techniek. In plaats van het opleidingstype MBO verpleging en verzorging worden in hoofdstuk 1 twee opleidingstypen - $M B O$ verzorging en $M B O$ verpleging - onderscheiden. 


\section{Beroepsgroepen, volgorde ROA}

ROA-beroepsklasse

ROA-nr. SBC ROA-beroepsgroep

\section{PEDAGOGISCHE BEROEPEN}

623 Leraar basisonderwijs

625 Docenten exacte, medische en verzorgende vakken (2e graads)

825 Docenten exacte, medische en verzorgende vakken (1e graads)

626 Docenten landbouw en techniek (2e graads)

826 Docenten landbouw en techniek (1e graads)

631 Docenten economisch-administratieve vakken (2e graads)

831 Docenten economisch-administratieve vakken (1e graads)

633 Docenten talen en expressie

833 Docenten letteren (1e graads)

634 Docenten sociale vakken (2e graads)

834 Docenten sociale vakken (1e graads)

621 Docenten 2e graads zonder specialisatie

821 Docent 1e graads zonder specialisatie

622 Onderwijskundig medewerkers

822 Onderwijskundigen en pedagogen

427 Rij-instructeurs

234 Zweminstructeurs

434 Sportinstructeurs

\section{CULTURELE BEROEPEN}

19752 Tolken, vertalers en schrijvers

20553 Bibliotheekassistenten

21753 Bibliothecarissen

$22 \quad 554$ Grafisch ontwerpers

23754 Kunstenaars

24762 Geestelijk verzorgers

25962 Geestelijken

26764 Journalisten

27964 Taalkundigen

\section{AGRARISCHE BEROEPEN}

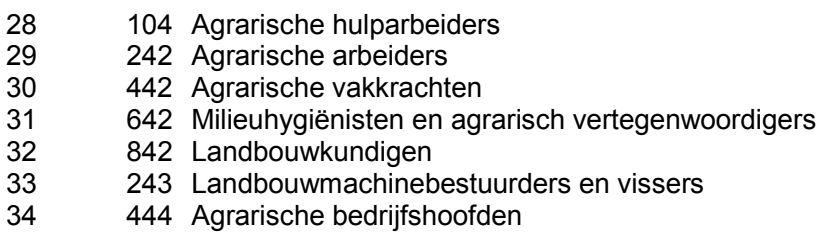

\section{TECHNISCHE, AMBACHTS- EN INDUSTRIEBEROEPEN}

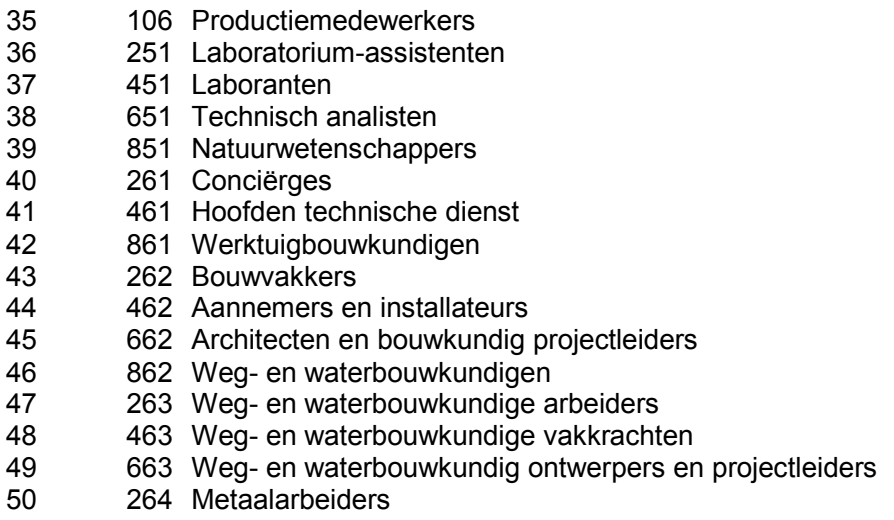




\section{Beroepsgroepen, volgorde ROA (vervolg)}

ROA-beroepsklasse

ROA-nr. SBC ROA-beroepsgroep

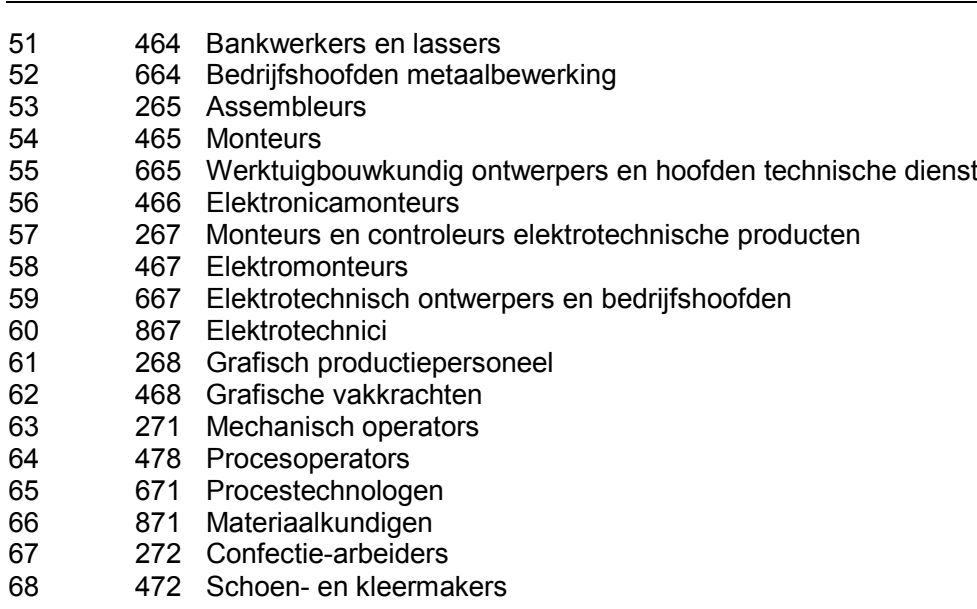

\section{TRANSPORTBEROEPEN}

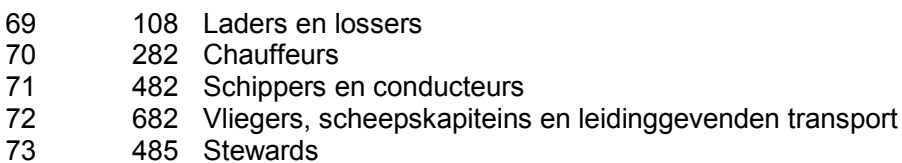

\section{MEDISCHE EN PARAMEDISCHE BEROEPEN}

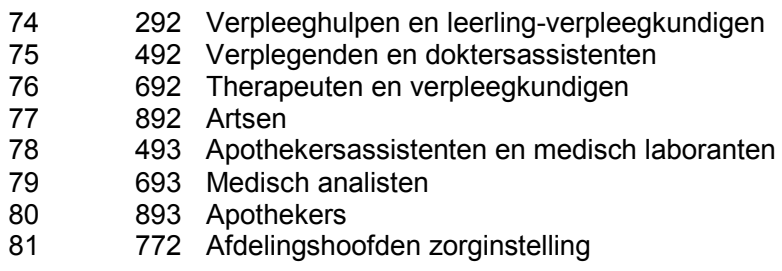

\section{ECONOMISCH-ADMINISTRATIEVE BEROEPEN}

$\begin{array}{lll}82 & 101 & \text { Kantoorhulpen, inpakkers en colporteurs } \\ 83 & 211 & \text { Ondersteunende administratieve hulpkrachten } \\ 84 & 712 & \text { Bedrijfshoofden } \\ 85 & 912 & \text { Economen } \\ 86 & 513 & \text { Productieplanners } \\ 87 & 713 & \text { Organisatie-adviseurs } \\ 88 & 913 & \text { Organisatiedeskundigen } \\ 89 & 315 & \text { Receptionisten en administratieve employés } \\ 90 & 515 & \text { Boekhouders en secretaresses } \\ 91 & 715 & \text { Assistent accountants } \\ 92 & 915 & \text { Accountants } \\ 93 & 316 & \text { Verzekeringsagenten } \\ 94 & 516 & \text { Commercieel employés } \\ 95 & 716 & \text { Commercieel medewerkers } \\ 96 & 521 & \text { Technisch-commercieel employés } \\ 97 & 721 & \text { Technisch-bedrifskundig medewerkers } \\ 98 & 532 & \text { Juridisch en fiscaal medewerkers } \\ 99 & 732 & \text { Juridisch, bestuurlijk medewerkers } \\ 100 & 932 & \text { Juristen } \\ 101 & 484 & \text { Administratieve transportemployés } \\ 102 & 788 & \text { Leidinggevenden }\end{array}$


Beroepsgroepen, volgorde ROA (vervolg)

ROA-beroepsklasse

ROA-nr. SBC ROA-beroepsgroep

\begin{tabular}{lrl}
\hline 103 & 988 & Managers \\
104 & 494 & Medisch secretaresses \\
& & \\
INFORMATICA & BEROEPEN \\
105 & 514 & Programmeurs \\
106 & 714 & Systeemanalisten \\
107 & 914 & Informatici \\
108 & 666 & Technisch systeemanalisten
\end{tabular}

\section{SOCIAAL-CULTURELE BEROEPEN}

$\begin{array}{lll}109 & 563 & \text { Activiteitenbegeleiders en medewerkers arbeidsbemiddeling } \\ 110 & 763 & \text { Medewerkers sociaal-cultureel werk en personeel en arbeid } \\ 111 & 963 & \text { Hoofden sociaal-cultureel werk en personeel en arbeid } \\ 112 & 765 & \text { Sociaal-wetenschappelijk medewerkers } \\ 113 & 965 & \text { Sociaal-wetenschappelijk onderzoekers }\end{array}$

\section{VERZORGENDE EN DIENSTVERLENENDE BEROEPEN}

$\begin{array}{lll}114 & 112 & \text { Vakkenvullers } \\ 115 & 117 & \text { Interieurverzorgers } \\ 116 & 317 & \text { Verkopers } \\ 117 & 517 & \text { Winkeliers } \\ 118 & 372 & \text { Hulpkrachten horeca en verzorging } \\ 119 & 495 & \text { Ziekenverzorgenden } \\ 120 & 572 & \text { Verzorgend personeel } \\ 121 & 373 & \text { Café- en snackbarhouders } \\ 122 & 573 & \text { Bedrijfshoofden horeca } \\ 123 & 479 & \text { Bakkers en slagers }\end{array}$

\section{OPENBARE ORDE- EN VEILIGHEIDSBEROEPEN}

124342 Aspirant politieagenten, soldaten en beveiligingshulpkrachten

125542 Politieagenten, onderofficieren en beveiligingsemployés

126742 Politie-inspecteurs en officieren

$127 \quad 473$ Brandweerlieden 
Beroepsgroepen, volgens SBC '92

Nr. SBC Beroepsklasse Beroepsgroep (CBS-naam) Beroepsgroep (ROA-naam)

$\begin{aligned} \mathbf{1 1} & \text { ELEMENTAIRE BEROEPEN } \\ 101 & \text { Algemene elementaire beroepen } \\ 104 & \text { Elementaire agrarische beroepen } \\ 106 & \text { Elementaire technische beroepen } \\ 108 & \text { Elementaire transportberoepen } \\ 112 & \text { Elementaire administratieve, commerciële beroepen } \\ 117 & \text { Elementaire verzorgende beroepen } \\ \mathbf{2 1} & \text { LAGERE NIET-SPECIALISTISCHE BEROEPEN }\end{aligned}$

211 Lagere niet-specialistische beroepen

\section{LAGERE DOCENTEN SPORTVAKKEN}

234 Lagere docenten sportvakken

\section{LAGERE AGRARISCHE BEROEPEN}

Lagere algemeen agrarische beroepen

$243 \quad$ Lagere technisch-agrarische beroepen

\section{LAGERE WISKUNDIGE, NATUURWETENSCHAPPELIJKE BEROEPEN}

251 Lagere wiskundige, natuurwetenschappelijke beroepen

$\begin{aligned} 26 & \text { LAGERE TECHNISCHE BEROEPEN } \\ 261 & \text { Lagere technische beroepen (ongeacht specialis } \\ 262 & \text { Lagere bouwkundige beroepen } \\ 263 & \text { Lagere weg- en waterbouwkundige beroepen } \\ 264 & \text { Lagere metalkundige beroepen } \\ 265 & \text { Lagere werktuigbouwkundige beroepen } \\ 267 & \text { Lagere elektrotechnische beroepen } \\ 268 & \text { Lagere grafische beroepen } \\ 271 & \text { Lagere procestechnische beroepen } \\ 272 & \text { Lagere technische beroepen NEG }\end{aligned}$

\section{LAGERE TRANSPORTBEROEPEN}

282 Lagere algemene transportberoepen
Kantoorhulpen, inpakkers en colporteurs

Agrarische hulparbeiders

Productiemedewerkers

Laders en lossers

Vakkenvullers

Interieurverzorgers

Ondersteunende administratieve hulpkrachten

Zweminstructeurs

Agrarische arbeiders

Landbouwmachinebestuurders en vissers

Laboratorium-assistenten

Conciërges

Bouwvakkers

Weg- en waterbouwkundige arbeiders

Metaalarbeiders

Assembleurs

Monteurs en controleurs elektrotechnische producten

Grafisch productiepersoneel

Mechanisch operators

Confectie-arbeiders

Chauffeurs 
Beroepsgroepen, volgens SBC '92 (vervolg)

\begin{tabular}{|c|c|c|}
\hline Nr. & SBC Beroepsklasse Beroepsgroep (CBS-naam) & Beroepsgroep (ROA-naam) \\
\hline 29 & LAGERE (PARA)MEDISCHE BEROEPEN & \\
\hline 292 & Lagere (para)medische beroepen & Verpleeghulpen en leerling-verpleegkundigen \\
\hline 31 & LAGERE ADMINISTRATIEVE, COMMERCIËLE BEROEPEN ED & \\
\hline 315 & Lagere administratieve beroepen & Receptionisten en administratieve employés \\
\hline 316 & Lagere (technisch-)commerciële beroepen & Verzekeringsagenten \\
\hline 317 & Lagere verkoopberoepen & Verkopers \\
\hline 33 & LAGERE BEVEILIGINGSBEROEPEN & \\
\hline 342 & Lagere beveiligingsberoepen & Aspirant politieagenten, soldaten en beveiligingshulpkrachten \\
\hline 37 & LAGERE VERZORGENDE BEROEPEN & \\
\hline 372 & Lagere algemeen verzorgende beroepen e.d. & Hulpkrachten horeca en verzorging \\
\hline 373 & Lagere commercieel-verzorgende beroepen & Café- en snackbarhouders \\
\hline 42 & MIDDELBARE DOCENTEN TRANSPORT-, SPORTVAKKEN & \\
\hline 427 & Middelbare docenten transportvakken & Rij-instructeurs \\
\hline 434 & Middelbare docenten sportvakken & Sportinstructeurs \\
\hline 44 & MIDDELBARE AGRARISCHE BEROEPEN & \\
\hline 442 & Middelbare (technisch-) agrarische beroepen & Agrarische vakkrachten \\
\hline 444 & Middelbare commercieel-agrarische beroepen & Agrarische bedrijfshoofden \\
\hline 45 & MIDDELBARE WISKUNDIGE, NATUURWETENSCHAPPELIJKE BEROEPEN & \\
\hline 451 & Middelbare wiskundige, natuurwetenschappelijke beroepen & Laboranten \\
\hline 46 & MIDDELBARE TECHNISCHE BEROEPEN & \\
\hline 461 & Middelbare technische beroepen (ongeacht specialisatie) & Hoofden technische dienst \\
\hline 462 & Middelbare bouwkundige beroepen & Aannemers en installateurs \\
\hline 463 & Middelbare weg- en waterbouwkundige beroepen & Weg- en waterbouwkundige vakkrachten \\
\hline 464 & Middelbare metaalkundige beroepen & Bankwerkers en lassers \\
\hline 465 & Middelbare werktuigbouwkundige beroepen e.d. & Monteurs \\
\hline 466 & Middelbare elektrotechnische beroepen (automatisering e.d.) & Elektronicamonteurs \\
\hline
\end{tabular}


Beroepsgroepen, volgens SBC '92 (vervolg)

\begin{tabular}{|c|c|c|}
\hline Nr. & SBC Beroepsklasse Beroepsgroep (CBS-naam) & Beroepsgroep (ROA-naam) \\
\hline 467 & Middelbare elektrotechnische beroepen (excl. automatisering) & Elektromonteurs \\
\hline 468 & Middelbare grafische beroepen e.d. & Grafische vakkrachten \\
\hline $471 a$ & Middelbare procestechnische beroepen & Procesoperators \\
\hline $471 \mathrm{~b}$ & Middelbare procestechnische beroepen & Bakkers en slagers \\
\hline 472 & Middelbare technische beroepen NEG & Schoen- en kleermakers \\
\hline 473 & Middelbare technische beveiligingsberoepen & Brandweerlieden \\
\hline 48 & MIDDELBARE TRANSPORTBEROEPEN ED & \\
\hline 482 & Middelbare algemene transportberoepen & Schippers en conducteurs \\
\hline 484 & Middelbare economisch-administratieve transportberoepen & Administratieve transportemployés \\
\hline 485 & Middelbare verzorgende transportberoepen & Stewards \\
\hline 49 & MIDDELBARE (PARA)MEDISCHE BEROEPEN & \\
\hline 492 & Middelbare algemene (para)medische beroepen & Verplegenden en doktersassistenten \\
\hline 493 & Middelbare technisch-(para)medische beroepen & Apothekersassistenten en medisch laboranten \\
\hline 494 & Middelbare economisch-administratieve (para)medische beroepen & Medisch secretaresses \\
\hline 495 & Middelbare verzorgend-(para)medische beroepen & Ziekenverzorgenden \\
\hline 51 & MIDDELBARE ADMINISTRATIEVE, COMMERCIËLE BEROEPEN ED & \\
\hline 513 & Middelbare bedriifskundige beroepen & Productieplanners \\
\hline 514 & Middelbare administratieve beroepen (automatisering e.d.) & Programmeurs \\
\hline 515 & Middelbare administratieve beroepen (excl. automatiering) & Boekhouders en secretaresses \\
\hline 516 & Middelbare commerciële beroepen & Commercieel employés \\
\hline 517 & Middelbare verkoopberoepen & Winkeliers \\
\hline 521 & Middelbare technisch-, wiskundig-, commerciële, administratieve beroepen & Technisch-commercieel employés \\
\hline 53 & MIDDELBARE JURIDISCHE, BESTUURLIJKE BEVEILIGINGSBEROEPEN & \\
\hline 532 & Middelbare juridische, bestuurlijke beroepen & Juridisch en fiscaal medewerkers \\
\hline 542 & Middelbare beveiligingsberoepen & Politieagenten, onderofficieren en beveiligingsemployés \\
\hline 55 & MIDDELBARE TAALKUNDIGE, CULTURELE BEROEPEN & \\
\hline 553 & Middelbare taalkundige beroepen e.d. & Bibliotheekassistenten \\
\hline 554 & Middelbare kunstzinnige beroepen & Grafisch ontwerpers \\
\hline
\end{tabular}


Beroepsgroepen, volgens SBC '92 (vervolg)

Nr. $\quad$ SBC Beroepsklasse Beroepsgroep (CBS-naam)

Beroepsgroep (ROA-naam)

56 MIDDELBARE BEROEPEN M.B.T. GEDRAG EN MAATSCHAPPI

563 Middelbare sociaal-maatschappelijke beroepen e.d.

\section{MIDDELBARE VERZORGENDE BEROEPEN ED.}

Middelbare algemeen verzorgende beroepen

573 Middelbare commercieel-verzorgende beroepen e.d.

\section{HOGERE PEDAGOGISCHE BEROEPEN}

621 Hogere pedagogische beroepen (ongeacht specialisatie)

622 Hogere onderwijskundige, pedagogische beroepen

623 Docenten basisonderwijs, algemeen vormende vakken

625 Docenten exacte, (para)medische, verzorgende vakken $\left(2^{\mathrm{e}}\right.$ en $3^{\mathrm{e}} \mathrm{gr}$.)

626 Docenten agrarische, technische, transportvakken $\left(2^{\mathrm{e}}\right.$ en $3^{\mathrm{e}} \mathrm{gr}$.)

631 Docenten economische, administratieve, juridische vakken $\left(2^{\mathrm{e}}\right.$ en $3^{\mathrm{e}} \mathrm{gr}$.)

633 Docenten taalkundige, culturele vakken e.d.

$634 \quad$ Docenten sociale, psychologische vakken $\left(2^{\mathrm{e}}\right.$ en $3^{\mathrm{e}} \mathrm{gr}$. $)$

64 HOGERE LANDBOUWKUNDIGE BEROEPEN

$642 \quad$ Hogere landbouwkundige berOepen

\section{HOGERE WISKUNDIGE, NATUURWETENSCHAPPELIJKE BEROEPEN}

651 Hogere wiskundige, natuurwetenschappelijke beroepen

66 HOGERE TECHNISCHE BEROEPEN

662 Hogere bouwkundigen, technische

beveiligingsberoepen

Hogere weg-en waterbouwkundigen

Hogere metaalkundige beroepen

Hogere werktuigbouwkundige beroepen e.d.

Hogere elektrotechnische beroepen (automatisering e.d.)

Hogere elektrotechnische beroepen (excl. Automatisering)

Hogere procestechnische beroepen e.d.
Activiteitenbegeleiders en medewerkers arbeidsbemiddeling

Verzorgend personeel

Bedrijfshoofden horeca

Docenten $2^{\mathrm{e}}$ en $3^{\mathrm{e}}$ graads zonder specialisatie

Onderwijskundig medewerkers

Leraar basisonderwijs

Docenten exacte, medische en verzorgende vakken $\left(1^{\mathrm{e}} \mathrm{gr}\right.$.)

Docenten landbouw en techniek ( $2^{\mathrm{e}} \mathrm{gr}$.)

Docenten economisch-administratieve vakken $\left(1^{\mathrm{e}} \mathrm{gr}\right.$.

Docenten talen en expressie

Docenten sociale vakken $\left(1^{\mathrm{e}} \mathrm{gr}\right.$.)

Milieuhygiënisten en agrarisch vertegenwoordigers

Technisch analisten

Architecten en bouwkundig projectleiders

Weg- en waterbouwkundig ontwerpers en projectleiders

Bedrijfshoofden metaalbewerking

Werktuigbouwkundig ontwerpers en hoofden technische dienst

Technisch systeemanalisten

Elektrotechnisch ontwerpers en bedrijfshoofden

Procestechnologen 
Beroepsgroepen, volgens SBC '92 (vervolg)

\begin{aligned} Nr. & SBC Beroepsklasse Beroepsgroep (CBS-naam) \\ \hline 68 & HOGERE TRANSPORTBEROEPEN \\ 682 & Hogere transportberoepen (excl. Technisch) \\ 69 & HOGERE (PARA)MEDISCHE BEROEPEN \\ 692 & Hogere algemene, verzorgende (para)medische beroepen \\ 693 & Hogere technisch-(para)medische beroepen \\ 71 & HOGERE ADMINISTRATIEVE, COMMERCIËLE, ECONOMISCHE BEROEPEN \\ 712 & Hogere algemeen economische beroepen \\ 713 & Hogere bedrijfsundige beroepen e.d. \\ 714 & Hogere administratieve beroepen (automatisering e.d.) \\ 715 & Hogere administratieve beroepen (excl. Automatisering) \\ 716 & Hogere commerciële beroepen e.d. \\ 721 & Hogere technisch-, wiskundig-commerciële, administratieve beroepen \\ 73 & HOGERE JURIDISCHE, BESTUURLIJKE, BEVEILIGINGSBEROEPEN \\ 732 & Hogere juridische, besturlijke beroepen \\ 742 & Hogere algemene beveiligingsberoepen \\ 75 & HOGERE TAALKUNDIGE, CULTURELE BEROEPEN \\ 752 & Hogere taalkundige beroepen \\ 753 & Hogere bibliotheek-, documentatieberoepen \\ 754 & Hogere kunstzinnige beroepen \\ 76 & HOGERE BEROEPEN M.B.T. GEDRAG EN MAATSCHAPPIJ ED. \\ 762 & Hogere theologische beroepen \\ 763 & Hogere sociaal-maatschappelijke beroepen \\ 764 & Hogere beroepen in de journalistiek \\ 765 & Hogere sociaal-wetenschappelijke beroepen e.d. \\ 77 & HOGERE VERZORGENDE BEROEPEN \\ 772 & Hogere verzorgende beroepen \\ & \end{aligned}

Beroepsgroep (ROA-naam)

Vliegers, scheepskapiteins en leidinggevenden transport

Therapeuten en verpleegkundigen

Medisch analisten

Bedrijfshoofden

Organisatie-adviseurs

Systeemanalisten

Assistent accountants

Commercieel medewerkers

Technisch-bedrijfskundig medewerkers

Juridisch, bestuurlijk medewerkers

Politie-inspecteurs en officieren

Tolken, vertalers en schrijvers

Bibliothecarissen

Kunstenaars

Geestelijk verzorgers

Sociaal-cultureel werkers

Journalisten

Sociaal-wetenschappelijk medewerkers

Afdelingshoofden zorginstelling 
Beroepsgroepen, volgens SBC '92 (vervolg)

Nr. $\quad$ SBC Beroepsklasse Beroepsgroep (CBS-naam)

Beroepsgroep (ROA-naam)

78 MANAGERS (HBO WERK- EN DENKNIVEAU) ED.

788 Managers (HBO werk- en denkniveau) e.d.

Leidinggevenden

82 WETENSCHAPPELIJKE PEDAGOGISCHE BEROEPEN

Wetenschappelijke pedagogische beroepen (ongeacht specialisatie)

Wetenschappelijke onderwijskundige, pedagogische beroepen

Docenten exacte, (para)medische, verzorgende vakken $\left(1^{\mathrm{e}} \mathrm{gr}\right.$. en WO

Docenten agrarische, technische, transportvakken $\left(1^{\mathrm{e}}\right.$ gr. en WO

Docenten economische, administratieve, juridische vakken $\left(1^{\mathrm{e}} \mathrm{gr}\right.$. en WO)

Docenten taalkundige, culturele vakken $\left(1^{\mathrm{e}}\right.$ gr. en WO)

Docenten sociale, psychologische vakken ( $1^{\mathrm{e}} \mathrm{gr}$. en WO)

WETENSCHAPPELIJKE LANDBOUWKUNDIGE BEROEPEN

842 Wetenschappelijke landbouwkundige beroepen

Oocent 1 graads zonder specialisat

Docenten exacte, medische en verzorgende vakken $\left(1^{\mathrm{e}} \mathrm{gr}.\right)$

Docenten landbouw en techniek $\left(2^{\mathrm{e}} \mathrm{gr}\right.$.)

Docenten economisch-administratieve vakken $\left(1^{\mathrm{e}} \mathrm{gr}\right.$.

Docenten letteren $\left(1^{\mathrm{e}} \mathrm{gr}\right.$.

Docenten sociale vakken $\left(1^{\mathrm{e}} \mathrm{gr}\right.$.

Landbouwkundigen

WETENSCH. WISKUNDIGE, NATUURWETENSCHAPPELIJKE BEROEPEN

Wetenschappelijke wiskundige, natuurwetenschappelijke beroepen

Natuurwetenschappers

\section{BEROEPEN}

Wetenschappelijke technische (ongeacht specialisatie), beroepen

Wetenschappelijke administratieve beroepen (automatisering e.d.)

Wetenschappelijke administratieve beroepen (excl. automatisering

Informatici

Accountants

WETENSCHAPPELIJKE JURIDISCHE, BESTUURLIJKE BEROEPEN

Werktuigbouwkundige beroepen

Wetenschappelijke (weg- en waterbouw-)bouwkundige beroepen e.d.

Wetenschappelijke elektrotechnische beroepen

Wetenschappelijke materiaalkundige, procestechnische beroepen e.d.

WETENSCHAPPELIJKE (PARA)MEDISCHE BEROEPEN ED.

Wetenschappelijke (para)medische beroepen (excl. technisch)

Wetenschappelijke technisch (para)medische beroepen

\section{Werktuigbouwkundigen}

(Weg-en water)bouwkundigen

Elektrotechnici

Materiaalkundigen

Artsen

Apothekers 
Beroepsgroepen, volgens SBC '92 (vervolg)

\begin{tabular}{rll} 
Nr. & SBC Beroepsklasse Beroepsgroep (CBS-naam) & Beroepsgroep (ROA-naam) \\
\hline 91 & WETENSCHAPPELIJKE ECONOMISCHE, ADMINISTRATIEVE BEROEPEN ED. & \\
912 & Wetenschappelijke algemeen-economische, commerciële beroepen e.d. & Economen \\
913 & Wetenschappelijke (technisch-) bedrijfskundige, wiskundig-economische EPEN & Juristen \\
932 & Wetenschappelijke juridische, bestuurlijke beroepen & \\
& & \\
96 & WETENSCHAPPELIJKE BEROEPEN M.B.T. GEDRAG EN MAATSCHAPPIJ & Geestelijken \\
962 & Wetenschappelijke theologische beroepen & Sociale raadslieden en hoofden personeelszaken \\
963 & Wetenschappelijke sociaal-maatschappelijke beroepen & Taalkundigen \\
964 & Wetenschappelijke journalistieke, taalkundige, culturele beroepen & Sociaal-wetenschappelijk onderzoekers \\
965 & Wetenschappelijke sociaal-wetenschappelijke beroepen & \\
98 & MANAGERS (WETENSCHAPPELIJK WERK- EN DENKNIVEAU) & Managers \\
988 & Managers (wetenschappelijk werk- en denkniveau) & \\
\hline
\end{tabular}




\section{Beknopte Bedrijfsclassificatie SBI '93}

\begin{tabular}{|c|c|c|}
\hline $\mathrm{Nr}$. & Bedrijfssector & SBI '93 \\
\hline 1. & Landbouw en visserij & 01000-02999, 05000-05999 \\
\hline 2. & Voeding & $15000-16999$ \\
\hline 3. & Chemie & $24000-25999$ \\
\hline 4. & Metaal en elektrotechniek & $27000-36099,36200-36599,36700-36999$ \\
\hline 5. & Overige industrie & $17000-22999,26000-26999,36100-36199,36600-36699$ \\
\hline 6. & Energie & $\begin{array}{l}10000-11999,14000-14999 \\
23000-23999,40000-41999\end{array}$ \\
\hline 7. & Bouw en onroerend goed & $45000-45999,70000-70999$ \\
\hline 8. & Handel en reparatie & $50000-50402,50500-54999$ \\
\hline 9. & Transport en communicatie & $60000-64999$ \\
\hline 10. & Bank- en verzekeringswezen & $65000-67999$ \\
\hline 11. & Horeca en zakelijke dienstverlening & $\begin{array}{l}55000-55999,71000-72999 \\
74000-74999,90000-90999 \\
92400-92799,93000-95999\end{array}$ \\
\hline 12. & Kwartaire diensten & $\begin{array}{l}73000-73999,85000-85999 \\
91000-91999,92000-92399\end{array}$ \\
\hline 13. & Overheid en onderwijs & $\begin{array}{l}75000-75999,80000-80999, \\
99000-99500\end{array}$ \\
\hline
\end{tabular}




\section{Uitgebreide Bedrijfsclassificatie SBI '93}

\begin{tabular}{|c|c|c|}
\hline Nr. & Bedrijfssector & SBI '93 \\
\hline 1. & Tuinbouw & 01120-01199 \\
\hline 2. & Veehouderij & 01200-01599 \\
\hline 3. & Akkerbouw, bosbouw en visserij & $\begin{array}{l}\text { 00001-01119, 02000-02999, } \\
05000-05999\end{array}$ \\
\hline 4. & Vlees- en visverwerking & $15000-15299$ \\
\hline 5. & Overige voedingsproducten & $15300-15899$ \\
\hline 6. & Drank en tabaksproducten & $15900-16999$ \\
\hline 7. & Basischemie & $24000-24199$ \\
\hline 8. & Eindproducten chemie & $24200-24999$ \\
\hline 9. & Kunststofverwerking & $25000-25999$ \\
\hline 10. & Basismetaal & $27000-27999$ \\
\hline 11. & Metaalproducten & $\begin{array}{l}28000-28999,36000-36099 \\
36200-36599,36700-36999\end{array}$ \\
\hline 12. & Machine-industrie & $29000-29999$ \\
\hline 13. & Elektrotechniek & $30000-33999$ \\
\hline 14. & Transportmiddelen & $34000-35999$ \\
\hline 15. & Textiel & $17000-19999$ \\
\hline 16. & Hout- en bouwmaterialen & $\begin{array}{l}20000-20999,26000-26999 \\
36100-36199,36600-36699\end{array}$ \\
\hline 17. & Papier & $21000-21999$ \\
\hline 18. & Grafische industrie & $22000-22999$ \\
\hline 19. & Energie & $\begin{array}{l}10000-11999,14000-14999 \\
23000-23999,40000-41999\end{array}$ \\
\hline 20. & Bouw & $45000-45999$ \\
\hline 21. & Exploitatie van onroerend goed & $70000-70999$ \\
\hline 22. & Handel en reparatie & $50000-50402,50500-52999$ \\
\hline 23. & Scheep- en luchtvaart & $61000-62999$ \\
\hline 24. & Weg- en railvervoer & $60000-60999,63000-63999$ \\
\hline 25. & Communicatie & $64000-64999$ \\
\hline 26. & Bankwezen & $65000-65999,67000-67199$ \\
\hline 27. & Verzekeringswezen & $66000-66999,67200-67999$ \\
\hline 28. & Horeca & $55000-55999$ \\
\hline 29. & Zakelijke dienstverlening & $71000-72999,74000-74999$ \\
\hline 30. & Overige commerciële dienstverlening & $\begin{array}{l}90000-90999,92400-92799 \\
93000-95999\end{array}$ \\
\hline 31. & Gezondheidszorg & $85000-85999$ \\
\hline 32. & Overige kwartaire diensten & $\begin{array}{l}73000-73999,91000-91999 \\
92000-92399\end{array}$ \\
\hline 33. & Onderwijs & $80000-80999$ \\
\hline 34. & Overheid & $75000-75999,99000-99500$ \\
\hline
\end{tabular}

